\title{
15. LOWER CRETACEOUS RADIOLARIAN BIOSTRATIGRAPHY AND BIOGEOGRAPHY OFF NORTHWESTERN AUSTRALIA (ODP SITES 765 AND 766 AND DSDP SITE 261), ARGO ABYSSAL PLAIN AND LOWER EXMOUTH PLATEAU ${ }^{1}$
}

\author{
Peter O. Baumgartner ${ }^{2}$
}

\begin{abstract}
During Leg 123, abundant and well-preserved Neocomian radiolarians were recovered at Site 765 (Argo Abyssal Plain) and Site 766 (lower Exmouth Plateau). The assemblages are characterized by a scarcity or absence of Tethyan taxa. The Berriasian-early Aptian radiolarian record recovered at Site 765 is unique in its density of well-preserved samples and in its faunal contents. Remarkable contrasts exist between radiolarian assemblages extracted from claystones of Site 765 and reexamined DSDP Site 261, and faunas recovered from radiolarian sand layers of Site 765 . Clay faunas are unusual in their low diversity of apparently ecologically tolerant species, whereas sand faunas are dominated by non-Tethyan species that have never been reported before. Comparisons with Sites 766 and 261, as well as sedimentological observations, lead to the conclusion that this faunal contrast results from a difference in provenance, rather than from hydraulic sorting.

Biostratigraphic dating proved difficult principally because of the paucity or even absence of (Tethyan) species used in published zonations. In addition, published zonations are contradictory and do not reflect total ranges of species.

Radiolarian assemblages recovered from claystones at Sites 765 and 261 in the Argo Basin reflect restricted oceanic conditions for the latest Jurassic to Barremian time period. Neither the sedimentary facies nor the faunal associations bear any resemblance to sediment and radiolarian facies observed in typical Tethyan sequences. I conclude that the Argo Basin was paleoceanographically separated from Tethys during the Late Jurassic and part of the Early Cretaceous by its position at a higher paleolatitude and by enclosing landmasses, i.e., northeastern India and the Shillong Block, which were adjacent to the northwestern Australian margin before the opening.

Assemblages recovered from radiolarian sand layers are dominated by non-Tethyan species that are interpreted as circumantarctic. Their sudden appearance in the late Berriasian/early Valanginian pre-dates the oceanization of the Indo-Australian break-up (M11, late Valanginian) by about 5 m.y., but coincides with a sharp increase in margin-derived pelagic turbidites. The Indo-Australian rift zone and its adjacent margins probably were submerged deeply enough to allow an intermittent "spillover" of circumantarctic cold water into the Argo Basin, creating increased bottom current activity. Circumantarctic cold-water radiolarians transported into the Argo Basin upwelled along the margin and died en masse. Concomitant winnowing by bottom currents led to their accumulation in distinct radiolarite layers. High rates of faunal change and the sharp increase of bottom current activity are thought to be synchronous with the two pronounced late Berriasian-early Valanginian lowstands in sea level. Hypothetically, both phenomena might have been caused by a glaciation on the Antarctic-Australian continent, which was for the first time isolated from the rest of Gondwana by oceanic seaways as a result of Jurassic and Early Cretaceous seafloor spreading.

The absence of typical Tethyan radiolarian species during the late Valanginian to late Hauterivian period is interpreted as reflecting a time of strong influx of circumantarctic cold water following oceanization (M11) and rapid spreading between southeast India and western Australia.

The reappearance and gradual increase in abundance and diversity of Tethyan forms along with the still dominant circumantarctic species are thought to result from overall more equitable climatic conditions during the Barremian and early Aptian and may have resulted from the establishment of an oceanic connection with the Tethys Ocean during the early Aptian.
\end{abstract}

\section{INTRODUCTION}

During Legs 122 and 123 of the Ocean Drilling Program, scientists drilled two transects across the northwestern Australian margin (Fig. 1) to explore what was thought to be a remnant of a north Gondwanian margin facing the Jurassic Tethys Ocean. Oxfordian (M26) oceanic crust, a remnant of ancient ocean floor older than any previously drilled in the Indian Ocean, was expected to underlie Upper Jurassic sediments at Site 765 in the Argo Abyssal Plain. The Mesozoic sediment column was supposed to be similar to Tethyan ones exposed in the Alpine-Himalayan mountain belt. Surprisingly, no fossils proving the presence of Jurassic sediments were found; volcanic basement at Site 765 is now thought to be of Tithonian or older age, mainly based on

\footnotetext{
1 Gradstein, F. M., Ludden, J. N., et al., 1992. Proc. ODP, Sci. Resuits, 123: College Station, TX (Ocean Drilling Program).

2 Institut de Géologie, BFSH2, CH-1015 Lausanne, Switzerland.
}

correlation of a poorly preserved nannoflora found in the lowest core with one at DSDP Site 261 (Dumoulin and Bown, this volume). Both the relatively young age of ocean crust and the Cretaceous sedimentary facies, dominated by clays, point to major dissimilarities between a Tethyan and the northwestern Australian margin. A Latest Jurassic or Earliest Cretaceous age for Argo Abyssal Plain oceanic basement at Site 765 necessitates reevaluation of published reconstructions of the late Mesozoic tectonic history of the northwestern Australian margin and adjacent parts of the Indian Ocean.

The biogenic components of the recovered sediments, particularly the radiolarians, provide important information about possible links of the studied area with the Tethys Ocean or, alternatively, with another oceanic area. Microfossil assemblages recovered from Sites 765 and 766 show significant differences in abundance, diversity, and stratigraphic range with respect to "normal" Tethyan sequences (Ludden, Gradstein, et al., 1990). Abundant and well-preserved Neocomian radiolarians recovered at Sites 765 and 766 are characterized by a scarcity of Tethyan taxa, 


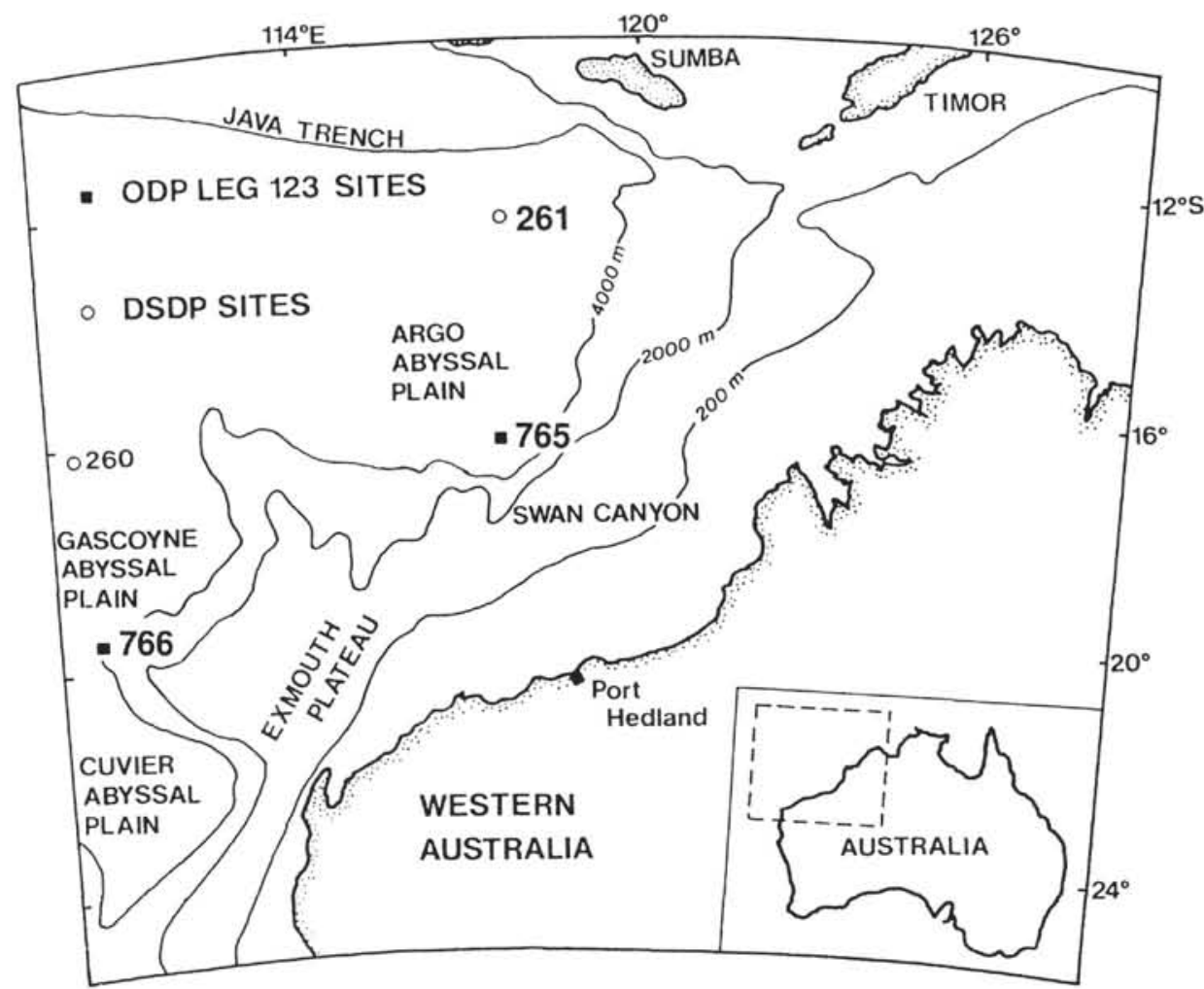

Figure 1. Geography of northwestern Australia and surrounding ocean basins and location of Leg 123 sites (rectangles) and DSDP Leg 27 sites (open circles).

even their near-total absence in part of the section. Remarkable contrasts also exist between radiolarian assemblages preserved in claystones of Site 765 and reexamined DSDP Site 261 and faunas recovered from radiolarian sand layers of Site 765 .

Hemipelagic-pelagic claystones contain scarce, well-preserved radiolarian assemblages of very low diversity that are identical at both Sites 765 and 261 . In contrast, current-deposited radiolarian sand layers ("radiolarites") of Site 765 contain abundant radiolarians that make up low-diversity assemblages dominated by a few species. These species, all unknown from Tethys, appear and disappear rapidly and show remarkably short-lived acmes. These current-deposited assemblages are almost absent from the more distal Site 261, but can be found at Site 766 (lower Exmouth Plateau), despite a prevailing clastic sedimentation.

In this chapter, I document and interpret this unusual radiolarian record. This study should provide key data for reconstructing the Argo Basin paleoceanography. Because paleoceanography is a function of paleolatitude, paleoclimate, and ancient plate-tectonic settings, these data and their interpretation also will result in constraints to reconstructions of plate tectonics of Gondwanaland (see Baumgartner et al., this volume).

The sedimentological observations and conclusions reported here were made in close collaboration with Jean Marcoux, Julie Dumoulin, and other shipboard scientists.

\section{SCOPE AND METHODS}

\section{Scope of Chapter}

\section{Biochronology}

This study documents the biostratigraphic information contained in the radiolarian assemblages from ODP Sites 765 and 766 and preliminary data from DSDP Site 261. While correlation among sites seems possible, interpretation in terms of radiolarian biochronology established elsewhere meets significant difficulties. First, this is because of the paucity or absence of radiolarian species known from other (especially Tethyan) areas, where radiolarian biostratigraphy has been developed in past years. Second, this is because no standard radiolarian zonation for the Lower Cretaceous is currently available. Two published zonations (Schaaf, 1985; Sanfilippo and Riedel, 1985), based on probabilistic concepts, are in conflict with actual sample data (for discussion, see Baumgartner, 1984a). In addition, the two proposed range charts contradict each other. Work in progress in our group (Jud, 1988) shows that most radiolarian ranges are longer than probabilistic approaches have previously shown. As a consequence, application of the above zonations results in conflicting associations or simply in wrong age designations.

In the following chapter, first and final occurrences of taxa used in published zonations are discussed for each site and then interpreted in terms of age. However, one should be aware of the preliminary nature of such "dating." Inconsistencies among ages based on the published radiolarian zonations and those obtained from nannofossils and palynomorphs clearly show the deficiency of existing radiolarian zonations. In addition, the near-total absence of Tethyan taxa in the Valanginian-Hauterivian part of the sections creates truncated ranges for some species, resulting in later first occurrences here than observed elsewhere.

Ranges for each species are given in the "Taxonomic Listing" section (this chapter); published ranges are compared with apparent ranges in the Indian Ocean, which are based on ages stated in the Leg 123 magnetobiostratigraphic synthesis (Kaminski et al., this volume).

\section{Taxon Quantitative Analysis}

The following taxon quantitative analysis demonstrates the presence of different radiolarian faunal communities that were brought together and interlayered by sedimentary and pale- 
oceanographic processes. The correlation of lithologic change, sedimentary structures, and radiolarian faunal change permits sound paleoceanographic interpretations.

Quantitative faunal composition of all sedimentary radiolarian assemblages, especially current-deposited ones, is a function of the hydraulic conditions under which the assemblages were deposited. Size sorting and/or bulk density sorting affect, and perhaps determine, the quantitative composition of an assemblage. Therefore, the effect of sedimentology on the original faunal signal should be discussed. However, hydraulic phenomena are almost never $100 \%$ efficient. For example, "clay faunas" should contain traces of species normally found in "sand faunas" were their separation merely from hydraulic sorting. In addition, the bottom current history (as recorded by the presence of radiolarian sand layers and the "exotic" character of the radiolarians) may have a common paleoceanographic cause, as presented in the interpretations.

\section{Preparation of Radiolarian Residues and Data Acquisition}

\section{Sample Selection}

All samples were selected by visual examination of the core with a hand lens or a binocular microscope, which allows one to estimate abundance and general preservation. In the Cretaceous clay-rich sequences of Site 765 , both sandy layers and claystones were sampled. Many radiolarian samples were taken from sandy laminae and layers that showed the least detrital content. The claystones of Sites 765 and 261 often contain rare, but well-preserved, radiolarians, which are felt as little sand grains when scratching the core surface. Visual examination of a freshly cleaned surface of the core shows well-preserved radiolarians as white specks. The dark-colored, predominantly detrital lithologies recovered at Site 766 presented some problems for radiolarian sample selection. Fine-grained, apparently less detrital lithologies were more commonly selected. However, radiolarian abundance and preservation is generally lower than at Site 765 for the same stratigraphic intervals.

\section{Sample Preparation}

All samples recovered during Leg 123 and those sampled at the West Coast Repository from the cores of Site 261 were crushed into millimeter-sized pieces and then boiled in a mixture of hydrogen peroxide and Calgon for 5 to $20 \mathrm{~min}$. Concentrations varied, depending on the degree of induration of the sediment. Lime-rich, lithified samples were first decalcified in a $20 \%$ hydrochloric acid solution. However, this procedure was avoided whenever possible to preserve scattered calcified radiolarians, foraminifers, and other sand-sized carbonate particles. The samples then were sieved, and the fraction $>44 \mathrm{~mm}$ was analyzed. Some heavily silicified samples (Site 766) would not disaggregate with the above processes and had to be digested for $24 \mathrm{hr}$ in a $5 \%$ hydrofluoric acid solution, then thoroughly washed and sieved.

\section{Observation and Estimation of General Abundance and Preservation in all Prepared Residues}

The skeletons of most recovered Mesozoic radiolarians have been recrystallized as quartz or clay minerals, are filled by matrix or cement, and thus could not be examined using standard transmitted-light techniques. These residues were sieved, dried, and examined using reflected-light methods and scanning electron microscopy (SEM).

Bulk abundances of radiolarians given in this chapter (Tables 1 through 5) are based on sieved residues and, consequently, may differ markedly from the lithologic descriptions, which were based on smear slide data. Cluster analysis of smear slide data and estimates of radiolarian abundance from residues nevertheless harmonize well (Fig. 2). Estimates of abundance are qualitative and were determined on the visual approximation of the total amount of residue per $10 \mathrm{~cm}^{3}$ of sediment and of the percentage of radiolarian specimens observed in this residue per picking tray. Abundance has been defined as follows:

A (abundant $)=>2 \mathrm{~cm}^{3}$ of residue, $>80 \%$ radiolarians. Numerical value $=5$.

$C($ common $)=0.2-2 \mathrm{~cm}^{3}$ of residue, $10 \%-80 \%$ radiolarians. Numerical value $=4$.

$\mathrm{F}(\mathrm{few})=0.2-2 \mathrm{~cm}^{3}$ of residue, $1 \%-10 \%$ radiolarians. Numerical value $=3$.

$\mathrm{R}$ (rare) $=0.2-2 \mathrm{~cm}^{3}$ of residue, $<1 \%$ radiolarians. Numerical value $=2$.

VR $\left(\right.$ very rare) $=0.2-2 \mathrm{~cm}^{3}$ of residue, $<0.1 \%$ radiolarians. Numerical value $=1$.

- $($ barren $)=$ No radiolarians in at least one entire slide or picking tray. Numerical value $=0$.

Radiolarian preservation ranges from very poor to very good. Degraded preservation is a result of recrystallization of opaline silica as quartz and/or replacement and overgrowth by clay minerals, zeolites, and so forth. Preservation was defined as follows:

VG $($ very good $)=$ Majority of specimens observed are complete, with spines intact, no overgrowths, or recrystallization. Nearly all specimens determinable. Numerical value $=5$.

$\mathrm{G}($ Good $)=$ Many specimens complete with spines intact, little or no overgrowths, cement or matrix infill occurs, but outer surface intact. Most specimens determinable. Numerical value $=4$

$\mathrm{M}$ (moderate $)=$ A substantial portion of the specimens broken, with some degree of overgrowth, etching, or replacement by minerals other than quartz or pyrite. $50 \%$ of specimens determinable. Numerical value $=3$.

$\mathrm{P}($ poor $)=$ Specimens mostly broken and fragmentary or strongly etched or replaced by other minerals. $<5 \%$ of specimens determinable. Numerical value $=2$.

VP $($ very poor $)=$ Specimens only present as inner molds or ghosts, or fragments. None determinable. Numerical value $=1$.

$($ not determinable $)=$ Numerical value $=0$.

\section{Methods for the Taxon-Quantitative Study}

The excellent preservation and density of radiolarian samples at Site 765 and the striking differences between radiolarian faunas preserved in clays and in sands called for a more quantitative method than those commonly used by Mesozoic radiolarian paleontologists. Radiolarian samples from land sections have to be disaggregated using hydrochloric and/or hydrofluoric acids because of considerable deep burial diagenesis. Consequently, the taxon quantitative composition of an original assemblage is altered not only by sedimentary and diagenetic processes, but also by selective etching, probably favoring the preservation of the more robust forms. The determination of taxon-specific abundances thus has been questioned in this kind of residue.

Unlike land-based samples, those from Sites 765 and 261 were washed with detergents only; thus, the obtained residue can be regarded as being close to the originally deposited assemblage. Estimates of abundances of taxon groups thus are more likely to reflect original radiolarian population variations than those of land-based samples.

Procedure: Two randomly strewn SEM stubs (12 mm diameter) were produced for each sample. The residues were first 
Table 1. Bulk abundance and preservation of radiolarians at Hole $765 \mathrm{C}$.

\begin{tabular}{|c|c|c|c|c|c|}
\hline $\begin{array}{l}\text { Core, section } \\
\text { interval }(\mathrm{cm})\end{array}$ & $\begin{array}{l}\text { Depth } \\
\text { (mbsf) }\end{array}$ & NA & NP & A & $\mathbf{P}$ \\
\hline $123-765 \mathrm{C}-2 \mathrm{R}-3,33-37$ & 362.93 & 0 & 0 & Barren & \\
\hline$-4 \mathrm{R}-3,110-112$ & 383.10 & 0 & 0 & Barren & \\
\hline$-6 \mathrm{R}-3,108-110$ & 402.38 & 1 & 1 & VR & VP \\
\hline$-9 \mathrm{R}-1,22-23$ & 427.52 & 0 & 0 & Barren & \\
\hline$-10 \mathrm{R}-4,57-61$ & 441.57 & 0 & 0 & Barren & \\
\hline$-11 R-4,111-113$ & 451.61 & 0 & 0 & Barren & \\
\hline$-11 \mathrm{R}-\mathrm{CC}$ & 451.91 & 2 & 2 & $\mathrm{R}$ & \\
\hline$-12 R-3,124-126$ & 459.44 & 0 & 0 & Barren & \\
\hline$-14 \mathrm{R}-1,44-45$ & 474.54 & 0 & 0 & Barren & \\
\hline$-14 \mathrm{R}-1,112-115$ & 475.22 & 0 & 0 & Barren & \\
\hline$-15 \mathrm{R}-1,13-15$ & 483.83 & 0 & 0 & Barren & \\
\hline$-15 R-1,104-109$ & 484.74 & 0 & 0 & Barren & \\
\hline$-16 R-3,129-131$ & 497.49 & 0 & 0 & Barren & \\
\hline$-17 \mathrm{R}-\mathrm{CC}$ & 507.98 & 0 & 0 & Barren & \\
\hline$-18 R-4,85-88$ & 517.25 & 0 & 0 & Barren & \\
\hline$-19 \mathrm{R}-1,76-78$ & 522.06 & 0 & 0 & Barren & \\
\hline$-20 \mathrm{R}-2,12-15$ & 532.42 & 2 & 1 & $\mathbf{R}$ & $\mathrm{P}$ \\
\hline$-20 \mathrm{R}-2,49-53$ & 532.79 & 0 & 0 & Barren & \\
\hline$-20 \mathrm{R}-\mathrm{CC}$ & 533.11 & 0 & 0 & Barren & \\
\hline$-21 \mathrm{R}-\mathrm{CC}$ & 540.91 & 4 & 2 & $\mathrm{C}$ & $\mathrm{P}$ \\
\hline$-22 R-2,37-41$ & 551.97 & 2 & 1 & $\mathrm{R}$ & P \\
\hline$-22 \mathrm{R}-\mathrm{CC}$ & 557.30 & 1 & 2 & VR & $P$ \\
\hline$-23 R-3,95-97$ & 563.65 & 0 & 0 & Barren & \\
\hline$-23 \mathrm{R}-\mathrm{CC}$ & 566.30 & 1 & 3 & VR & $\mathrm{M}$ \\
\hline$-24 \mathrm{R}-1$ & 569.30 & 1 & 3 & VR & $\mathrm{M}$ \\
\hline$-24 R-3,117-121$ & 573.47 & 0 & 0 & Barren & \\
\hline$-24 R-4,1-4$ & 573.81 & 0 & 0 & Barren & \\
\hline$-24 \mathrm{R}-4,106-109$ & 574.86 & 0 & 0 & Barren & \\
\hline$-24 \mathrm{R}-\mathrm{CC}$ & 574.89 & 0 & 0 & Barren & \\
\hline$-25 R-2,78-81$ & 581.28 & 0 & 0 & Barren & \\
\hline$-25 \mathrm{R}-3,87-91$ & 582.87 & 0 & 0 & Barren & \\
\hline$-25 \mathrm{R}-\mathrm{CC}$ & 585.55 & 0 & 0 & Barren & \\
\hline$-26 \mathrm{R}-4,0-4$ & 592.70 & 1 & 1 & VR & VP \\
\hline$-26 \mathrm{R}-5,41-44$ & 594.16 & 2 & 3 & $\mathrm{R}$ & $\mathrm{M}$ \\
\hline$-26 \mathrm{R}-\mathrm{CC}$ & 594.19 & 0 & 0 & Barren & \\
\hline$-27 \mathrm{R}-1,87-88$ & 598.37 & 1 & 3 & VR & $\mathrm{M}$ \\
\hline$-27 R-1,87-90$ & 598.38 & 2 & 4 & $\mathrm{R}$ & G \\
\hline$-27 \mathrm{R}-\mathrm{CC}$ & 599.93 & 0 & 0 & Barren & \\
\hline$-28 \mathrm{R}-1,107-108$ & 608.07 & 0 & 0 & Barren & \\
\hline$-28 \mathrm{R}-3,26-29$ & 610.33 & 0 & 0 & Barren & \\
\hline$-28 \mathrm{R}-\mathrm{CC}$ & 610.94 & 0 & 0 & Barren & \\
\hline$-29 \mathrm{R}-1,34-37$ & 616.74 & 0 & 0 & Barren & \\
\hline$-29 \mathrm{R}-3,89-92$ & 620.36 & 1 & 3 & VR & M \\
\hline$-29 R-4,82-86$ & 621.84 & 1 & 2 & VR & $\mathrm{P}$ \\
\hline$-29 \mathrm{R}-5,107-110$ & 623.69 & 0 & 0 & Barren & \\
\hline$-29 \mathrm{R}-\mathrm{CC}$ & 624.80 & 0 & 0 & Barren & \\
\hline$-30 \mathrm{R}-2,107-110$ & 628.46 & 0 & 0 & Barren & \\
\hline$-30 R-3,116-118$ & 630.01 & 2 & 3 & $\mathbf{R}$ & M \\
\hline$-30 R-4,46-49$ & 630.78 & 3 & 3 & $\mathrm{~F}$ & M \\
\hline$-30 \mathrm{R}-5,140-144$ & 633.21 & 0 & 0 & Barren & \\
\hline$-30 \mathrm{R}-6,88-92$ & 634.17 & 5 & 2 & A & $\mathrm{P}$ \\
\hline$-30 \mathrm{R}-\mathrm{CC}$ & 634.42 & 5 & 2 & A & $\mathrm{P}$ \\
\hline$-31 R-1,125-128$ & 636.55 & 5 & 3 & A & M \\
\hline$-31 R-2,101-104$ & 637.72 & 5 & 3 & A & M \\
\hline$-31 R-3,92-94$ & 639.10 & 4 & 3 & C & M \\
\hline$-31 \mathrm{R}-4,80-83$ & 640.41 & 2 & 3 & $\mathrm{R}$ & M \\
\hline$-31 \mathrm{R}-\mathrm{CC}$ & 640.71 & 5 & 2 & A & $\mathrm{P}$ \\
\hline$-32 R-1,65-68$ & 645.65 & 5 & 3 & A & $\mathrm{M}$ \\
\hline$-32 \mathrm{R}-2,133-137$ & 647.73 & 5 & 3 & A & M \\
\hline$-32 R-4,1-15$ & 649.41 & 5 & 3 & A & M \\
\hline$-32 \mathrm{R}-4,22-26$ & 649.35 & 5 & 3 & A & M \\
\hline$-32 \mathrm{R}-\mathrm{CC}$ & 649.43 & 5 & 2 & A & $\mathbf{P}$ \\
\hline$-33 \mathrm{R}-\mathrm{CC}$ & 658.08 & 3 & 2 & $\mathrm{~F}$ & $\mathbf{P}$ \\
\hline$-34 \mathrm{R}-\mathrm{CC}$ & 669.64 & 3 & 2 & $\mathrm{~F}$ & $\mathbf{P}$ \\
\hline$-35 \mathrm{R}-1,13-17$ & 674.23 & 1 & 3 & VR & M \\
\hline$-35 R-2,122-124$ & 676.82 & 0 & 0 & Barren & \\
\hline$-35 \mathrm{R}-3,46-50$ & 677.56 & 0 & 0 & Barren & \\
\hline$-35 R-4,49-53$ & 679.09 & 3 & 3 & F & M \\
\hline$-35 R-C C$ & 679.28 & 3 & 3 & $\mathrm{~F}$ & M \\
\hline$-36 R-2,5-8$ & 684.85 & 0 & 0 & Barren & \\
\hline$-36 \mathrm{R}-2,8-11$ & 684.88 & 1 & 1 & VR & VP \\
\hline$-36 \mathrm{R}-6,6-9$ & 690.86 & 2 & 3 & $\mathrm{R}$ & $\mathrm{M}$ \\
\hline$-36 \mathrm{R}-\mathrm{CC}$ & 692.40 & 2 & 2 & $\mathrm{R}$ & $\mathrm{P}$ \\
\hline$-37 R-1,64-65$ & 693.64 & 0 & 0 & Barren & \\
\hline$-37 R-1,95-97$ & 693.95 & 0 & 0 & Barren & \\
\hline$-37 \mathrm{R}-2,86-90$ & 695.36 & 0 & 0 & Barren & \\
\hline
\end{tabular}

Table 1 (continued)

\begin{tabular}{|c|c|c|c|c|c|}
\hline $\begin{array}{l}\text { Core, section } \\
\text { interval }(\mathrm{cm})\end{array}$ & $\begin{array}{l}\text { Depth } \\
\text { (mbsf) }\end{array}$ & NA & NP & A & $\mathrm{P}$ \\
\hline $123-765 C-37 R-3,52-55$ & 696.52 & 4 & 4 & $\mathrm{C}$ & G \\
\hline$-37 R-4,53-57$ & 698.03 & 0 & 0 & Barren & \\
\hline$-37 \mathrm{R}-\mathrm{CC}$ & 698.08 & 2 & 2 & $\mathbf{R}$ & $P$ \\
\hline$-38 R-2,124-128$ & 705.24 & 3 & 3 & $\mathrm{~F}$ & M \\
\hline$-38 R-3,66-70$ & 706.16 & 2 & 2 & $\mathbf{R}$ & \\
\hline$-38 \mathrm{R}-3,79-83$ & 706.29 & 1 & 3 & VR & M \\
\hline$-38 R-4,76-79$ & 707.76 & 2 & 3 & $\mathrm{R}$ & M \\
\hline$-38 R-5,25-29$ & 708.75 & 0 & 0 & Barren & \\
\hline$-38 R-6,41-45$ & 710.41 & 2 & 3 & $\mathbf{R}$ & M \\
\hline$-38 R-6,104-108$ & 711.04 & 2 & 3 & $\mathbf{R}$ & M \\
\hline$-38 \mathrm{R}-\mathrm{CC}$ & 712.13 & 4 & 1 & C & VP \\
\hline$-39 \mathrm{R}-1,29-33$ & 711.99 & 3 & 4 & F & G \\
\hline$-39 R-4,38-40$ & 716.58 & 0 & 0 & Barren & \\
\hline$-39 R-4,72-76$ & 716.92 & 0 & 0 & Barren & \\
\hline$-39 \mathrm{R}-\mathrm{CC}$ & 717.86 & 0 & 0 & Barren & \\
\hline$-40 \mathrm{R}-1,122-124$ & 722.12 & 0 & 0 & Barren & \\
\hline$-40 \mathrm{R}-3,4-7$ & 723.94 & 0 & 0 & Barren & \\
\hline$-40 R-4,46-49$ & 725.86 & 2 & 2 & $\mathbf{R}$ & $\mathbf{P}$ \\
\hline$-40 R-5,18-21$ & 727.08 & 0 & 0 & Barren & \\
\hline$-40 \mathrm{R}-\mathrm{CC}$ & 727.50 & 3 & 1 & F & VP \\
\hline$-41 \mathrm{R}-\mathrm{CC}$ & 731.04 & 0 & 0 & Barren & \\
\hline$-42 R-2,66-68$ & 741.96 & 4 & 2 & C & $\mathrm{P}$ \\
\hline$-42 R-2,138-140$ & 742.68 & 0 & 0 & Barren & \\
\hline$-42 R-3,60-62$ & 743.40 & 5 & 4 & A & G \\
\hline$-42 R-3,140-150$ & 744.20 & 5 & 4 & A & G \\
\hline$-42 R-4,148-150$ & 745.78 & 5 & 4 & A & G \\
\hline$-42 R-5,21-23$ & 746.01 & 0 & 0 & Barren & \\
\hline$-42 \mathrm{R}-\mathrm{CC}$ & 746.42 & 0 & 0 & Barren & \\
\hline$-43 R-1,76-80$ & 749.86 & 5 & 4 & A & G \\
\hline$-43 R-2,14-18$ & 750.74 & 2 & 3 & $\mathbf{R}$ & M \\
\hline$-43 R-3,98-102$ & 753.08 & 5 & 4 & A & G \\
\hline$-43 R-4,81-85$ & 754.41 & 1 & 2 & VR & P \\
\hline$-43 R-5,47-51$ & 755.57 & 4 & 3 & C & M \\
\hline$-43 R-6,79-83$ & 757.39 & 2 & 2 & $\mathbf{R}$ & $\mathrm{P}$ \\
\hline$-43 \mathrm{R}-\mathrm{CC}$ & 757.50 & 2 & 2 & $\mathbf{R}$ & P \\
\hline$-44 \mathrm{R}-1,93-97$ & 759.43 & 0 & 0 & Barren & \\
\hline$-44 R-4,18-19$ & 763.18 & 3 & 1 & F & VP \\
\hline$-44 R-4,34-38$ & 763.34 & 2 & 1 & $\mathbf{R}$ & $\mathbf{P}$ \\
\hline$-44 \mathrm{R}-\mathrm{CC}$ & 764.07 & 0 & 0 & Barren & \\
\hline$-45 R-1,76-80$ & 768.96 & 4 & 3 & C & M \\
\hline$-45 R-1,107-111$ & 769.27 & 5 & 3 & A & M \\
\hline$-45 R-2,26-28$ & 769.96 & 5 & 3 & A & M \\
\hline$-45 R-3,107-110$ & 772.27 & 0 & 0 & Barren & \\
\hline$-45 R-4,52-56$ & 773.22 & 4 & 3 & C & M \\
\hline$-45 \mathrm{R}-\mathrm{CC}$ & 776.91 & 2 & 1 & $\mathbf{R}$ & VP \\
\hline$-46 \mathrm{R}-\mathrm{CC}$ & 780.58 & 0 & 0 & Barren & \\
\hline$-47 \mathrm{R}-2,23-24$ & 789.13 & 2 & 2 & $\mathbf{R}$ & $\mathbf{P}$ \\
\hline$-47 R-2,25-31$ & 789.15 & 2 & 2 & $\mathbf{R}$ & VP \\
\hline$-47 R-3,102-105$ & 791.42 & 1 & 1 & VR & VP \\
\hline$-47 R-5,108-113$ & 794.48 & 2 & 2 & $\mathbf{R}$ & P \\
\hline$-47 \mathrm{R}-\mathrm{CC}$ & 794.52 & 1 & 3 & VR & M \\
\hline$-48 R-2,27-28$ & 798.67 & 4 & 2 & C & P \\
\hline$-48 \mathrm{R}-4,49-52$ & 801.89 & 0 & 0 & Barren & \\
\hline$-48 R-7,4-8$ & 805.94 & 0 & 0 & Barren & \\
\hline$-48 R-7,8-10$ & 805.96 & 0 & 0 & Barren & \\
\hline$-48 \mathrm{R}-\mathrm{CC}$ & 806.54 & 2 & 3 & $\mathbf{R}$ & M \\
\hline$-49 \mathrm{R}-2,39-43$ & 808.19 & 5 & 3 & A & M \\
\hline$-49 \mathrm{R}-2,39-43$ & 808.19 & 5 & 3 & A & M \\
\hline$-49 \mathrm{R}-3,69-75$ & 809.99 & 2 & 4 & $\mathbf{R}$ & G \\
\hline$-49 R-5,108-111$ & 813.38 & 1 & 2 & VR & $\mathbf{P}$ \\
\hline$-49 \mathrm{R}-\mathrm{CC}, 2-4$ & 813.87 & 2 & 2 & $\mathbf{R}$ & P \\
\hline$-50 \mathrm{R}-1,80-83$ & 816.40 & 5 & 3 & A & M \\
\hline$-50 \mathrm{R}-2,40-41$ & 817.50 & 5 & 3 & A & M \\
\hline$-50 R-3,111-115$ & 819.71 & 3 & 4 & F & G \\
\hline$-50 R-4,108-112$ & 821.18 & 5 & 4 & $\mathbf{R}$ & G \\
\hline$-50 R-5,144-148$ & 823.04 & 5 & 4 & A & G \\
\hline$-50 R-6,31-33$ & 823.41 & 5 & 3 & A & M \\
\hline$-50 \mathrm{R}-\mathrm{CC}$ & 823.62 & 2 & 4 & R & G \\
\hline$-51 R-1,48-50$ & 825.48 & 5 & 4 & A & G \\
\hline$-51 \mathrm{R}-2,20-22$ & 826.70 & 2 & 4 & $\mathrm{R}$ & G \\
\hline$-51 R-2,30-32$ & 826.80 & 5 & 4 & A & G \\
\hline$-51 R-3,6-9$ & 828.06 & 5 & 3 & A & M \\
\hline$-51 \mathrm{R}-3,88-90$ & 828.88 & 5 & 4 & A & G \\
\hline$-51 R-4,120-122$ & 830.70 & 5 & 3 & A & M \\
\hline$-51 R-5,130-133$ & 832.30 & 5 & 3 & A & M \\
\hline$-52 \mathrm{R}-1,86-89$ & 835.36 & 5 & 3 & A & M \\
\hline
\end{tabular}


Table 1 (continued).

\begin{tabular}{|c|c|c|c|c|c|}
\hline $\begin{array}{l}\text { Core, section } \\
\text { interval }(\mathrm{cm})\end{array}$ & $\begin{array}{l}\text { Depth } \\
\text { (mbsf) }\end{array}$ & NA & NP & A & $\mathrm{P}$ \\
\hline $123-765 C-52 R-2,68-71$ & 836.68 & 5 & 3 & A & M \\
\hline$-52 \mathrm{R}-2,118-122$ & 837.18 & 5 & 3 & A & M \\
\hline$-52 \mathrm{R}-3,57-61$ & 838.07 & 5 & 4 & A & G \\
\hline$-53 \mathrm{R}-1,0-1$ & 844.10 & 3 & 3 & F & $\mathrm{M}$ \\
\hline$-53 R-1,93-97$ & 845.03 & 5 & 4 & A & G \\
\hline$-53 R-2,102-105$ & 846.62 & 5 & 4 & A & G \\
\hline$-53 R-4,69-72$ & 849.29 & 4 & 2 & $\mathrm{C}$ & $\mathrm{P}$ \\
\hline$-53 R-5,67-71$ & 850.77 & 5 & 4 & A & G \\
\hline$-53 R-6,18-22$ & 851.78 & 4 & 2 & C & $\mathrm{P}$ \\
\hline$-53 R-7,55-59$ & 853.65 & 4 & 2 & C & $\mathrm{P}$ \\
\hline$-53 \mathrm{R}-\mathrm{CC}$ & 853.94 & 3 & 2 & C & M \\
\hline$-54 \mathrm{R}-1,127-129$ & 854.77 & 4 & 3 & C & M \\
\hline$-54 \mathrm{R}-1,130-132$ & 854.80 & 3 & 3 & F & $\mathrm{M}$ \\
\hline$-54 \mathrm{R}-2,128-130$ & 856.28 & 5 & 3 & A & M \\
\hline$-54 R-3,41-43$ & 856.91 & 5 & 4 & A & G \\
\hline$-54 \mathrm{R}-4,0-1$ & 858.00 & 3 & 3 & F & M \\
\hline$-54 \mathrm{R}-4,15-19$ & 858.17 & 4 & 3 & C & $\mathbf{M}$ \\
\hline$-54 R-4,21-24$ & 858.21 & 5 & 4 & A & G \\
\hline$-54 \mathrm{R}-\mathrm{CC}$ & 859.41 & 5 & 4 & A & G \\
\hline$-54 \mathrm{R}-3,140-150$ & 857.90 & 3 & 3 & $\mathrm{~F}$ & $\mathbf{M}$ \\
\hline$-55 \mathrm{R}-1,47-51$ & 863.47 & 1 & 1 & VR & VP \\
\hline$-55 R-2,123-127$ & 865.73 & 3 & 3 & F & M \\
\hline$-55 R-4,83-87$ & 868.33 & 1 & 1 & VR & VP \\
\hline$-55 \mathrm{R}-\mathrm{CC}$ & 868.66 & 0 & 0 & Barren & \\
\hline$-56 R-2,7-8$ & 874.07 & 3 & 3 & C & M \\
\hline$-56 \mathrm{R}-2,18-20$ & 874.18 & 5 & 3 & A & $\mathrm{M}$ \\
\hline$-56 R-4,24-27$ & 877.24 & 1 & 1 & VR & VP \\
\hline$-56 \mathrm{R}-\mathrm{CC}$ & 878.50 & 2 & 2 & $\mathbf{R}$ & $\mathbf{P}$ \\
\hline$-57 R-1,67-70$ & 882.37 & 5 & 4 & A & G \\
\hline$-57 R-2,115-120$ & 884.38 & 4 & 2 & $\mathrm{C}$ & $\mathrm{P}$ \\
\hline$-57 \mathrm{R}-3,4-7$ & 884.74 & 4 & 3 & C & M \\
\hline$-57 R-3,140-150$ & 886.10 & 1 & 1 & VR & VP \\
\hline$-57 R-4,45-47$ & 886.65 & 5 & 3 & A & M \\
\hline$-57 \mathrm{R}-4,51-53$ & 886.71 & 5 & 3 & A & M \\
\hline$-57 R-5,114-117$ & 888.84 & 3 & 3 & $\mathrm{~F}$ & M \\
\hline$-57 R-6,112-114$ & 890.32 & 3 & 3 & $\mathrm{~F}$ & M \\
\hline$-57 \mathrm{R}-\mathrm{CC}$ & 890.75 & 2 & 3 & $\mathrm{R}$ & M \\
\hline$-58 \mathrm{R}-2,65-67$ & 893.35 & 5 & 3 & A & M \\
\hline$-58 \mathrm{R}-3,31-34$ & 894.51 & 5 & 3 & A & $\mathrm{M}$ \\
\hline$-58 \mathrm{R}-3,84-88$ & 895.04 & 5 & 4 & A & G \\
\hline$-58 \mathrm{R}-3,89-93$ & 895.09 & 5 & 4 & A & G \\
\hline$-58 \mathrm{R}-4,0-1$ & 895.70 & 2 & 4 & $\mathrm{R}$ & G \\
\hline$-58 \mathrm{R}-4,0-4$ & 895.70 & 5 & 3 & A & $\mathrm{M}$ \\
\hline$-58 \mathrm{R}-4,88-92$ & 896.52 & 2 & 4 & $\mathrm{R}$ & G \\
\hline$-58 \mathrm{R}-5,53-55$ & 897.73 & 2 & 4 & $\mathrm{R}$ & G \\
\hline$-58 \mathrm{R}-5,89-93$ & 898.09 & 4 & 3 & C & $\mathrm{M}$ \\
\hline$-58 \mathrm{R}-5,143-147$ & 898.63 & 5 & 4 & A & G \\
\hline$-58 \mathrm{R}-\mathrm{CC}$ & 898.68 & 3 & 3 & $\mathrm{~F}$ & $\mathrm{M}$ \\
\hline$-59 \mathrm{R}-1,32-35$ & 898.22 & 5 & 4 & A & G \\
\hline$-59 \mathrm{R}-1,66-68$ & 898.56 & 3 & 4 & C & G \\
\hline$-59 \mathrm{R}-1,123-126$ & 899.13 & 5 & 4 & A & G \\
\hline$-59 \mathrm{R}-1,138-140$ & 899.28 & 4 & 4 & C & G \\
\hline$-59 R-2,96-98$ & 900.36 & 5 & 4 & A & G \\
\hline$-59 \mathrm{R}-2,121-125$ & 900.61 & 3 & 3 & $\mathrm{~F}$ & M \\
\hline$-59 \mathrm{R}-\mathrm{CC}$ & 906.54 & 1 & 2 & VR & $\mathbf{P}$ \\
\hline$-60 \mathrm{R}-1,36-40$ & 907.86 & 1 & 2 & $\mathrm{P}$ & \\
\hline$-60 \mathrm{R}-1,128-130$ & 908.78 & 1 & 1 & VR & VP \\
\hline$-60 \mathrm{R}-2,34-38$ & 909.34 & 2 & 2 & $\mathbf{R}$ & $\mathrm{P}$ \\
\hline$-60 R-2,112-115$ & 910.12 & 2 & 2 & $\mathbf{R}$ & P \\
\hline$-60 R-3,65-68$ & 911.15 & 2 & 2 & R & $\mathbf{P}$ \\
\hline$-60 \mathrm{R}-4,55-57$ & 912.55 & 0 & 0 & Barren & \\
\hline$-60 R-4,126-128$ & 913.26 & 2 & 2 & $\mathbf{R}$ & P \\
\hline$-60 \mathrm{R}-4,148-150$ & 913.48 & 1 & 1 & $\mathrm{R}$ & VP \\
\hline$-60 R-5,40-43$ & 913.90 & 1 & 1 & VR & VP \\
\hline$-60 \mathrm{R}-5,58-60$ & 914.08 & 0 & 0 & Barren & \\
\hline$-60 \mathrm{R}-\mathrm{CC}$ & 914.89 & 1 & 1 & R & VP \\
\hline$-61 R-1,75-79$ & 917.65 & 0 & 0 & Barren & \\
\hline$-61 R-1,91-95$ & 917.81 & 1 & 1 & VR & VP \\
\hline$-61 R-1,107-110$ & 917.97 & 0 & 0 & Barren & \\
\hline$-61 R-2,50-53$ & 918.90 & 0 & 0 & Barren & \\
\hline$-61 R-2,96-100$ & 919.36 & 1 & 1 & $\mathrm{R}$ & M \\
\hline$-61 R-3,20-22$ & 920.10 & 1 & 3 & VR & M \\
\hline$-61 R-4,73-75$ & 922.13 & 0 & 0 & Barren & \\
\hline$-61 R-4,87-89$ & 922.27 & 1 & 1 & VR & VP \\
\hline$-61 R-4,91-93$ & 922.31 & 0 & 0 & Barren & \\
\hline$-61 R-4,94-95$ & 922.33 & 1 & 1 & VR & VP \\
\hline$-61 R-5,52-55$ & 923.42 & 1 & 2 & $\mathbf{R}$ & $\mathrm{P}$ \\
\hline
\end{tabular}

Table 1 (continued).

\begin{tabular}{ccccll}
\hline $\begin{array}{c}\text { Core, section } \\
\text { interval }(\mathrm{cm})\end{array}$ & $\begin{array}{c}\text { Depth } \\
\text { (mbsf) }\end{array}$ & NA & NP & \multicolumn{1}{c}{ A } & P \\
\hline 123-765C-61R-CC, & 924.40 & 0 & 0 & Barren & \\
$-62 \mathrm{R}-1,52-56$ & 926.92 & 1 & 3 & VR & M \\
$-62 \mathrm{R}-1,53-56$ & 926.93 & 1 & 3 & $\mathrm{R}$ & $\mathrm{M}$ \\
$-62 \mathrm{R}-2,36-38$ & 928.26 & 0 & 0 & Barren & \\
$-62 \mathrm{R}-3,42-44$ & 929.82 & 0 & 0 & Barren & \\
\hline
\end{tabular}

Note: Numerical abundance and preservation values range from 0 to 5 as defined in the chapter scope and methods. $0=$ barren, $1=$ very rare/very poor, 2 = rare/poor, 3 = few/moderate, $4=$ common/good, $5=$ abundant/very good.

homogenized, then strewn with a spatula onto fresh carbon paint. After drying, excess residue was knocked off, leaving one layer of attached radiolarians. To avoid the notorious charge-ups, a thick gold sputter coating was applied. For each stub, we produced four SEM photomicrographs of the four different quadrants of the stub, at 40 or 60 times magnification, and enlarged them on 18$\times 24-\mathrm{cm}$ paper, resulting in a paper magnification of 88 or 133 times. All particles were visually counted to obtain the $100 \%$ value for each photo. Then, each taxon group was counted separately and marked off with a specific color pen. If any doubts about the assignment to one of the taxon groups existed, the specimen was left unmarked. Unmarked specimens were counted as nondeterminable radiolarians. The advantage of this procedure is that the counts are fixed on paper and can be verified and revised.

However, when comparing strewn residue in a picking tray with the SEM preparations, we realized that large forms are often less abundant on the stubs, because they are less likely to adhere well to the glue. Most of the data included here are based both on counting of SEM micrographs and on visual examination of a representative split of residue under the binocular microscope using incident light.

Abundances in Table 2 and Figure 3 are defined as follows:

6: Dominant; represents more than $20 \%$ of the total of radiolarians determinable in a residue.

5: Abundant; represents $10 \%$ to $20 \%$ of the total of radiolarians determinable in a residue.

4: Common; represents $5 \%$ to $10 \%$ of the total of radiolarians determinable in a residue.

3: Few; represents $1 \%$ to $5 \%$ of the total of radiolarians determinable in a residue.

2: Rare; represents less than $1 \%$ of the total of radiolarians determinable in a residue.

1: Trace; represents one or, at best, several specimens of several thousand specimens examined.

The majority of species in well-preserved samples fall in category 2 (less than $1 \%$ ). However, it was difficult to find all species of this category in the SEM micrographs, because each photo showed only 100 to 300 specimens and, therefore, only the more abundant taxa were likely to be observed. Several thousand specimens were examined in one or more picking trays, and a complete list of species was established with abundances estimated.

\section{CRETACEOUS RADIOLARIAN BIOSTRATIGRAPHY AT EACH SITE}

In an effort to establish ages based on recorded radiolarian assemblages, Tethyan forms used in previously published zonations (Baumgartner, 1984b; Schaaf, 1985; Sanfilippo and Riedel, $1985)$ were considered. These forms are very rare in the late 
Table 2. Occurrence and abundance of radiolarian taxa studied at Hole 765C, Cores 123-765C-62R through 42R.

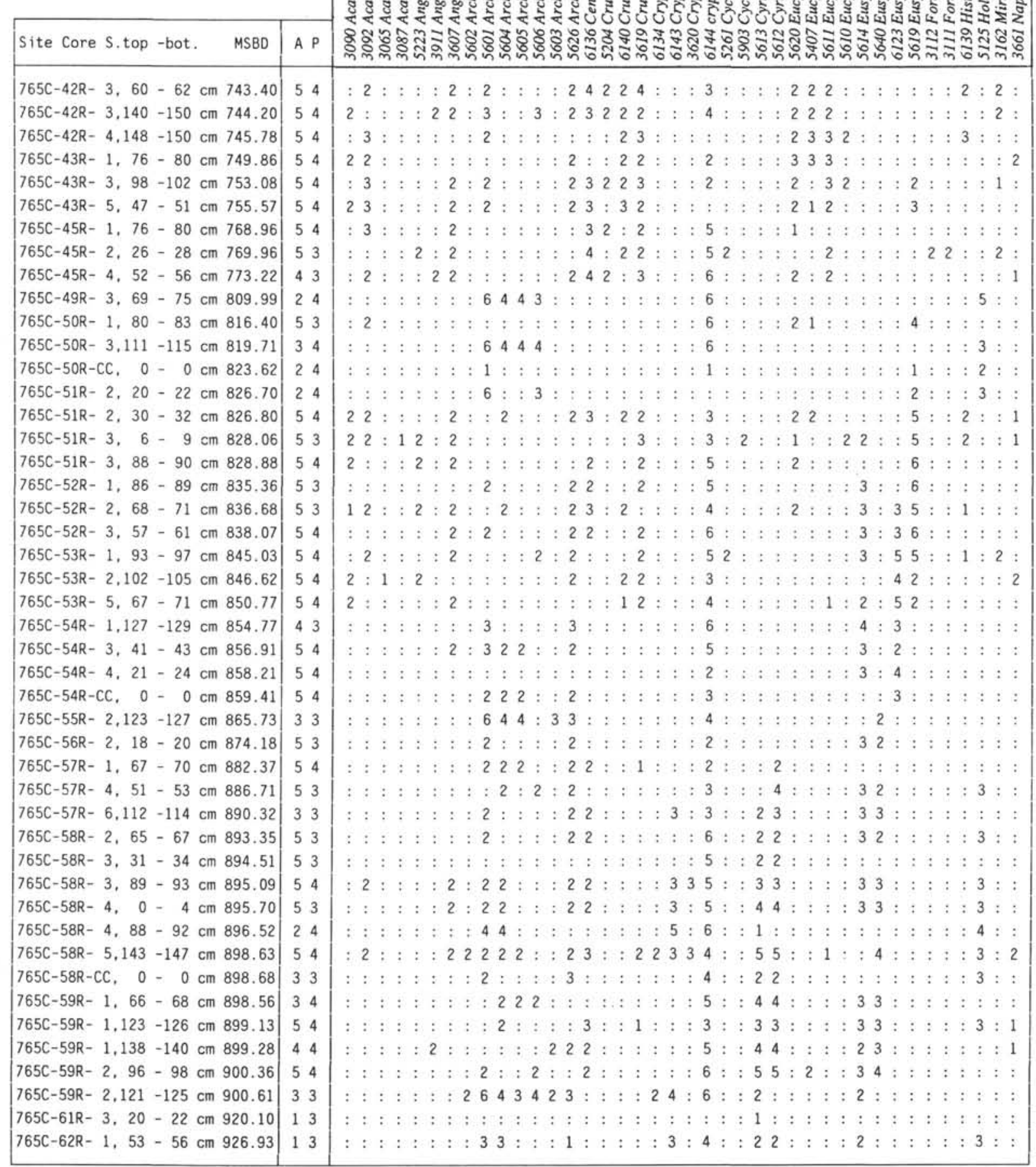


Table 2 (continued).

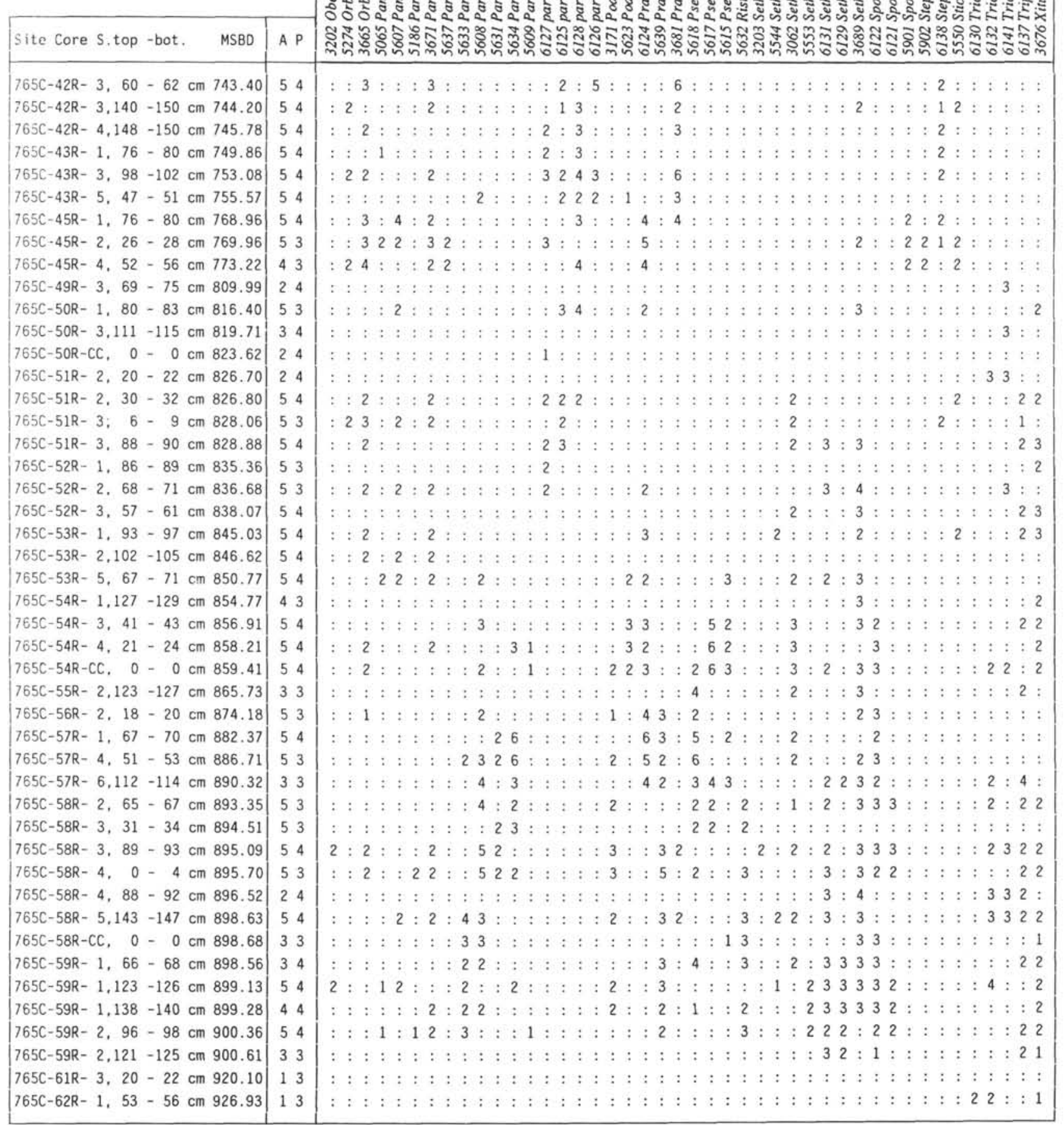


Table 3. Bulk abundance and preservation of radiolarians at Site 766.

\begin{tabular}{|c|c|c|c|c|c|}
\hline $\begin{array}{l}\text { Core, section, } \\
\text { interval }(\mathrm{cm})\end{array}$ & $\begin{array}{l}\text { Depth } \\
\text { (mbsf) }\end{array}$ & NA & NP & A & $\mathrm{P}$ \\
\hline $123-766 \mathrm{~A}-1 \mathrm{R}-1,1-5$ & 0.01 & 3 & 5 & C & VG \\
\hline$-1 R-1,104-109$ & 1.04 & 3 & 5 & C & VG \\
\hline$-1 R-3,25-29$ & 3.25 & 3 & 5 & $\mathrm{C}$ & VG \\
\hline$-1 R-5,1-103$ & 7 & 3 & 5 & C & VG \\
\hline$-1 \mathrm{R}-\mathrm{CC}, 18-20$ & 7.66 & 3 & 5 & C & VG \\
\hline$-2 \mathrm{R}-1,4-7$ & 7.74 & 3 & 5 & VR & G \\
\hline$-2 \mathrm{R}-5,83-84$ & 14.53 & 0 & 0 & Barren & \\
\hline$-2 \mathrm{R}-6,16-2$ & 15.36 & 0 & 0 & Barren & \\
\hline$-2 \mathrm{R}-\mathrm{CC}, 17-19$ & 17.30 & 1 & 4 & VR & G \\
\hline$-3 R-1,3-6$ & 17.33 & 0 & 0 & Barren & \\
\hline$-3 R-6,121-125$ & 25.71 & 0 & 0 & Barren & \\
\hline$-3 R-C C, 22-24$ & 26.54 & 0 & 0 & Barren & \\
\hline$-4 \mathrm{R}-\mathrm{CC}, 7-10$ & 30.92 & 2 & 4 & R & G \\
\hline$-5 \mathrm{R}-\mathrm{CC}, 8-11$ & 44.92 & 0 & 0 & Barren & \\
\hline$-6 R-C C, 7-10$ & 55.59 & 0 & 0 & Barren & \\
\hline$-7 \mathrm{R}-\mathrm{CC}, 10-14$ & 65.51 & 0 & 0 & Barren & \\
\hline$-9 \mathrm{R}-\mathrm{CC}, 23-28$ & 82.98 & 0 & 0 & Barren & \\
\hline$-10 \mathrm{R}-\mathrm{CC}, 10-16$ & 89.53 & 0 & 0 & Barren & \\
\hline$-11 \mathrm{R}-\mathrm{CC}, 5-10$ & 104.09 & 1 & 1 & VR & VP \\
\hline$-12 R-C C, 12-18$ & 105.99 & 0 & 0 & Barren & \\
\hline$-13 \mathrm{R}-\mathrm{CC}, 7-13$ & 118.38 & 0 & 0 & Barren & \\
\hline$-14 \mathrm{R}-\mathrm{CC}, 7-14$ & 130.92 & 0 & 0 & Barren & \\
\hline$-15 \mathrm{R}-\mathrm{CC}, 0-7$ & 141.29 & 1 & 2 & VR & $\mathrm{P}$ \\
\hline$-16 \mathrm{R}-1,80-84$ & 143.70 & 0 & 0 & Barren & \\
\hline$-16 R-2,83-87$ & 145.23 & 0 & 0 & Barren & \\
\hline$-16 \mathrm{R}-4,32-36$ & 147.72 & 0 & 0 & Barren & \\
\hline$-16 \mathrm{R}-6,34-40$ & 150.76 & 0 & 0 & Barren & \\
\hline$-16 R-C C, 0-6$ & 152.09 & 1 & 2 & VR & $\mathbf{P}$ \\
\hline$-17 \mathrm{R}-4,74$ & 157.74 & 0 & 0 & Barren & \\
\hline$-17 \mathrm{R}-7,30-33$ & 161.80 & 1 & 2 & VR & P \\
\hline$-17 \mathrm{R}-\mathrm{CC}, 6-14$ & 162.02 & 1 & 2 & VR & $\mathrm{P}$ \\
\hline$-18 \mathrm{R}-1,104-106$ & 163.14 & 1 & 1 & VR & VP \\
\hline$-18 \mathrm{R}-2,1-103$ & 164.60 & 1 & 2 & VR & $\mathrm{P}$ \\
\hline$-18 R-3,68-70$ & 165.78 & 2 & 2 & R & $\mathrm{P}$ \\
\hline$-18 \mathrm{R}-4,139-43$ & 167.99 & 1 & 1 & VR & VP \\
\hline$-18 R-5,112-116$ & 169.22 & 1 & 2 & VR & $\mathrm{P}$ \\
\hline$-18 \mathrm{R}-6,26-30$ & 169.86 & 3 & 2 & F & P \\
\hline$-18 \mathrm{R}-\mathrm{CC}$ & 170.26 & 2 & 3 & $\mathrm{R}$ & M \\
\hline$-19 \mathrm{R}-1,71-74$ & 172.41 & 1 & 1 & VR & VP \\
\hline$-19 R-2,13-15$ & 173.33 & 2 & 2 & $\mathrm{R}$ & $\mathrm{P}$ \\
\hline$-19 \mathrm{R}-2,25-29$ & 173.45 & 2 & 2 & $\mathbf{R}$ & $\mathbf{P}$ \\
\hline$-19 \mathrm{R}-2,79-83$ & 173.99 & 0 & 0 & Barren & \\
\hline$-19 \mathrm{R}-4,20-24$ & 176.40 & 3 & 2 & $\mathrm{~F}$ & $\mathrm{P}$ \\
\hline$-19 R-4,98-102$ & 177.18 & 0 & 0 & Barren & \\
\hline$-19 R-5,44-47$ & 178.14 & 1 & 2 & VR & $\mathrm{P}$ \\
\hline -19R-CC, & 178.62 & 1 & 1 & VR & VP \\
\hline$-20 \mathrm{R}-1,13-16$ & 181.53 & 1 & 4 & VR & G \\
\hline$-20 \mathrm{R}-2,81-85$ & 183.71 & 2 & 3 & $\mathbf{R}$ & M \\
\hline$-20 \mathrm{R}-3,137-141$ & 185.77 & 0 & 0 & Barren & \\
\hline$-20 \mathrm{R}-\mathrm{CC}$ & 186.53 & 2 & 3 & $\mathrm{R}$ & $\mathrm{M}$ \\
\hline$-21 R-1,59-63$ & 191.59 & 2 & 2 & $\mathbf{R}$ & $\mathrm{P}$ \\
\hline$-21 \mathrm{R}-1,139-142$ & 192.39 & 1 & 1 & VR & VP \\
\hline$-21 \mathrm{R}-1,147-149$ & 192.47 & 1 & 2 & VR & $\mathrm{P}$ \\
\hline$-21 R-2,47-51$ & 192.97 & 0 & 0 & Barren & \\
\hline$-21 R-2,86-89$ & 193.36 & 0 & 0 & Barren & \\
\hline$-21 \mathrm{R}-\mathrm{CC}$ & 193.57 & 1 & 3 & VR & $\mathrm{M}$ \\
\hline$-22 \mathrm{R}-1,8-12$ & 2.68 & 0 & 0 & Barren & \\
\hline$-22 \mathrm{R}-1,16-18$ & 2.76 & 1 & 3 & VR & M \\
\hline$-22 \mathrm{R}-\mathrm{CC}$ & 2.96 & 4 & 4 & $\mathrm{C}$ & G \\
\hline$-23 \mathrm{R}-1,0-1$ & 210.30 & 1 & 3 & $\mathrm{~F}$ & M \\
\hline$-23 \mathrm{R}-1,11-14$ & 210.41 & 2 & 2 & R & $\mathrm{P}$ \\
\hline$-23 \mathrm{R}-1,36-38$ & 210.66 & 2 & 2 & $\mathbf{R}$ & $\mathbf{P}$ \\
\hline$-23 \mathrm{R}-\mathrm{CC}$ & 210.82 & 4 & 4 & A & G \\
\hline$-24 R-1,43-45$ & 220.33 & 1 & 2 & VR & $\mathbf{P}$ \\
\hline$-24 \mathrm{R}-1,103-105$ & 220.93 & 1 & 3 & VR & M \\
\hline$-24 \mathrm{R}-\mathrm{CC}, 0-5$ & 221.57 & 4 & 4 & C & G \\
\hline$-24 \mathrm{R}-\mathrm{CC}, 10-13$ & 221.67 & 2 & 3 & $\mathrm{R}$ & M \\
\hline$-25 R-1,1-3$ & 229.61 & 1 & 1 & VR & VP \\
\hline$-25 R-1,3-6$ & 229.63 & 2 & 3 & $\mathbf{R}$ & M \\
\hline$-25 \mathrm{R}-1,83-87$ & 230.43 & 1 & 2 & VR & P \\
\hline$-25 \mathrm{R}-\mathrm{CC}, 12-16$ & 230.61 & 4 & 4 & C & G \\
\hline$-26 \mathrm{R}-1,47-51$ & 239.77 & 4 & 3 & C & M \\
\hline$-26 \mathrm{R}-2,145-148$ & 242.25 & 4 & 4 & C & G \\
\hline$-26 \mathrm{R}-2,150-151$ & 242.30 & 4 & 2 & C & $\mathbf{P}$ \\
\hline$-26 \mathrm{R}-3,47-49$ & 242.77 & 2 & 2 & $\mathbf{R}$ & $\mathbf{P}$ \\
\hline$-26 \mathrm{R}-\mathrm{CC}, 0-4$ & 243.71 & 3 & 2 & $\mathbf{F}$ & $\mathrm{P}$ \\
\hline$-27 \mathrm{R}-1,50-054$ & 249.40 & 2 & 2 & $\mathbf{R}$ & $\mathbf{P}$ \\
\hline$-27 \mathrm{R}-2,121-125$ & 251.61 & 2 & 2 & $\mathbf{R}$ & $\mathbf{P}$ \\
\hline$-27 R-3,6-9$ & 251.96 & 3 & 2 & $\mathrm{~F}$ & $P$ \\
\hline$-27 R-C C, 16-23$ & 252.25 & 1 & 2 & VR & $\mathbf{P}$ \\
\hline
\end{tabular}

Table 3 (continued).

\begin{tabular}{|c|c|c|c|c|c|}
\hline $\begin{array}{l}\text { Core, section, } \\
\text { interval }(\mathrm{cm})\end{array}$ & $\begin{array}{l}\text { Depth } \\
\text { (mbsf) }\end{array}$ & NA & NP & A & $\mathrm{P}$ \\
\hline 123-766A-28R-1, 89-93 & 259.49 & 2 & 2 & $\mathrm{R}$ & $\mathbf{P}$ \\
\hline$-28 R-2,91-95$ & 261.01 & 2 & 2 & $\mathbf{R}$ & $\mathrm{P}$ \\
\hline$-28 R-3,40-44$ & 262 & 2 & 3 & $\mathrm{R}$ & $\mathrm{M}$ \\
\hline$-28 R-6,51-56$ & 266.61 & 2 & 3 & $\mathrm{R}$ & M \\
\hline$-28 \mathrm{R}-\mathrm{CC}, 10-16$ & 267.92 & 3 & 3 & F & M \\
\hline$-28 R-3,97-101$ & 272.27 & 2 & 3 & $\mathrm{R}$ & M \\
\hline$-29 \mathrm{R}-4,0-1$ & 272.80 & 1 & 2 & VR & $\mathrm{P}$ \\
\hline$-29 R-4,13-16$ & 272.93 & 2 & 3 & $\mathrm{R}$ & M \\
\hline$-29 \mathrm{R}-\mathrm{CC}, 10-16$ & 274.83 & 3 & 3 & C & $\mathrm{M}$ \\
\hline$-30 R-3,65-68$ & 281.55 & 1 & 3 & VR & M \\
\hline$-30 R-4,46-48$ & 282.86 & 1 & 2 & VR & $P$ \\
\hline$-30 \mathrm{R}-4,103-105$ & 283.43 & 1 & 3 & VR & M \\
\hline$-30 \mathrm{R}-\mathrm{CC}, 0-6$ & 283.95 & 0 & 0 & Barren & \\
\hline$-31 \mathrm{R}-1,109-111$ & 288.59 & 0 & 0 & Barren & \\
\hline$-31 \mathrm{R}-2,0-4$ & 289 & 0 & 0 & Barren & \\
\hline$-31 \mathrm{R}-\mathrm{CC}, 3-10$ & 291.32 & 0 & 0 & Barren & \\
\hline$-32 \mathrm{R}-1,35-37$ & 297.55 & 0 & 0 & Barren & \\
\hline$-32 \mathrm{R}-\mathrm{CC}, 0-10$ & 304.24 & 1 & 1 & VR & VP \\
\hline -33R-1, 97-99 & 307.77 & 2 & 2 & $\mathrm{R}$ & $P$ \\
\hline$-33 \mathrm{R}-\mathrm{CC}, 2-9$ & 310.70 & 1 & 1 & VR & VP \\
\hline$-36 \mathrm{R}-1,36-41$ & 336.16 & 0 & 0 & Barren & \\
\hline$-40 \mathrm{R}-1,122-126$ & 375.72 & 1 & 2 & VR & $\mathrm{P}$ \\
\hline$-40 \mathrm{R}-5,133-137$ & 381.83 & 2 & 3 & $\mathbf{R}$ & M \\
\hline$-40 R-6,33-37$ & 382.33 & 2 & 3 & $\mathbf{R}$ & M \\
\hline -40R-CC, & 384.05 & 1 & 1 & VR & VP \\
\hline$-41 R-2,3-6$ & 385.73 & 1 & 2 & VR & P \\
\hline$-41 R-4,96-98$ & 389.66 & 1 & 2 & VR & $\mathbf{P}$ \\
\hline$-41 R-C C$, & 392.09 & 1 & 0 & VR & \\
\hline$-42 R-1,143-146$ & 395.23 & 1 & 2 & VR & $\mathbf{P}$ \\
\hline$-42 R-4,98-100$ & 399.28 & 1 & 2 & VR & P \\
\hline$-42 \mathrm{R}-\mathrm{CC}$, & 404.56 & 1 & 1 & VR & VP \\
\hline$-43 R-1,118-122$ & 404.68 & 2 & 2 & $\mathbf{R}$ & P \\
\hline$-43 R-4,142-146$ & 409.42 & 2 & 1 & $\mathbf{R}$ & VP \\
\hline$-43 \mathrm{R}-\mathrm{CC}, 0-4$ & 410.88 & 0 & 0 & Barren & \\
\hline$-44 \mathrm{R}-1,143-147$ & 414.63 & 1 & 2 & VR & $\mathrm{P}$ \\
\hline$-44 R-4,0-1$ & 417.70 & 1 & 1 & VR & VP \\
\hline$-44 R-5,143-147$ & 420.63 & 0 & 0 & Barren & \\
\hline$-44 R-6,90-94$ & 421.60 & 1 & 1 & VR & VP \\
\hline$-44 \mathrm{R}-\mathrm{CC}, 10-15$ & 421.96 & 1 & 2 & VR & P \\
\hline$-45 \mathrm{R}-1,138-142$ & 424.18 & 1 & 1 & VR & VP \\
\hline$-45 R-2,86-90$ & 425.16 & 1 & 1 & VR & VP \\
\hline$-45 R-5,50-55$ & 429.30 & 0 & 0 & Barren & \\
\hline$-45 R-6,40-44$ & 430.70 & 0 & 0 & Barren & \\
\hline$-45 \mathrm{R}-\mathrm{CC}, 0-7$ & 432.32 & 1 & 1 & VR & VP \\
\hline$-46 R-1,111-114$ & 433.65 & 1 & 1 & VR & VP \\
\hline$-46 \mathrm{R}-2,74-78$ & 434.78 & 1 & 1 & VR & VP \\
\hline$-46 \mathrm{R}-3,115-118$ & 436.69 & 1 & 1 & VR & VP \\
\hline$-46 R-5,69-73$ & 439.23 & 1 & 1 & VR & VP \\
\hline$-46 \mathrm{R}-\mathrm{CC}, 0-7$ & 441.61 & 1 & 1 & VR & VP \\
\hline$-47 \mathrm{R}-1,125-130$ & 443.45 & 1 & 1 & VR & VP \\
\hline$-47 R-2,126-131$ & 444.96 & 1 & 1 & VR & VP \\
\hline$-47 \mathrm{R}-3,126-131$ & 446.46 & 1 & 1 & VR & VP \\
\hline$-47 \mathrm{R}-4,128-134$ & 447.98 & 1 & 1 & VR & VP \\
\hline$-47 R-5,127-131$ & 449.47 & 1 & 1 & VR & VP \\
\hline$-47 \mathrm{R}-5,127-133$ & 449.47 & 1 & 1 & VR & VP \\
\hline$-47 \mathrm{R}-6,127-132$ & 450.97 & 2 & 2 & $\mathbf{R}$ & $\mathrm{P}$ \\
\hline$-47 R-6,138-141$ & 451.08 & 2 & 3 & R & M \\
\hline$-47 \mathrm{R}-\mathrm{CC}$ & 451.74 & 2 & 1 & $\mathrm{R}$ & VP \\
\hline$-48 \mathrm{R}-1,135-139$ & 453.15 & 1 & 2 & VR & $\mathrm{P}$ \\
\hline$-48 R-2,107-110$ & 454.37 & 1 & 2 & VR & P \\
\hline$-48 R-4,73-77$ & 457.03 & 1 & 1 & VR & VP \\
\hline$-48 R-5,128-132$ & 459.08 & 1 & 2 & VR & $\mathrm{P}$ \\
\hline$-48 \mathrm{R}-6,0-2$ & 459 & 1 & 1 & VR & VP \\
\hline$-48 R-6,105-109$ & 460.35 & 0 & 0 & Barren & \\
\hline$-48 R-6,117-120$ & 460.47 & 0 & 0 & Barren & \\
\hline$-48 R-6,121-125$ & 460.51 & 1 & 2 & VR & $\mathbf{P}$ \\
\hline -49R-1, 95-97 & 462.45 & 1 & 1 & VR & VP \\
\hline$-49 \mathrm{R}-1,106-110$ & 462.56 & 1 & 1 & VR & VP \\
\hline$-49 \mathrm{R}-1,127-130$ & 462.77 & 1 & 1 & VR & VP \\
\hline$-49 \mathrm{R}-2,86-90$ & 463.86 & 1 & 1 & VR & VP \\
\hline$-49 \mathrm{R}-2,132-136$ & 464.32 & 0 & 0 & Barren & \\
\hline$-49 R-3,6-9$ & 464.56 & 2 & 1 & $\mathbf{R}$ & VP \\
\hline$-49 \mathrm{R}-3,86-88$ & 465.36 & 1 & 1 & VR & VP \\
\hline$-49 \mathrm{R}-3,92-94$ & 465.42 & 2 & 3 & $\mathbf{R}$ & M \\
\hline$-49 R-3,113-116$ & 465.63 & 2 & 2 & $\mathbf{R}$ & $P$ \\
\hline$-49 R-4,23-26$ & 466.23 & 3 & 3 & $\mathrm{R}$ & M \\
\hline$-49 R-4,46-49$ & 466.46 & 1 & 1 & VR & VP \\
\hline
\end{tabular}

Note: Abundance and preservation as defined in text and Table 1. 
Table 4. Some preliminary data about occurrence (and abundance) of radiolarian taxa studied at Site 766, Cores 123-766A-18R through 49R.

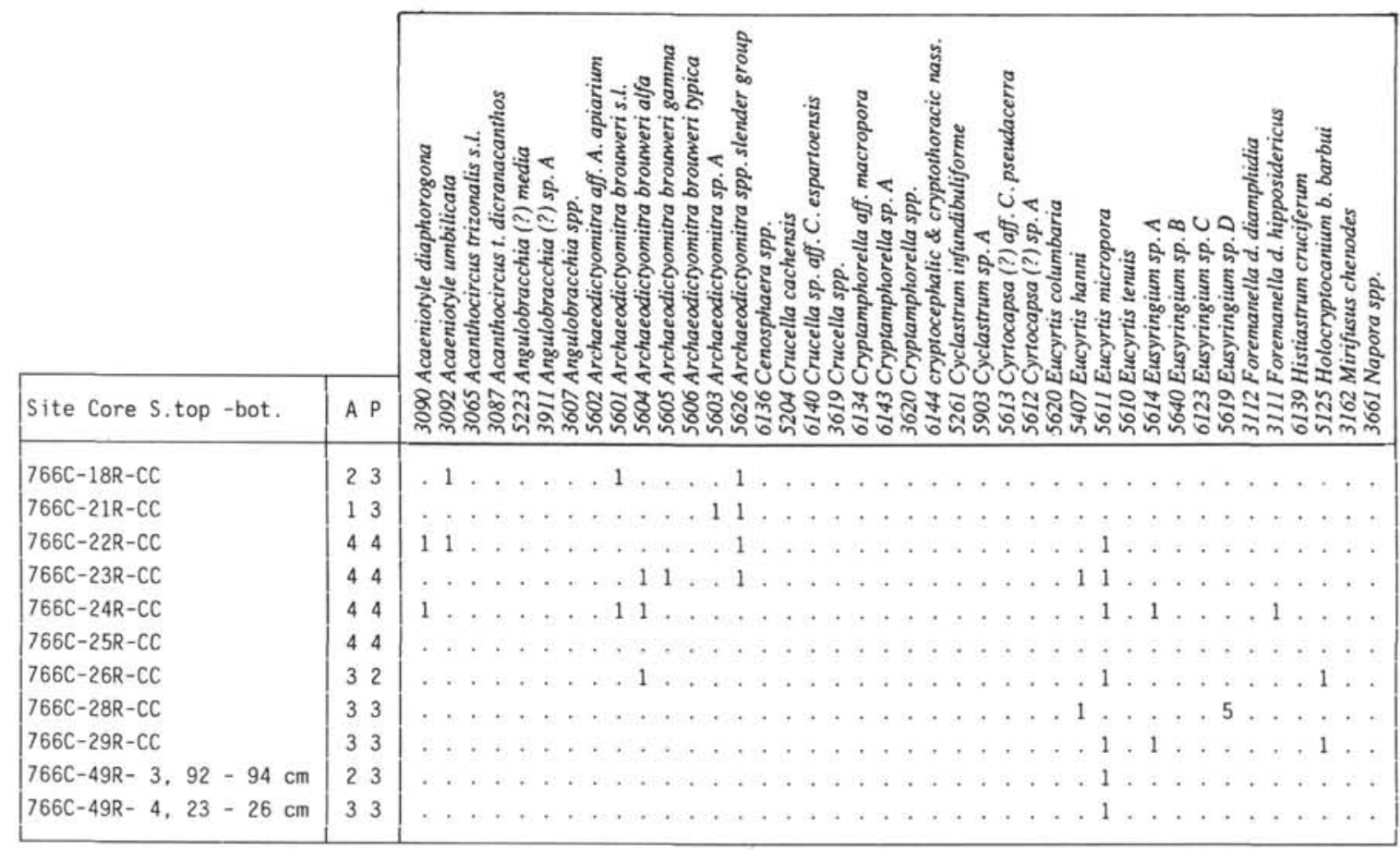

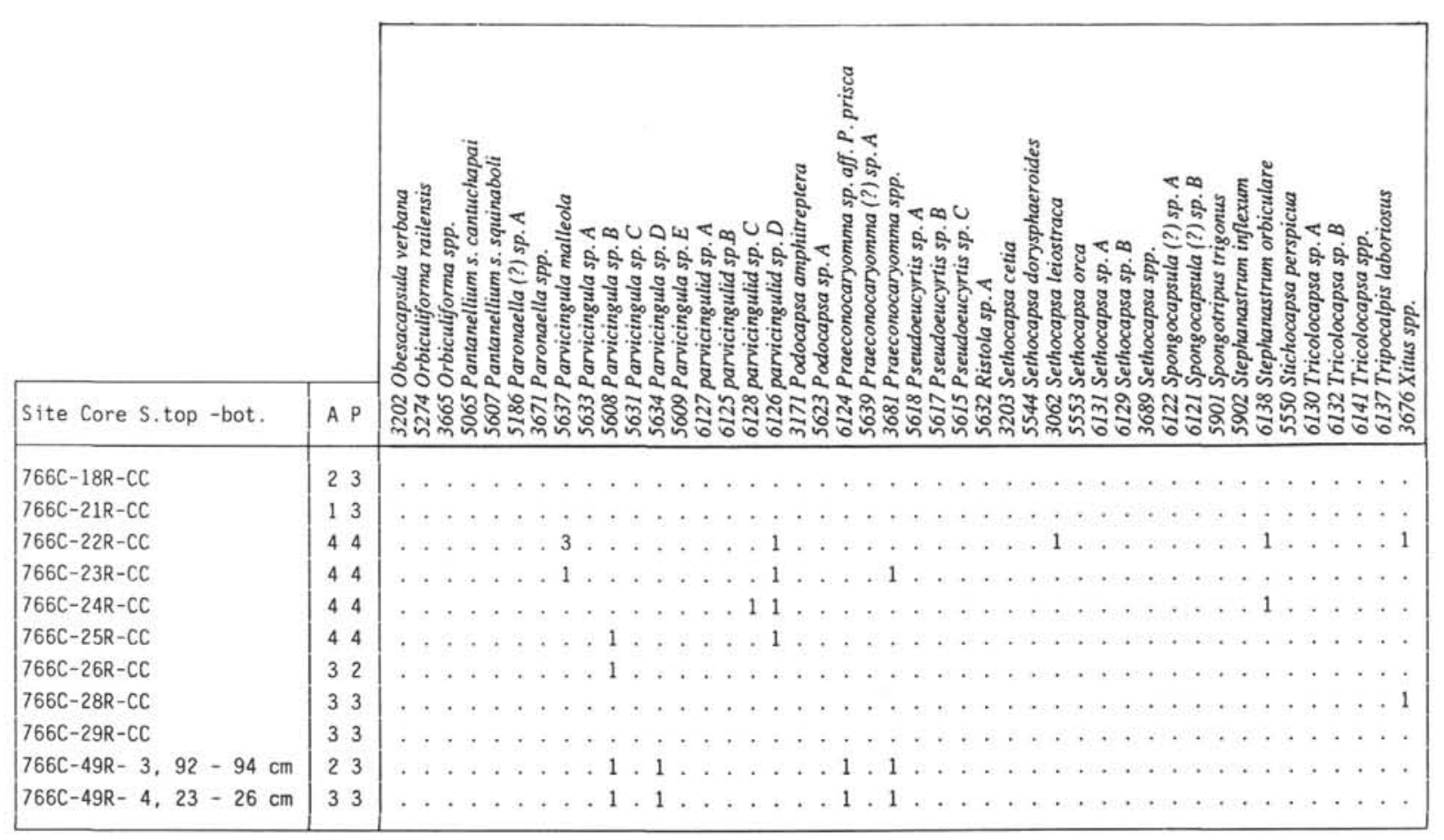

Tithonian-Berriasian to earliest Valanginian interval in the Argo Basin. They are virtually absent from the Valanginian to Hauterivian, but gradually reappear and become more abundant and diverse through the Barremian and lower Aptian. An interpretation of this distribution is presented in this study later, and the observed forms that are unknown from Tethys are also discussed.

\section{Radiolarians at Site 765}

Coring in Hole $765 \mathrm{C}$ began at $350.2 \mathrm{mbsf}$, with scientists using a rotary-core-barrel drilling system, and ended at a depth of 964 mbsf after a penetration of approximately $30 \mathrm{~m}$ of basaltic basement. The hole intersected a middle Miocene to late Tithonian- 
Table 5. Bulk abundance and preservation of radiolarians at DSDP Site 27-261, Cores 9 through 33.

\begin{tabular}{|c|c|c|c|c|c|}
\hline $\begin{array}{l}\text { Core, section, } \\
\text { interval }(\mathrm{cm})\end{array}$ & $\begin{array}{l}\text { Depth } \\
\text { (mbsf) }\end{array}$ & NA & NP & A & $\mathrm{P}$ \\
\hline $261-9-1,141-144$ & 200.91 & 2 & 3 & $\mathbf{R}$ & M \\
\hline $9-2,104-108$ & 202.04 & 2 & 3 & $\mathrm{R}$ & M \\
\hline $9-3,124-128$ & 203.74 & 2 & 3 & $\mathbf{R}$ & M \\
\hline $9-4,51-55$ & 204.51 & 2 & 4 & $\mathrm{R}$ & G \\
\hline $9-4,111-114$ & 205.11 & 4 & 4 & $\mathrm{C}$ & G \\
\hline $12-2,114-120$ & 230.64 & 0 & 0 & Barren & \\
\hline $12-2,136-139$ & 230.86 & 0 & 0 & Barren & \\
\hline $14-1,138-140$ & 248.38 & 2 & 2 & $\mathrm{R}$ & $\mathbf{P}$ \\
\hline $16-1,139-142$ & 267.30 & 4 & 3 & C & M \\
\hline $18-1,130-133$ & 286.30 & 2 & 3 & $\mathrm{R}$ & M \\
\hline $19-1,138-144$ & 305.38 & 0 & 0 & Barren & \\
\hline $19-4,74-77$ & 309.24 & 1 & 3 & VR & M \\
\hline $19-5,109-113$ & 311.09 & 0 & 0 & Barren & \\
\hline $20-1,138-142$ & 314.88 & 1 & 4 & VR & G \\
\hline $21-2,2-4$ & 334.02 & 4 & 4 & $\mathrm{C}$ & G \\
\hline $21-2,145-146$ & 335.45 & 5 & 4 & A & G \\
\hline $21-3,2-6$ & 335.52 & 0 & 0 & Barren & \\
\hline $21-3,59-64$ & 336.09 & 1 & 4 & VR & G \\
\hline $22-1,109-113$ & 343.09 & 1 & 4 & VR & G \\
\hline $22-1,133-138$ & 343.33 & 1 & 3 & VR & M \\
\hline $22-2,103-107$ & 344.53 & 4 & 4 & $\mathrm{C}$ & G \\
\hline $22-3,106-110$ & 346.06 & 1 & 4 & VR & G \\
\hline $22-4,83-87$ & 347.33 & 1 & 4 & VR & G \\
\hline $22-5,71-75$ & 348.71 & 1 & 4 & VR & G \\
\hline $23-1,35-37$ & 361.35 & 1 & 2 & VR & $\mathrm{P}$ \\
\hline $23-2,34-37$ & 362.84 & 1 & 2 & VR & P \\
\hline $23-3,53-57$ & 364.53 & 0 & 0 & Barren & \\
\hline $24-1,134-138$ & 381.34 & 1 & 2 & VR & P \\
\hline $24-2,122-126$ & 382.72 & 0 & 0 & Barren & \\
\hline $25-2,25-28$ & 400.75 & 1 & 3 & VR & M \\
\hline $25-3,138-141$ & 403.38 & 1 & 2 & VR & P \\
\hline $26-1,93-95$ & 418.93 & 1 & 2 & VR & P \\
\hline $26-2,74-76$ & 420.24 & 1 & 2 & VR & P \\
\hline $27-1,68-69$ & 437.68 & 1 & 3 & VR & M \\
\hline $27-1,74-76$ & 437.74 & 1 & 3 & VR & M \\
\hline $27-2,66-70$ & 439.16 & 3 & 3 & $\mathrm{~F}$ & M \\
\hline $27-2,70-73$ & 439.20 & 4 & 4 & C & G \\
\hline $28-1,79-82$ & 447.29 & 1 & 4 & VR & G \\
\hline $28-1,130-133$ & 447.80 & 1 & 3 & VR & M \\
\hline $28-3,50-52$ & 450.00 & 2 & 3 & $\mathrm{R}$ & M \\
\hline $28-4,16-20$ & 451.16 & 2 & 3 & $\mathbf{R}$ & M \\
\hline $29-1,130-135$ & 466.80 & 2 & 4 & $\mathrm{R}$ & G \\
\hline $29-2,95-96$ & 467.95 & 1 & 3 & VR & M \\
\hline $29-2,125-127$ & 468.25 & 2 & 4 & R & G \\
\hline $29-2,143-146$ & 468.43 & 2 & 4 & $\mathrm{R}$ & G \\
\hline $29-3,128-131$ & 469.78 & 2 & 4 & $\mathbf{R}$ & G \\
\hline $29-3,138-141$ & 469.88 & 2 & 4 & $\mathbf{R}$ & G \\
\hline $30-3,125-128$ & 488.75 & 0 & 0 & Barren & \\
\hline $30-3,138-141$ & 488.88 & 0 & 0 & Barren & \\
\hline $31-2,120-122$ & 506.20 & 0 & 0 & Barren & \\
\hline $31-2,124-127$ & 506.24 & 0 & 0 & Barren & \\
\hline $31-3,39-43$ & 506.89 & 0 & 0 & Barren & \\
\hline $31-4,0-4$ & 508.00 & 0 & 0 & Barren & \\
\hline $31-5,75-78$ & 510.25 & 0 & 0 & Barren & \\
\hline $32-2,93-95$ & 524.93 & 0 & 0 & Barren & \\
\hline $32-2,111-113$ & 525.11 & 0 & 0 & Barren & \\
\hline $32-3,143-145$ & 526.93 & 0 & 0 & Barren & \\
\hline $33-1,4-6$ & 532.04 & 0 & 0 & Barren & \\
\hline
\end{tabular}

Note: Abundance and perservation as defined in text and Table 1.

Berriasian sequence. Following a thick Neogene sequence, the Paleogene and Upper Cretaceous are relatively condensed and contain several significant hiatuses. However, the lower Albian to late Tithonian-Berriasian sequence is thicker and more complete.

Well-preserved radiolarians provide biostratigraphic detail in the Quaternary and Lower Cretaceous. General abundances and preservation of all studied radiolarian samples at this site are given in Table 1. Abundances of nearly all observed radiolarian taxa are given for a selection of well-preserved Lower Cretaceous samples in Table 2.

All core-catcher Samples 123-765C-1R-CC through -20R-CC are barren, except for Sample 123-765C-11R-CC, which contains rare and poorly preserved indeterminate Paleogene radiolarians.

Cores 123-765B-21R through -27R contain scattered rare and moderately preserved radiolarians that are clearly reworked. Sample 123-765C-21R-CC contains Foremanina sp., known from the Upper Cretaceous (Campanian). Sample 123-765C-22R-CC contains Sethocapsa leiostraca, known from the Lower Cretaceous. Sample 123-765C-24R-1, 0-1 cm, and Sample 123-765C-27R-1, $87-88 \mathrm{~cm}$, contain reworked assemblages typical of the upper Hauterivian to Valanginian that were recovered farther downhole (Cores 123-765C-54R through -57R). These observations suggest that a relatively thin Cretaceous sequence was being eroded during the Latest Cretaceous and earliest Paleogene, probably by downcutting turbidites.

Cores $123-765 \mathrm{C}-30 \mathrm{R}$ through $-41 \mathrm{R}$ contain mostly nondeterminable radiolarians that have been generally replaced by carbonates (rhodochrosite) or zeolites. In Sample 123-765C-33R-CC, the mid-Cretaceous Halesium sexangulum was recorded. Radiolarian ghosts made of rhodochrosite are common to abundant in Cores 123-765B-30R through $-34 \mathrm{R}$, whereas the residues of Cores $123-765 B-40 R$ and $123-765 B-42 R$ through $-44 R$ contain abundant rhodochrosite spherules that must have formed partly in situ as concretions. However, some occur in laminated, sizesorted layers, suggesting winnowing and/or redeposition.

The interval between Sample 123-765C-42R-3, 60-62 cm, and Sample 123-765C-45R-5, 52-55 cm (Table 2) yielded abundant, moderately preserved and diverse assemblages that are assignable to the lower Sethocapsa euganea Zone (Schaaf, 1985), indicating an early Aptian age. Species include Stichocapsa perspicua $(=S$. euganea), Eucyrtis columbaria, Parvicingula malleola, Mirifusus chenodes, Crucella cachensis, Eucyrtis tenuis, Foremanella hipposidericus, and Stephanastrum inflexum.

Cores $123-765 B-49 R$ through $-62 R$ contain a continuous section with moderately to well-preserved, abundant radiolarians that have been tentatively interpreted as late Barremian to late Tithonian-Berriasian. Radiolarian dating is hampered by the paucity of "cosmopolitan" marker species having ranges known from other oceans (Schaaf, 1985; Sanfilippo and Riedel, 1985). Between Samples 765C-53R-5, 67--71 cm, and 765C-58R-3, 89-93 cm, Tethyan species are almost totally absent (Fig. 3). First occurrences (FOs) at the top or just above that interval are probably the result of paleoceanographic changes, rather than a representation of true FOs. Some of these samples are discussed below in more detail.

Sample $123-765 \mathrm{C}-49 \mathrm{R}-2,39-43 \mathrm{~cm}$, is characterized by the lowest ocurrence of ?Parvicingula malleola, together with the occurrence of Pseudodictyomitra lilyae, Eucyrtis tenuis, Eucyrtis columbaria, and Sethocapsa leiostraca. This assemblage is characteristic of the upper Barremian (combining several sources of known ranges).

The FOs of Eucyrtis tenuis and E. columbaria were found in Sample 123-765C-52R-2, 68-71 cm, indicating a late Hauterivian to early Barremian age.

Sample 123-765C-54R-CC shows the last occurrence of Podocapsa amphitreptera. The last appearance of this species elsewhere is known to be in the upper Valanginian. Considering the biostratigraphic data of nannofossils and palynomorphs, however, this datum occurs here in the upper Barremian-lower Hauterivian. Reworking can be excluded, as this species is common in all samples down to the bottom of the sedimentary section. In addition, Podocapsa sp. A., a descendant species of $P$. amphitreptera, has its FO in Sample 123-765C-54-CC, suggesting that $P$. amphi- 


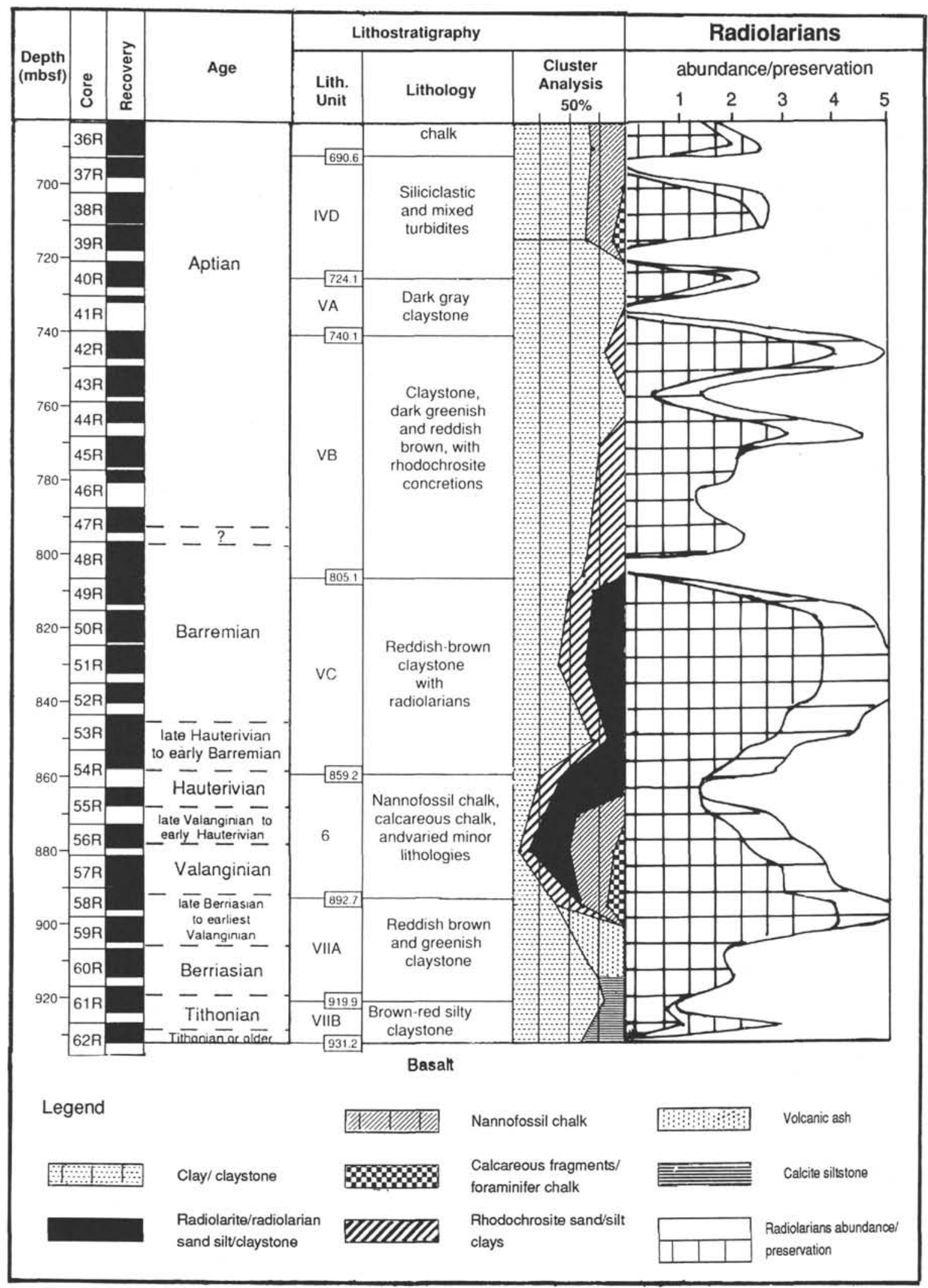

Figure 2. Radiolarian abundance and preservation vs. depth and lithology in Hole 765C. Numerical abundance (horizontal lines) and preservation (vertical lines) are extracted from Table 1, the values range from 0 to 5 , as defined in the chapter scope and methods. $0=$ barren, $1=$ very rare/very poor, $2=$ rare/poor, $3=\mathrm{few} / \mathrm{moderate}, 4=$ common/good, $5=$ abundant $/ \mathrm{very}$ good. Cluster analysis and smoothed radiolarian abundance/preservation curves show good agreement. Abundant and well-preserved radiolarians in Cores $123-765 \mathrm{C}-48 \mathrm{R}$ to $59 \mathrm{R}$ occur principally in radiolarite layers, whereas above Core 123-765C-48R, radiolarians are disseminated in claystones or are associated with rhodochrosite sand layers. See further discussion in the text. 


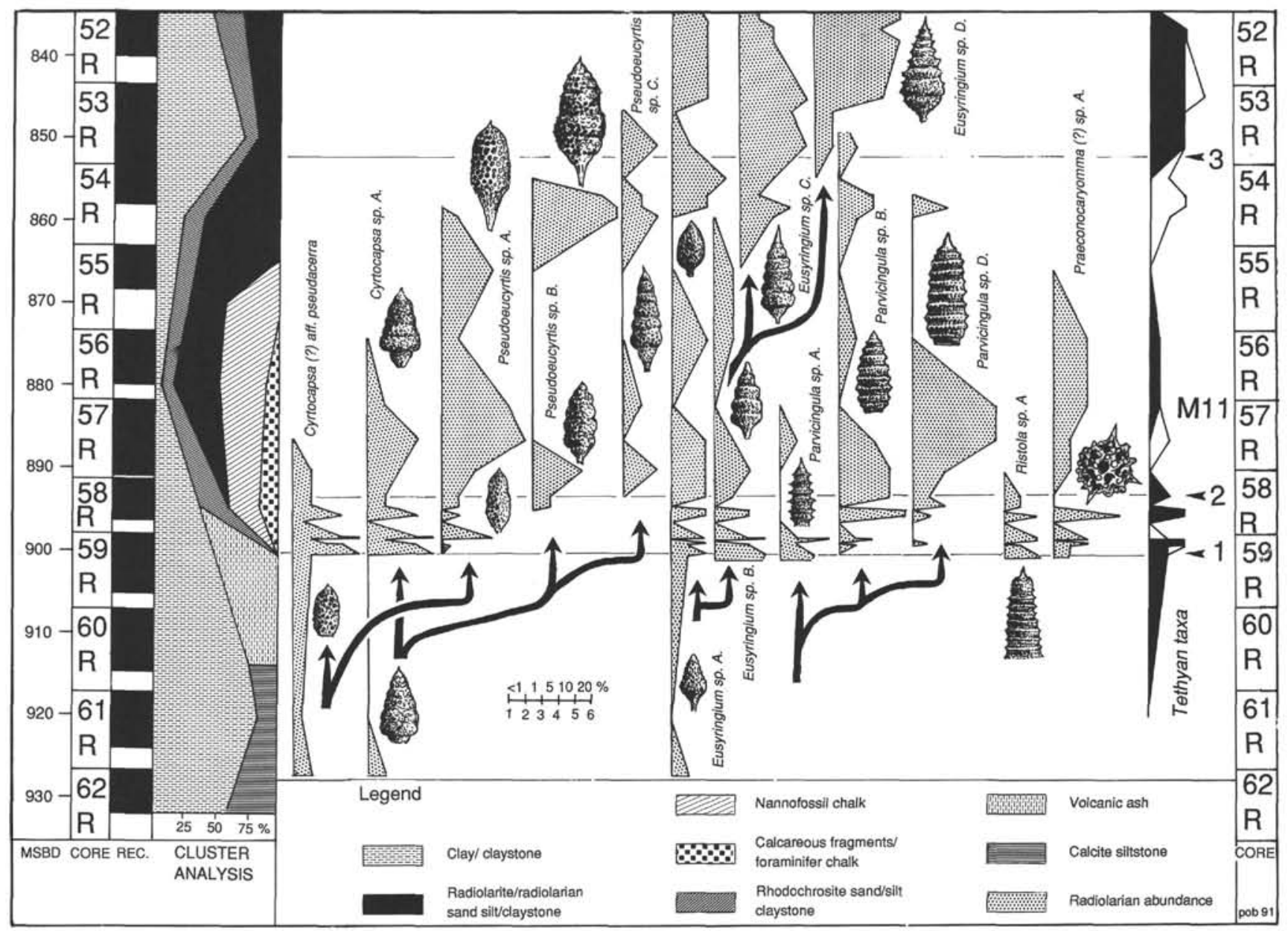

Figure 3. Plot of abundance vs. depth of selected Neocomian radiolarian species in Hole 765C, Cores 123-785C-62R through 52R. Scale ranges from 0 to 6 and definition of values is the same as for Table 2. The illustrated radiolarians are representative for the level where they are placed. The heavy lines with arrows show possible evolutionary relationships. The column "cluster analysis" (taken from Ludden, Gradstein, et al., 1990, Chapter 4, Pl. 2) shows lithologic variation vs. depth. Left column shows bulk abundance of "Tethyan" taxa (see discussion in the text) and three marked horizons. Below Horizon 1 radiolarian assemblages are of very low diversity and represent "clay faunas". Horizon 1 (Sample 138-765C059R-2, 96-98 cm) marks the onset of "sand faunas." Several species make their first appearance in several rapidly succeeding radiolarian sand layers. All the plotted species are unknown from tethyan sequences. Their high abundance above Horizon 1 is interpreted here as an sudden pulsating influx of southern high-latitude waters carrying "cirumantarctic" radiolarians into the Argo Basin. Between Horizon 2 and 3 (between Sample 765C-58R-3, $89-93 \mathrm{~cm}$ and Sample 765C-53R-5, $67-71 \mathrm{~cm}$ ) "tethyan" taxa are almost completely absent, whereas "circumantarctic" taxa show successive acmes of one or several species. This interval is interpreted as a time of strong influx of southern high-latitude waters that created cool water conditions, which excluded the presence of tethyan taxa. Above Horizon 3. (Sample 765C-53R-5, $67-71 \mathrm{~cm}$ ), tethyan taxa become more abundant, reflecting more equitable conditions due to a better paloceanographic connection to the Tethys Ocean. Lithologic variation closely matches faunal evolution: the interval between Horizons 1 and 3 is characterized by a comparably lower clay content, more margin-derived turbitites and current bedded lithologies with radiolarites, and nannofossil chalk. Magnetic Anomaly M11, which represents the time of oceanization between India and Australia, has been inferred on the basis of correlation of radiolarian acmes found at the bottom of the sedimentary section at Site 766.

trepter ranges higher here than elsewhere and then becomes extinct.

The last occurrence $(\mathrm{LO})$ of Obesacapsula verbana $(=O$. rotunda) was observed in Sample 123-765C-58R-3, 89-93 cm, indicating an age not younger than late Hauterivian. However, considering the late Berriasian or earliest Valanginian age of that sample, given by Kaminski et al. (this volume), this last occurrence seems to be a result of paleoceanographic change, rather than the top of a true range.

The lowest sample yielding determinable radiolarians was found in Sample 123-765C-62R-1, 53-56 cm. It shows the presence of Holocryptocanium barbui (sensu Baumgartner, 1984b), indicating an age not older than late Tithonian-Berriasian. $H$. barbui is generally known to range from early Albian to early Cenomanian (Schaaf, 1985; Sanfilippo and Riedel, 1985), but was found by Baumgartner (1984b) to range down to his Unitary Association 12, which is dated as late Berriasian in locality 46 of Baumgartner (1984b; Trattberg, near Salzburg, Austria).

\section{Radiolarians at Site 766}

Site 766 of Leg 123 is located at the base of the western Exmouth Plateau in a water depth of $4008 \mathrm{~m}$. One hole drilled at the site penetrated a sedimentary section that was Pleistocene to late Valanginian-early Hauterivian in age. A condensed Cenozoic sequence spans Cores 123-766A-1R through 123-766A-10R and contains several significant hiatuses. The presence of both fora- 
miniferal and nannofossil cool-water indicators suggests a temperate or middle latitude position of this site for much of the Cenozoic. The Mesozoic section is more complete and spans Cores 123-766A-10R through 123-766A-49R. A particularly thick Hauterivian section is present.

Radiolarians provide useful markers in the Pleistocene and Albian through Valanginian sections. Palynomorphs provide the most accurate biostratigraphic dating from the Barremian to the base of the hole. Dinoflagellates yield a late Valanginian-early Hauterivian age for sediment directly above and between diabase sills that were interpreted as basement. This study is based on the examination of all core-catcher samples plus additional samples selected during normal sampling of the cores (a total of 65 samples were studied). Bulk radiolarian abundance and preservation of all samples recovered at Site 766 are given in Table 3. Preliminary abundances of observed taxa for some selected samples are given in Table 5.

Lower Cretaceous radiolarians recovered from Cores 123$766 \mathrm{~A}-18 \mathrm{R}$ through Core $49 \mathrm{R}$ are poorly to moderately preserved, except for the interval of Cores 123-766A-22R through $25 \mathrm{R}$, which is characterized by a scattered high abundance of radiolarians concentrated in siliceous mudstone and scattered chert.

The interval between Samples 123-766A-22R-CC and 123766A-24R-CC was assigned to the lower Sethocapsa euganea Zone (Schaaf, 1985). Recorded species include Stichocapsa perspicua (= Sethocapsa euganea), ?Parvicingula malleola, and Eucyrtis micropora. The FO of ?P. malleola was observed in Sample 123-766A-23R-CC, and the LO of Alievum helenae,, co-occurring with rare $S$. euganea, was recorded in Sample 123$766 \mathrm{~A}-24 \mathrm{R}-\mathrm{CC}$. These associations indicate an age near the Barremian/Aptian boundary, probably in the lowermost Aptian for Sample 123-766A-24R-CC.

Sample 123-766A-25R-CC has no $S$. euganea and ?P. malleola, but contains Pseudodictyomitra lilyae and Parvicingula sp., indicating a probable Barremian age.

Sample 123-766A-28R-CC is characterized by the dominance of Eusyringium sp. D. A similar acme of this form was observed at Site 765 in Cores 123-765C-50R to $-52 \mathrm{R}$. In addition, this sample shows the FO of E. columbaria, which indicates a Barremian age. Cores 123-766A-29R through -30R yielded similar, but less well-preserved, assemblages that were dominated by spindleshaped forms of Eusyringium spp.

Cores $123-766 \mathrm{~A}-31 \mathrm{R}$ through $-4 \mathrm{R} 8$ yielded poorly preserved indeterminate inner casts of radiolarians.

Two samples in Sections 123-766A-49R-3 and -49R-4, from sediment layers between basalt sills, yielded a moderately preserved assemblage that included Eucyrtis micropora, Praeconocaryomma sp. aff. P. prisca, and other Praeconocaryomma spp., as well as Parvicingula sp. B and sp. D, known from Site 765, Cores 123-765C-57R to -59R. The presence of $P$. sp. aff. $P$. prisca indicates a late Valanginian age for the lowermost sediment at Site 766.

\section{TAXON QUANTITATIVE ANALYSIS AT SITE 765 (WITH REFERENCES TO SITES 261 AND 766)}

The excellent preservation and density of radiolarian samples at Site 765 , Cores $123-765 \mathrm{C}-42 \mathrm{R}$ through $62 \mathrm{R}$ and the striking difference among radiolarian assemblages recovered from claystones and radiolarian sand layers, called for a more quantitative approach that would more accurately illustrate these faunal differences. In addition, the rare occurrence of Tethyan taxa and the occurrence and faunal change of any unknown non-Tethyan taxa was quantified.

\section{Radiolarian Occurrence and Lithology}

The studied Neocomian radiolarian assemblages occur principally in three successive lithologic settings, each of which has typical abundances, preservation, and faunal composition. From the base of the sedimentary section (Core 123-765C-62R) to Sample 123-765C-59R-2, $121 \mathrm{~cm}$, scattered radiolarians are disseminated in claystones. Most of these assemblages are poorly preserved, have low abundance (Fig. 2), and are low in diversity. They contain a few species that are either endemic to the Argo Basin or have migrated in from the south, along with a few probably ecologically tolerant species (see clay faunas below).

Between Sample 123-765C-48R-7, $9 \mathrm{~cm}$, and $-59 \mathrm{R}-2,98 \mathrm{~cm}$, radiolarians are both disseminated in the dominant claystones and occur in interbedded sandy layers composed of radiolarians, fine detrital quartz, and/or rhodochrosite spherules. These layers are radiolarites that are composed of between $20 \%$ and $60 \%$ radiolarians. They probably resulted from periodically fluctuating bottom currents that winnowed and redistributed the radiolarians. Some of these beds may represent low density turbidites. Substantial differences in radiolarian assemblages, discussed in detail below, can be observed between the claystones and the radiolarite layers. Radiolarians are abundant in the sand layers and rare to common in the claystones. Abundance and preservation curves (Fig. 2) show a maximum toward the base of the interval (Core 123-765C-59R) and decrease steadily upsection until Core 123$765 \mathrm{C}-55 \mathrm{R}$. This decrease parallels the decrease in abundance of radiolarite layers in that interval (Ludden, Gradstein, et al., 1990). Both phenomena probably were caused by an increasing influx of margin-derived turbidites (Dumoulin and Bown, this volume) that diluted the claystone-radiolarite sedimentation. Tethyan forms are rare in Cores $123-765 \mathrm{C}-59 \mathrm{R}$ to $-58 \mathrm{R}$ (Fig. 3) and are virtually absent from Cores $123-765 \mathrm{C}-57 \mathrm{R}$ to $-54 \mathrm{R}$. They reappear gradually and gain in importance starting in Core 123-765C-53R. Non-Tethyan forms totally dominate the sand faunas. Their occurrence and faunal change are discussed in detail below. Preservation and abundance reach a broad maximum in Cores 123$765 \mathrm{C}-52 \mathrm{R}$ to $-50 \mathrm{R}$, then decrease to zero in Core $123-765 \mathrm{C}-48 \mathrm{R}$. Above Core 123-765C-48R, radiolarians are disseminated in claystones and in sand layers that are composed of mostly rhodochrosite micronodules. The contrast between sand and clay faunas gradually diminishes up the section, as Tethyan taxa become more important in number and diversity. This was also observed at Site 766 and is true for other fossil groups: plankton communities become gradually more cosmopolitan during the early Aptian.

\section{Specific Composition and Paleoecology of Clay Faunas}

\section{Occurrence and Preservation}

Claystone in shades of red and gray is the dominant lithology of the upper Tithonian-Berriasian to lower Aptian portion of Hole $765 \mathrm{C}$ and also of DSDP Site 261. Unlike the radiolarites and other interlayerd minor lithologies, the claystones are featureless and appear homogeneous. They contain small amounts of radiolarians, which can be observed on the cut core surface as small white specks. During shipboard sampling, it seemed reasonable to take most of the samples for radiolarian studies from the radiolarite layers. Clay samples thus are largely underrepresented in our data base. The volume of radiolarian residue washed from a claystone never exceeded $2 \%$ of the sample volume and often was less than $1 \%$. The claystone assemblages discussed here are found in Cores 123-765C-59R through -49R, and Site 261 Cores 30 to 23 . Above these cores, the contrast between clay and sand 
assemblages disappears gradually, and all recovered assemblages become more diverse (see below). Radiolarians of clay faunas are moderately to well-preserved (they are clay-filled). In comparison to sand faunas of Site 765 , preservation is better in the claystones, probably because of a less intense diagenesis owing to tight molding by clays. Abundance is low to very low, and diversity is also very low. Typical clay faunas were found at Site 765 in the following samples, listed in Table 2: 123-765C-59R-2, 121-125 $\mathrm{cm}$ (see Pl. 1, Fig. 1), 123-765C-50R-3, 111-115 cm, and 123765C-49R-3, 69-75 cm.

\section{Sedimentology}

Radiolarian specimens of clay faunas are small compared to average specimens in sand faunas. The simplest interpretation is to consider them as fines of current-deposited layers from which all coarser (heavier) material was separated by hydraulic sorting. This interpretation is contradicted by several observations. Clay faunas contain inoceram prisms and quartz grains, which have a much higher bulk density than radiolarians and are hydrodynamically equivalent to much larger species. On the other hand, sand faunas are more diverse and contain a variety of small forms and fragments of large forms (see Pl. 1, Figs. 2 and 3) that are hydrodynamically equivalent to clay species, but absent from the clay samples. Additional evidence against a hydrodynamic origin of the faunal contrast between clays and sands is the near-total absence of sand faunas from Site 261, Cores 30 to 23. Dumoulin and Bown (this volume) argue that an important proportion of the claystones may have been current reworked and were deposited by mass flows at both Sites 765 and 261. This still does not explain the absence of sand faunas at Site 261. It is difficult to imagine that radiolarian species originally present in this area would have been totally removed from that area by hydrodynamic processes. Sand faunas seem to be restricted to sites near the Australian margin and, in contrast with the clay faunas, may not be indigenous to the Argo Basin (see below).

\section{Specific Composition}

Dominant species groups in the clay faunas are Archeodictyomitra brouweri s.I. (more than 20\%, up to 50\%) and cryptocephalic and cryptothoracic nasellarians (more than 20\%, sometimes more than 50\%). Among the latter group, Holocryptocanium barbui barbui and Cryptamphorella sp. A are abundant. The remainder of the assemblages is composed of Tricolocaspsa spp., Sethocapsa spp., and some other small nassellarians. At Site 261 , Cores 30 to 23 , the faunal composition is similar (Renz, 1974; Table 5). The observed species are known from the Tethys, the Atlantic and Pacific oceans, and from Roti (Timor). However, these species occur there in much lower abundance and in significantly more diverse assemblages. The species found in the Argo Basin may represent ecologically tolerant, cosmopolitan forms. Typical Tethyan forms such as Pantanellium spp. are totally absent, as are most of the other non-Tethyan species that dominate the sand faunas.

\section{Interpretation}

I interpret the clay faunas as the autochthonous, oceanic faunal association, in contrast to the sand faunas, which clearly have been current transported and may have come from outside the studied area (see below). The recorded species are known from Tethys and elsewhere (but not from southern high latitudes, Ling and Lazarus, 1990) and seem to be ecologically tolerant or opportunistic. The number of taxa in the clay faunas is about 10 to 20 times lower than in typical Tethyan assemblages (e.g., Oman, Umbria; Jud, 1989; Baumgartner, pers. data). Diversity is still two to three times lower than in the coeval sand faunas. Similar low diversities have been reported from the Kimmeridge Clay of the North Sea (Dyer and Copestake, 1989). Modern radiolarian faunas of such low diversity have been reported only from fjords (Aarseth et al., 1975). They are indicative of particular conditions in a basin that has been paleoceanographically isolated.

\section{Sedimentology, Specific Composition, and Paleobiogeography of Sand Faunas}

\section{Occurrence and Preservation}

Distinct radiolarite intervals occur in the Berriasian to Barremian interval at Site 765. Between Samples 123-765C-48R-7, $9 \mathrm{~cm}$, and $-59 \mathrm{R}-2,98 \mathrm{~cm}$ (95 m of section), sand- to silt-sized radiolarians form more than 100 conspicuous, white, greenishgray, gray, and green radiolarite layers that range typically from a few millimeters to $2 \mathrm{~cm}$ thickness, but may be as much as $15 \mathrm{~cm}$ thick. These radiolarites constitute less than $5 \%$ of the total sequence. Radiolarians constitute $20 \%$ to $60 \%$ of these layers. Sedimentary structures are common. Lower contacts are scoured or sharp, and upper contacts are sharp or gradational to clayey siltstone with radiolarians. Some intervals are normally graded, whereas others appear reversely graded; most have parallel and/or wavy laminations. Some may represent starved ripples. Section 123-765C-54R-1, $70 \mathrm{~cm}$, displays a complex graded interval of superposed coarsening- and fining-upward sequences. In Section 123-765C-57R-4, radiolarite laminae occur at several intervals within a 0.5 -m-thick fining-upward sequence of calcareous chalk. Radiolarites increase in abundance and thickness downward from Core 123-765C-55R, where they constitute a few millimeter-thick layers, to Core $123-765 \mathrm{C}-57 \mathrm{R}$, where more than 10 discrete intervals as much as $8 \mathrm{~cm}$ thick can be discerned. Radiolarites contain minor amounts of sponge spicules, quartz silt, clay, and/or rhodochrosite micronodules and inoceramid prisms (at the base of the sedimentary section). Radiolarians in sand faunas are usually filled with chalcedony and are often less well-preserved than those of clay faunas as a result of more vigorous diagenesis in a grain-supported, permeable sediment composed of biogenic silica. The occurrence of abundant radiolarite layers (with their characteristic sand faunas) is unique to Site 765 . At Site 261, only one sample $(261-27-2,70-73 \mathrm{~cm})$ out of 34 treated samples from the Late Jurassic-Barremian interval yielded species typical for sand faunas. In Cores 261-22 and 261-21, some millimeter-sized radiolarian laminae occur. These contain mixed Tethyan and non-Tethyan faunas. At Site 766, sand faunas do occur and show some of the acmes observed at Site 765. However, biogenic sediment is greatly diluted by detrital influx from the nearby Exmouth Plateau.

\section{Sedimentology}

The above characteristics clearly indicate redeposition and concentration of radiolarians by hydrodynamic processes; e.g., winnowing bottom currents, contour currents, or for some of the layers, low-density turbidity currents. Some of the radiolarite layers form part of the Bouma sequences that are mainly composed of calcareous silt and claystone (Dumoulin and Bown, this volume). Similar radiolarite sands were described from the western Atlantic, near the Bermuda Rise (Leg 43, Site 386, Tucholke, Vogt, et al., 1979). McCave (Tucholke, Vogt, et al., 1979) suggested that deposition of the radiolarian sand beds occurred during "long blooms" and subsequent bottom current winnowing. Of course, there is no comparison to Tethyan Mesozoic ribbon radiolarites, which have thicknesses of tens to hundreds of meters: at Hole $765 \mathrm{C}$, for $80 \mathrm{~m}$ of the section between Cores $-58 \mathrm{R}$ and $-51 \mathrm{R}$, shipboard scientists found a maximum of $3.5 \mathrm{~m}$ of radiolarite, with silica contents as high as $85 \%$ to $100 \%$. 


\section{Specific Composition}

Radiolarian abundance in sand faunas is high, while diversity is two to three times higher than for clay faunas but still five to 10 times lower, compared to Tethyan assemblages. Species typical of the clay faunas (i.e., cryptocephalic and cryptothoracic nassellarians and Archaeodictyomitra spp.) form a constant background in sand assemblages that typically ranges from $10 \%$ up to $40 \%$. An exception are some conspicuously winnowed assemblages (e.g., Samples 123-765C-57R-CC and -57R-1, 67-70 cm; see Pl. 1, Fig. 6), which contain only larger forms. Non-Tethyan forms totally dominate the sand faunas. Plates 1 and 2 illustrate a number of residues to visualize the striking difference between assemblages from the Argo Basin and from Tethys, as well as the rapid faunal change through the section. Each core contains a characteristic assemblage. Figure 3 graphically represents abundances and possible evolutionary links between some species.

Below Sample 123-765C-59R-2, 96-98 cm, some non-Tethyan species found uthe psection in sand faunas are present: $C y r$ tocapsa (?) sp. aff. C. pseuacerra, Cyrtocapsa sp. A., and Eusyringium sp. A. are rarely found at Site 765 and are only traces at Site 261, Core 29. These forms are certainly southern mid- to high-latitude forms. Either they may have migrated through the already marine, rifted zone beween Australia and India or they are endemic to the Argo Basin. In Sample 765C-59R-2, 96-98 cm (Fig. 3, level 1), a number of species make their sudden appearance in the first sand fauna: Eusyringium sp. B, Parvicingula sp. A, Praeconocaryomma(?) sp. A. and Ristola sp. A. In the following samples of Cores 123-765C-59R and -58R, a rapid succession of first appearances in high abundances was observed (Fig. 3); these include Pseudoeucyrtis sp. A and B and Parvicingula sp. B and $\mathrm{C}$.

The interval between Sample 123-765C-59R-2, 96-98 cm, and Sample 123-765C-58R-3, 89-93 cm (Fig. 3, between levels 1 and 2 ) is characterized by strong fluctuations of taxon abundances and by a presence of rare Tethyan species. The same interval shows the sharp onset of calcareous, margin-derived turbidites (Dumoulin and Bown, this volume), which is well reflected by smear slide data (Fig. 3; Ludden, Gradstein, et al., 1990). There is no doubt that this interval records a major change in the paleoceanography of the Argo Basin (see below).

Above Sample 123-765C-58R-3, 89-93 cm (Fig. 3, level 2) Tethyan species disappear almost completely, and non-Tethyan species launch a series of well-defined acmes (Fig. 3) that give each core a characteristic radiolarian signature. Some of these acmes can also be observed at Site 766. Few-to-common Parvicingula sp. B, few-to-dominant $P$ arvicingula sp. D, and commonto-dominant Praeconocaryomma (?) sp. aff. $P$. prisca characterize Core 123-765C-57R (Table 2). This association is present at Site 766 in Samples 123-766A-49R-4, 23-26 cm, and 49R-3, $92-94 \mathrm{~cm}$, both interbedded between phyric basalt sills that are considered as part of the basement. Palynomorphs and nannofossils of Cores 123-766A-49R and -50R date the same interval as late Valangian. This gives an excellent tie to the assemblages in the Argo Abyssal Plain: the onset of sand faunas at Site 765 pre-dates the late Valanginian oceanization of the Indo-Australian rift (see below). Eusyringium sp. D makes its acme at Site 765, Cores 123-765C-53R-1 to -51R-2. The same acme occurs at Site 766 in Sample 123-766A-28-CC. At Site 261, only one sample (261-27-2, 70-73 cm) yielded abundant Parvicingula sp. B and few Eusyringium $\mathrm{sp}$. A. that might correspond to the associations observed in Core 123-765C-54R. However, this correlation is preliminary.

Beginning with Sample 123-765C-53R-5, 67-71 cm (Fig. 3, level 3 ), Tethyan forms gradually reappear and become more and more important in abundance and diversity until Core 123-765C-
$42 \mathrm{R}$, while non-Tethyan forms still largely dominate this interval. Successive acmes of Eusyringium sp. C (Core 123-765C-53R), E. sp. D (Cores 123-765C-52R to -51R), Parvicingulid sp. A (Cores 123-765C-45R to -43R), Parvicingulid sp. C (Core 123-765C$50 \mathrm{R}$ to $-43 \mathrm{R}$ ) and Parvicingulid sp. D (Core 123-765C-42R) can be observed (Fig. 3, Table 2).

\section{Paleobiogeography and Interpretation of Sand Faunas}

None of the non-Tethyan species recovered from the sand faunas are known from any other area. Very similar forms of Parvicingula and Ristola have been reported by Aita from the green argillites of Tawhitokino Beach, Kawakawa Bay Auckland, New Zealand (Spörli and Aita, 1988). Similar Parvicingula species also occur in the Middle Jurassic of the Blue Mountains, Oregon (Pessagno and Whalen, 1982), and in the Late Jurassic part of the Great Valley Sequence that overlies the Coast Range Ophiolite in California (Pessagno, 1977a; Pessagno et al., 1984). Boreal Late Jurassic-Early Cretaceous localities of the Soviet Union (Vishnevskaya, 1988) may contain similar faunas, but remain to be studied in detail. "Parvicingula"-type forms dominate largely over "Ristola"-type forms in the sand faunas. (In the sense of Pessagno and Whalen, [1982], the genus Ristola differs from Parvicingula by the absence of a cephalic horn. Ristola sp. $A$ in this chapter bears a cephalic horn and should be attributed to Parvicingula by Pessagno and his collaborators. However, I use the original definition of Ristola [Pessagno, 1977a; Baumgartner, 1984b], see "Taxonomic Listing" section [this chapter].) Pantanelliids are absent from claystone assemblages and are rare in sand assemblages.

Pessagno and Blome (1986) suggested that high abundance and diversity of pantanellids and common occurrence of "Parvicingula"-type nassellarians characterize the "northern Tethyan" faunal realm, whereas total absence of pantanellids and "Ristola"type forms characterize the Boreal realm. I have interpreted (Baumgartner, 1987) this faunal provincialism as an expression of the degree of paleoceanographic restriction of Mesozoic basins that is controlled not only by latitude, but also by a number of other paleoceanographic factors, such as basin geometry and oceanic current settings. Apart from an Aptian/Albian radiolarian fauna recently reported by Ling and Lazarus (1990) from the Weddell Sea (Hole 693B) and the poorly preserved faunas from New Zealand mentioned above (Spörli and Aita, 1988; Spörli et al., 1989), no Early Cretaceous southern mid- to high-latitude radiolarians are known. Therefore, it is premature to define an austral radiolarian faunal province. The characteristics of the non-Tethyan sand faunas, however, match well with those of northern high-latitude faunas. An origin of the sand faunas in southern high-latitudes seems a logical consequence, if one assumes bipolar similarity of radiolarian faunas as it exists in the Neogene and today (e.g., Nigrini, 1967).

The sedimentology of the radiolarite layers dicussed above and the near absence of these layers at the more distal Site 261 clearly indicate that the non-Tethyan radiolarians in the sand faunas were deposited near the Australian margin and are not indigenous to the Argo Basin. In an earlier study (Ludden, Grastein, et al., 1990), I interpreted these faunas as being penecontemporaneously displaced from an area of possible upwelling near the continental slope. However, modern upwelling assemblages do not contain endemic species, but reflect the faunal composition of the basinal water masses from which the upwelling waters are derived (Casey, 1971). Because the sand faunas are different from autochthonous basinal clay faunas, the former have to come from outside the basin. Inception and evolution of endemic radiolarians (as observed in the sand faunas) can only take place in sufficiently large, specific oceanic water masses (Casey, 1971). By using an initial fit of Gondwana (Fig. 4A) as proposed by Ricou et al. 


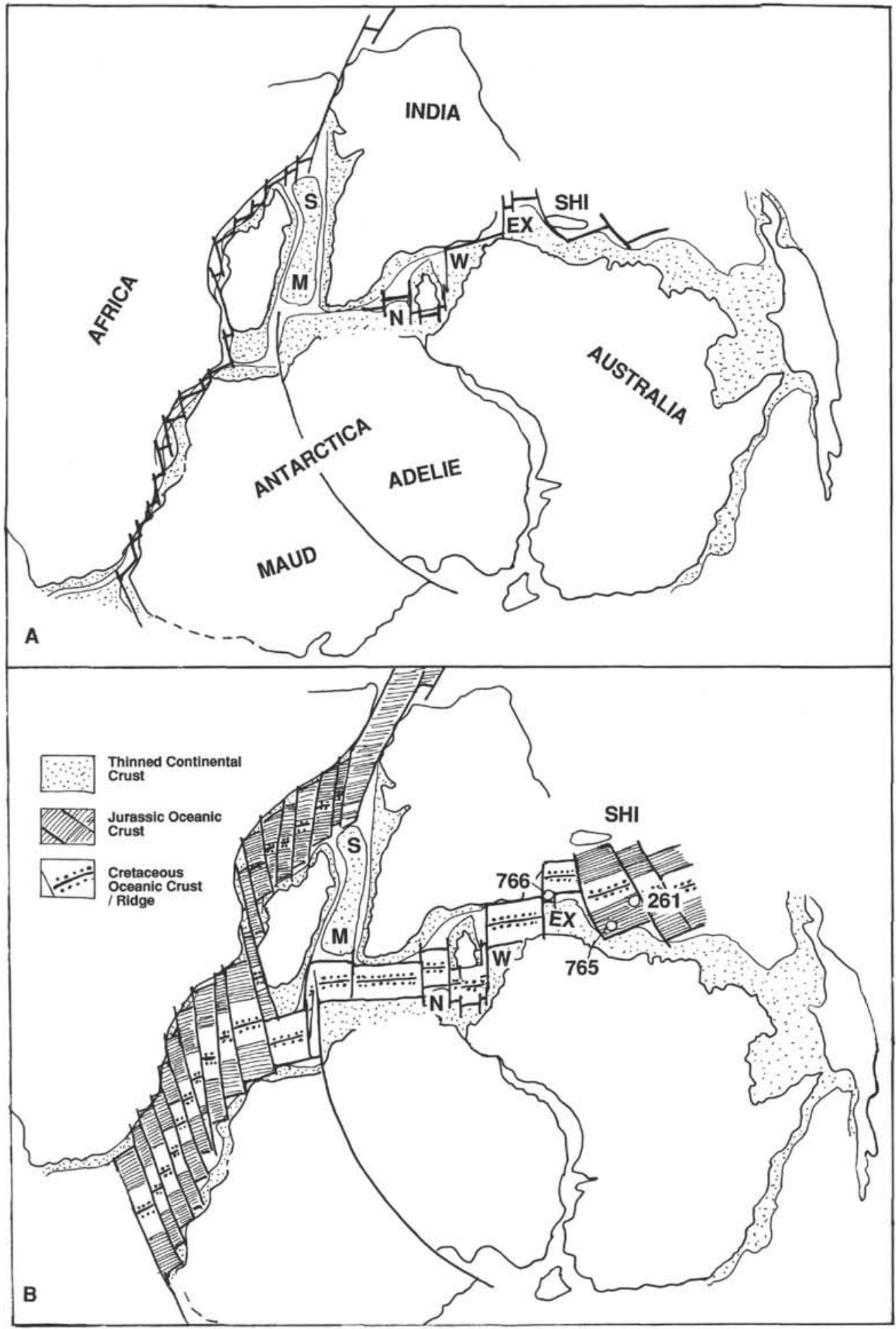

Figure 4. A. Initial fit of Gondwana as proposed by Ricou et al. (1990). These authors propose to split Antarctica into two parts (named Adelie and Maud) to obtain a closure of all gaps within the megacontinent. Areas underlain by (thinned) continental crust are stippled: Seychelles-Mascareignes ( $-\mathrm{M}$ ), Naturaliste Plateau (N), Wallaby Plateau (W), and Exmouth Plateau (EX). An individual continental block opposite to Northwest Australia, the Shillong Hills (SHI) is assumed. This fit and its Jurassic-Early Cretaceous breakup (B) is more consistent with the radiolarian data presented here than a fit of DuToit-type. B. Jurassic-Early Cretaceous breakup of Gondwana constructed with paper and scissors for the purpose of paloceanographic reconstructions. It does not necessarly coincide with a solution mentioned by Ricou et al.(1990). A Jurassic breakup is assumed for the Somali Basin, between South Africa and Antarctica and in the Argo Basin. An Early Cretaceous breakup separates India from Antarctica and Australia. The location of Sites 765 and 766 and DSDP Site 261 are indicated. 
(1990), and by assuming a Late Jurassic and Early Cretaceous break-up of Gondwana (as shown in Fig. 4B), such an oceanic space can be created around part of Antarctica and may have hosted a proto-circumantarctic current system. Casey (1971) showed that the California Current off southern California transports northern high-latitude radiolarians into the temperate realm, where they upwell and undergo mass mortality because of unfavorable conditions. These exotic faunas form a major portion of the surface sediment assemblage deposited during the (seasonally variable) activity of the California Current. A similar scenario can be inferred for the Argo Basin: as soon as the rift zone between India and western Australia became deeper marine and then oceanic, southern high-latitude water masses were forced by a protocircumantarctic current system into these straits to carry circumantarctic radiolarian species into the Argo Basin (Fig. 5). This hypothetical cold-water current entered the Argo Basin via the Exmouth Plateau and contoured the northwestern Australian continental slope. Upwelling, triggered by the current itself or by offshore winds brought the cold-water forms in contact with temperate surface waters, which caused their death, sinking, and concentration by bottom currents induced by the same cold-water contour current. Fluctuations in cold-water influx through the Indo-Australian straits created fluctuations in radiolarian influx and concomitant bottom current activity that resulted in the conspicuous radiolarian layers of Site 765 .

\section{PALEOCEANOGRAPHIC AND PLATE-TECTONIC SCENARIOS}

\section{Tithonian-Late Berriasian}

During the Tithonian and Berriasian (Fig. 3, between levels 1 and 2), spreading widened the Argo Basin, a narrow embayment limited to the north by the Shillong Block and to the south and west by the present-day northwestern Australian margin (Fig. 4). Paleoceanographic conditions were restricted and permitted only the existence of a few tolerant radiolarian species. These are known from Tethys and elsewhere, but apparently not from high latitudes (Ling and Lazarus, 1990). The low-diversity radiolarian assemblages that are found disseminated in claystones reflect conditions similar to those in present-day fjords (Aarseth et al., 1975), or alternatively, represent central gyre, low-fertility conditions.

During the same time, spreading broke up Gondwana and opened up an oceanic space between Africa, Antarctica, and western India, creating a significant oceanic water mass (the proto-Antarctic Ocean). It hosted an endemic radiolarian fauna derived from northern high- and low-latitude ancestors that migrated into the area. A few species, unknown from Tethys, but found in small quantities in the Argo Basin during this period may have migrated from the proto-Antarctic Ocean through the developing Indo-Australian rift zone as soon as deeper marine conditions prevailed.

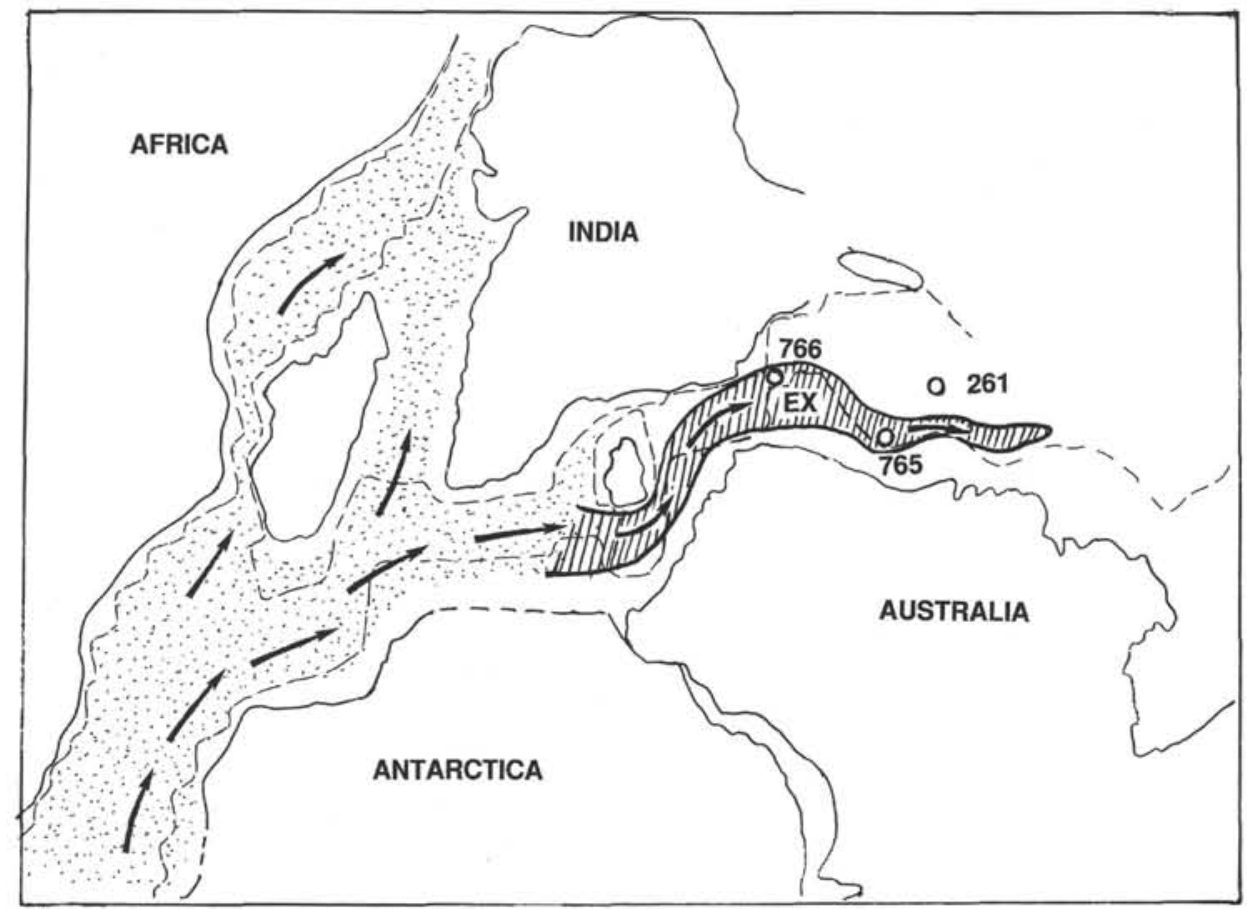

Figure 5. Gondwanian paleogeography during the Early Cretaceous (Hauterivian), deduced from Figure 4. Stippled lines indicate inferred $2000 \mathrm{~m}$ isobath. Jurassic and Early Cretaceous breakup led to oceanic seaways that isolated an Antarctic-Australian continental mass, favoring a clockwise proto - circumantartic current system (arrows). Following the Valanginian (M11) breakup between Australia and India, circumantarctic cold-water masses flowed towards the North, contouring the Northwest Australian margin (heavly hachured area). These water masses carry cicumantarctic radiolarian faunas from their origin (stippled area) into the warmer Argo Basin. Periodical upwelling along the margin may have led to mass extinctions of these faunas and created abundant radiolarian sediment, which was then reworked by bottom currents to form the radiolarite layers observed at Sites 765 and 766 (but not at Site 261). 


\section{Late Berriasian-Early Valanginian}

The late Berriasian-early Valanginian (Fig. 3, between levels 1 and 2) is characterized by unstable paleoceanographic conditions in the Argo Basin, triggered by the Indo-Australian break-up and a hypothetical ice age (see below). Although the first oceanic crust in the Indo-Australian straits did not form until the late Valanginian (M11), the rift zone and the adjacent margins were submerged deeply enough to permit an intermittent "spillover" of circumantarctic cold water into the Argo Basin, creating a current that contoured the Australian margin. Cold-water radiolarians periodically were transported in and upwelled along the margin. Upon coming in contact with temperate surface waters, they died en masse. Their skeletons sank and became concentrated by winnowing bottom currents periodically reenforced by a coldwater influx from the south. Greatly increased pelagic turbidite influxes from plateaus bordering the Argo Basin during this time have been interpreted by Dumoulin and Bown (this volume) as the result of increased erosional activity of bottom currents along the margins in the context of two pronounced lowstands in sea level (Haq et al., 1988) during this time interval. Both lowstands have been recognized worldwide and exceed $100 \mathrm{~m}$ in amplitude (Haq et al., 1988). Hypothetically, they may have been caused by an antarctic glaciation that built up inland ice on the AntarcticAustralian continent when, for the first time, oceanic seaways separated Antarctica and Australia from the remainder of Gondwana. A proto-circumantarctic current system may have developed and created a polar cold-cell, which led to glaciation. Although no direct observations pertaining to such a glaciation are known, growing evidence for an Early Cretaceous cooling of global climate and for major environmental changes during the late Berriasian-Valanginian (Weissert and Lini, in press) does exist. The high rate of change in taxon composition and abundance observed in Cores 123-765C-59R and -58R reflects highfrequency fluctuations of oceanic currents and biogenic influx; this may actually represent prime evidence for rapid climatic changes, typical for ice ages, in the Southern Hemisphere during the Early Cretaceous.

\section{Late Valanginian-Late Hauterivian}

The late Valanginian to late Hauterivian period (Fig. 3, between levels 1 and 2) encompasses the oceanization of the IndoAustralian break-up (M1 1, late Valanginian) and its rapid widening. As a consequence, cold-water influx into the Argo Basin became more steady and strengthened during this period. This influx probably affected the entire Argo water mass to the extent that typical Tethyan radiolarian species are virtually nonexistant, except for a few tolerant ones. Well-defined successive acmes of circumantarctic species transported in from the south reflect several evolutionary lineages unknown from Tethys and may characterize a southern high-latitude faunal realm that was well established by that time. The significance of reworking of pelagic carbonate from the plateaus to the Argo Basin floor by turbidites increased and reached a maximum toward the later part of this period, then sharply decreased just before its end.

\section{Barremian-Early Aptian}

The Barremian-early Aptian interval (Fig. 3, above level 3) shows continued influx of circumantarctic cold-water radiolarians, which dominate the radiolarian faunas well into the Aptian, where their occurrence becomes spotty. Meanwhile, the connection to southern Tethys was well established and as a consequence, more and more typically Tethyan species appear in the Argo Basin sediments. More equitable climatic conditions that prevailed during the late Barremian and earliest Aptian may have resulted in weakened upwelling, which is responsible for a less- continuous radiolarian record. Intermittent peak abundance and good preservation occur nevertheless during the early Aptian and might be related to the early Aptian lowstand in sea level (Haq et al., 1988).

\section{SUMMARY AND CONCLUSIONS}

The Berriasian-early Aptian radiolarian record recovered at Site 765 is unique in its density of well-preserved samples and in its faunal contents. Radiolarian assemblages recovered from claystones are unusual because of their very low diversity of apparently ecologically tolerant species and contrast with faunas found in radiolarite layers. Comparisons with Sites 766 and 261 as well as sedimentological observations lead one to conclude that this faunal contrast resulted from a difference in provenance, rather than from hydraulic sorting.

Biostratigraphic dating proved difficult principally because of the paucity, or even absence, of (Tethyan) species used in published zonations. In addition, published zonations are contradictory and do not reflect total ranges of species.

Radiolarian assemblages recovered from claystones at Sites 765 and 261 in the Argo Basin reflect restricted oceanic conditions for the Latest Jurassic to Barremian time period. Neither the sedimentary facies nor the faunal associations bear any resemblance to sediment and radiolarian facies observed in Tethyan sequences. I conclude that the Argo Basin was paleoceanographically separated from Tethys during the Late Jurassic and most of the Early Cretaceous by a higher paleolatitude and by enclosing landmasses (i.e., northeast India and the Shillong Block, which were adjacent to the northwestern Australian margin before the opening; Fig. 4).

Assemblages recovered from radiolarite layers are dominated by non-Tethyan species that have been interpreted here as circumantarctic. Their sudden appearance in the late Berriasian predates the oceanization of the Indo-Australian break-up by about 5 m.y., but coincides with a sharp increase in margin-derived pelagic turbidites. The Indo-Australian rift zone and adjacent margins were probably submerged deeply enough to permit an intermittent "spillover" of circumantarctic cold water into the Argo Basin, creating increased bottom current activity. Circumantarctic cold-water radiolarians transported into the Argo Basin upwelled along the margin and died en masse. Concommittant winnowing by bottom currents led to their accumulation in distinct radiolarite layers. High rates of faunal change and the sharp increase of bottom current activity are thought to be synchronous with the two pronounced late Berriasian-early Valanginian lowstands in sea level (Haq et al.,1988). Hypothetically, both phenomena may have been caused by a glaciation on the AntarcticAustralian continent that for the first time is isolated from the rest of Gondwana by oceanic seaways (Fig. 4).

The absence of typical Tethyan radiolarian species during the late Valanginian to late Hauterivian period has been interpreted as a time of strong influx of circumantarctic cold water (Fig. 5), following oceanization (M11) and rapid spreading of the IndoAustralian break-up.

The reappearance and gradual increase in abundance and diversity of Tethyan forms along with the still-dominating circumantarctic species are thought to result from more equitable overall climatic conditions during the Barremian and early Aptian and may be due to the establishment of an oceanic connection with the Tethys Ocean during the early Aptian.

\section{TAXONOMIC LISTING}

\section{Explanatory Notes}

The purpose of this taxonomic listing is to present the most important synonymy and other information pertaining to the re- 
ported taxa as well as preliminary descriptions (with open nomenclature) of the non-Tethyan forms reported here for the first time.

Each taxon name is preceded by a four-digit taxon number that refers to the Mesozoic radiolarian data base in preparation (Jurassic-Cretaceous Working Group). These numbers are independent of the taxonomy; they stand for one or a group of morphotypes, usually defined by figures and descriptions, regardless of the formal or informal taxonomic status of the group.

This listing, Tables 2 and 4, and Plates 3 through 13 have been alphabetically ordered. In the plates, this order has been altered, where arrangement or space made it necessary. For each illustrated specimen, the sample level and a unique number (90/XXXX) are given. These numbers refer to the authors collection of SEM negatives.

Under "Occurrences," a statement of localities, from which a form is known, is made. For non-Tethyan forms, a paleobiogeographic interpretation is given that includes information about acmes.

Under "Range," published ranges are compared to ranges observed in the Indian Ocean or at Sites 765, 766, and 261 considered here. For most Tethyan species, considerable discrepancies exist between the two statements. Age designations at Site 765 have been based on ages given in Figure 2 that were taken from Kaminski et al. (this volume).

\section{TAXONOMY}

\section{Genus ACAENIOTYLE Foreman}

Acaeniotyle Foreman, 1973, p. 258.

Type species. Xiphosphaera umbilicata Rüst, p. 7, pl. 1, fig. 9.

\section{Acaeniotyle diaphorogona Foreman}

$$
\text { (Pl. 3, Fig. 1) }
$$

Acaeniotyle diaphorogona Foreman, 1973, p. 258, pl. 2, figs. 2-5; Foreman, 1975 , pl. $2 \mathrm{~F}$, figs. $1-3$, non figs. 4-5; pl. 3, figs. 1-2; Muzavor, 1977, p. 34, pl. 1, fig. 1; Mizutani, 1981, p. 175, pl. 61, figs. 1-2; De Wever and Thiebault, 1981, p. 582, pl. 2, fig. 7; Kanie et al., 1981, pl. 1, fig. 1; Aoki, 1982, pl. 1, fig. 1; Schaaf, 1984, p. 104-105, figs. 1-5. Acaeniotyle sp. aff. A. diaphorogona Foreman, 1973, pl. 2, fig. 6,7; pl. 16, fig. 16; Foreman, 1975, p. 607, pl. 1F, fig. 1; Yao, 1984, pl. 3, fig. 24.

Tripocyclia sp. aff. T. trigonum Rüst, Pessagno, 1977 a, p. 80, pl. 7, figs. 8,9 ;

Acaeniotyle diaphorogona Foreman s. 1., Baumgartner, 1984b, p. 753, pl. 1 , figs. 1,2 .

Occurrences. Tethyan, Atlantic, Pacific, Site 765: see Table 2. Range. Published: Oxfordian to middle Albian.

\section{Acaeniotyle umbilicata (Rüst)}

(Pl. 3, Fig. 2)

Xiphosphaera umbilicata Rüst, 1898, p. 7, pl. 1, fig. 9; Renz, 1974, p. 799, pl. 2, figs. 9-11, (?)12; pl. 9, fig. 21.

Spumellariinid Pessagno, 1969, p. 610 , pl. 4, fig. N.

Acaeniotyle umbilicata Rüst, Foreman, 1973, p. 258, pl. 1, figs. 12-14, 16; Foreman, 1975, p. 607, pl. 2E, figs. 14-17; pl. 3, fig. 3; Muzavor, 1977, p. 26, pl. 1, fig. 3; Nakaseko et al., 1979, pl. 4, fig. 7; Baumgartner et al., 1980, pl. 2, fig. 8; De Wever and Thiebault, 1981, p. 582 ; Kocher, 1981, p. 51, pl. 12, figs. 1, 2; Schaaf, 1981, p. 431, pl. 6 , fig. 11; pl. 15, figs. 3a, 3b; Nakaseko and Nishimura, 1981, p. 141, pl. 1, fig. 7; non pl. 14, fig. 2; Kanie et al., 1981, pl. 1, fig. 2; Baumgartner, 1984b, p. 754, pl. 1, fig. 5; Ozvoldova and Sykora, 1984 , p. 261 , pl. 1, figs. 4 , 5 ; Schaaf, 1984, p. 148-149, figs. 1, 2a-2b, 3a-3b; Sanfilippo and Riedel, 1985, p. 587, pl. 4, figs. 2a-2d; Aita and Okada, 1986, p. 108, pl. 1, fig. 1; De Wever et al., 1986, pl. 6, figs. 8, 12-13; Aita, 1987, p. 63, pl. 12, fig. 2; Pavsic and Gorican, 1987, p. 22, pl. 2, fig. 5; Kito, 1987, pl. 1, fig. 7; Ozvoldova, 1988, pl. 1, fig. 1; Taketani, 1982, pl. 1, fig. 1; Kato and Iwata, 1989, pl. 1, fig. 9.
Occurrences. Tethyan, Atlantic, Pacific, Indian Ocean. Site 765: Table 2.

Range. Published: Kimmeridgian to Albian.

6135 Acaeniotyle (?) sp. A (Pl. 3, Fig. 3)

Description, Remarks. Form with four pointed spines that show knobs like A. diaphorogona dentata Baumgartner, 1984b.

Occurrences. Tethyan, Site 765, Sample 123-765C-59R-2, 96-98 $\mathrm{cm}$.

3601 Genus Acanthocircus Squinabol emend. Donofrio and Mostler

Acanthocircus (Squinabol) Squinabol, 1903, p. 124; Donofrio and Mostler, 1978, p. 22.

Type species. Acanthocircus irregularis Squinabol, 1903, p. 125, pl. 9, fig. 6. (subsequent designation by Campbell, 1954, p. D106).

3065 Acanthocircus trizonalis s.1. (Rüst)

Saturnulus dizonius Rüst, 1898, p. 8, pl. 2, fig. 3.

Saturnulus trizonalis Rüst, 1898, p. 9, pl. 2, fig. 4; Fischli, 1916, p. 47, fig. 52.

Acanthocircus trizonalis (Rüst)(?) Foreman, 1973, p. 261, pl. 4, figs. 6-8, emend. Foreman, 1975, p. 610, pl. 2D, fig. 3 (only); Foreman, 1978, p. 744 , pl. 1, fig. 9 .

Spongosaturnalis amissus Squinabol, Moore, 1973, p. 824, pl. 3, fig. 2.

Acanthocircus amissus Squinabol, Donofrio and Mostler, 1978, p. 23, pl. 1 , figs. 1,10 , pl. 5 , figs. (?) $1,3,4, ? 6, ? 9$, non fig. 2 ; pl. 6 , figs. $4, ? 6$, non figs. 8,11 .

Acanthocircus trizonalis (Rüst) De Wever and Thiebault, 1981, p. 584, pl. 2, fig. 16 ; Schaaf, 1981 , p. 431 , pl. 16, fig. 1 ; Schaaf, 1984 , p. 155 , fig. 5; Sanfilippo and Riedel, 1985, p. 592, fig. 1c (only); Pavsic and Gorican, 1987, p. 23, pl. 2, fig. 3 .

Acanthocircus sp. Schaaf, 1981, p. 431, pl. 7, fig. 7.

Occurrences. Tethyan, Atlanic, Pacific, Site 765: Table 2.

Range. Published: Valanginian to Aptian.

3087 Acanthocircus trizonalis dicranacanthos (Squinabol) sensu Foreman

Saturnalis dicranacanthos Squinabol, 1914, p. 289, pl. 22, figs. 4-7. pl. 23, fig. 8; text-fig. 1, p. 290.

Saturnalis novalensis Squinabol, 1914, p. 268, 297, pl. 20, fig. 1; pl. 23, fig. 7.

Saturnulus sp. Fischli, 1916, p. 46, fig. 53.

Spongosaturnalis dicranacanthos Squinabol, Pessagno, 1969, p. 610, pl. 4 , figs. A, B; Moore, 1973 , p. 824 , pl. 3, figs. 1,3 .

Acanthocircus dizonius (Rüst)(?) Foreman, 1973, p. 260, pl. 4, figs. 4, 5. Acanthocircus dizonius Rüst, Riedel and Sanfilippo, 1974, p. 775, pl. 2, figs. 4,5 , non fig. 3 .

Acanthocircus dicranacanthos Squinabol, Foreman, 1975, p. 610, pl. 2D figs. 5, 6; Muzavor, 1977, p. 37, pl. 4, fig. 4; Pessagno, 1977a, p. 73 pl. 3, fig. 35; Pessagno, 1977b, p. 31, pl. 2, fig. 6; Donofrio and Mostler, 1978 , p. 28 , pl. 2, fig. 3 ; pl. 4 , figs. 4, 7-9; pl. 5, figs. $10-11$; Nakaseko et al., 1979, p. 2, fig. 7; Baumgartner et al., 1980, p. 49, pl 1, fig. 11; Holzer, 1980 , p. 156, text-fig. 2, pl. 1, figs. 1-12; pl. 2, fig. 7-9; Kanie et al., 1981, pl. 1, fig. 3; Kocher, 1981, p. 51, pl. 12, fig. 3; Nakaseko and Nishimura, 1981, p. 141, pl. 1, fig. 6; Schaaf, 1981, p. 431 , pl. 7, fig. 1 ; pl. 16 , fig. 3 ; Aoki, pl. 1 , fig. 3 ; Baumgartner, 1984b, p. 754, pl. 1, fig. 5; Murchey, 1984, pl. 2, fig. 7; Ozvoldova and Sykora, 1984 , p. 261 , pl. 1, figs. 6, 7; Schaaf, 1984, p. 106-107, figs. 1-5; Sanfilippo and Riedel, 1985, p. 591, pl. 5, FIGS. 2a-2e; Aita and Okada, 1986, p. 108, pl. 1, fig. 5; De Wever et al., 1986, pl. 6, figs. 3-4; Pavsic and Gorican, 1987, p. 22, pl. 2, fig. 2; Ozvoldova and Petercakova, 1987, pl. 31, fig. 3; Ozvoldova, 1988, pl. 3, fig. 7.

Occurrences. Tethyan, Atlantic, Pacific, Site 765: Table 2.

Range. Published: Kimmeridgian to early Barremian.

3228 Alievium helenae Schaaf

Alievium sp. Foreman, 1973, p. 262, pl. 9, figs. 1, 2; Matsuyama et al., 1982, pl. 1, fig. 8; Aita and Okada, 1986, p. 1, fig. 9.

Alievium spp. Foreman, 1975, p. 613, pl. 2D, figs. 7, 8; pl. 5, fig. 14. 
Alievium sp. A Pessagno, 1977a, p. 29, pl. 3, figs. 10, 18; Kanie et al., 1981 , pl. 1, fig. 4 .

Alievium helenae Schaaf, Baumgartner et al., 1980, p. 49, pl. 1, fig. 8; Kocher, 1981, p. 53, pl. 12, fig. 6; Schaaf, 1981, p. 431, pl. 7, fig. 9; pl. 10, figs. 2a, 2b; Aoki, 1982, pl. 2, fig. 3; Baumgartner, 1984b, p. 755 , pl. 1, figs. 8-10; Schaaf, 1984, p. 112, 113, figS. 1-3b; De Wever et al., 1986, pl. 6, fig. 10; Pavsic and Gorican, 1987, p. 23, pl. 2, fig. 9; Kito, 1987, pl. 1, fig. 9; Taketani, 1982, pl. 1, fig. 2.

Occurrences. Tethyan, Atlantic, Pacific. Isolated occurrences at Site 765 , Samples 765C-53R-2, 102-105 cm, to $-43 R-5,47-51 \mathrm{~cm}$.

Range. Published: latest Tithonian to early Aptian.

3605 Genus AMPHIPYNDAX Foreman sensu Empson-Morin

Amphipyndax Foreman, 1966, p. 355; Empson-Morin, 1982, p. 508.

Type species. Amphipyndax enesseffi Foreman, 1966, p. 356, text figs. 10, 11 (junior synonym of Lithostrobus pseudoconulus Pessagno, 1963 , p. 210 , pl. 1, fig. 8 , pl. 5 , figs. 6,8 ).

\section{Amphipyndax mediocris Tan Sin Hok}

Dictyomitra mediocris Tan Sin Hok, 1927, p. 55, pl. 10, fig. 82.

Amphipyndax mediocris Tan Sin Hok, Renz, 1974, p. 788, pl.5, figs. 7-9,

pl. 12, fig. 3; Schaaf, 1981 , p. 431 , pl. 3, fig. 11, pl. 22, figs. 7a, 7b; Thurow, 1988, p. 397 , pl. 1, fig. 7, pl. 4, fig. 5.

Occurrences. Tethyan, Atlantic, Indian Ocean: Site 260, Samples $260-13-1,110-112 \mathrm{~cm}$, to $260-12-1,131-133 \mathrm{~cm}$. Site 261, Samples 261-23-2, 80-82 cm, to 261-9-2, 110-112 CM. Site 765, Sample 123765C-53R-2, 102-105 cm, to $123-765 \mathrm{C}-42 \mathrm{R}-4,148-150 \mathrm{~cm}$.

Range. Indian Ocean: late Hauterivian/early Barremian to Aptian or younger.

\section{Genus ANGULOBRACCHIA Baumgartner}

Angulobracchia sp. Baumgartner, 1980, p. 310.

Type species. Paronaella(?) purisimaensis Pessagno, 1977a.

$$
\begin{aligned}
& 5223 \text { Angulobracchia(?) media Steiger } \\
& \text { (PI. 3, Figs. 4, 5) }
\end{aligned}
$$

Hagiastrids gen. et sp. indet. Foreman, 1973, p. 261, pl. 6, figs. 5, 6.

Angulobracchia media Steiger, 1987, p. 110, pl. 11, figs. 12, 13.

Occurrences. Tethyan, Pacific. Site 765: Table 2.

Range. Site 765: Barremian to early Aptian.

$$
\begin{gathered}
3911 \text { Angulobracchia(?) sp. A } \\
\text { (Pl. 3, Fig. 7) }
\end{gathered}
$$

Angulobracchia(?) portmanni Baumgartner, Steiger, 1987, pl. 12, fig. 8.

Occurrences. Tethyan, Site 765: Table 2.

Range. Site 765: latest Berriasian to early Aptian.

$$
3607 \text { Angulobracchia spp. }
$$

Occurrences. Tethyan. Site 765: Table 2.

\section{Genus ARCHAEODICTYOMITRA Pessagno}

Archaeodictyomitra Pessagno, 1976, p. 49.

Type species. Archaeodictyomitra squinaboli Pessagno, 1976, p. 50, pl. 5 , figs. $2-8$.

\section{Archaeodictyomitra sp. aff. A. apiarium (Rüst)}

$$
\text { (Pl. 3, Fig. 8) }
$$

Description, Remarks. This form differs from A. apiarium (Rüst) sensu Baumgartner, 1984b, p. 758, pl. 2, figs. 5 and 6 by being shorter and having only one terminal constricted segment. However, it is closely related to the latter.

Occurrences. Site 765: Table 2.

Range. Site 765: late Berriasian or earliest Valanginian (LO truncated).
5601 Archaeodictyomitra brouweri s.1. (Tan Sin Hok)

$$
\text { (Pl. 3, Figs. 9, 10) }
$$

Eucyrtidium brouweri Tan Sin Hok, 1927, p. 58.

Description, Remarks. All broadly conical or spindle-shaped forms with continuous longitudinal plicae and one row of pores between plicae are included under this group for counting purposes, where a differentiation into subspecies was impossible. This group also accommodates the forms not assignable to one of the subspecies listed below.

Occurrences. This group is probably indigenous of the eastern Indian Ocean and forms an important fraction of the "clay faunas" and also of some "sand faunas." Site 765: Table 2.

Range. Early Berriasian to early Aptian.

$$
5604 \text { Archaeodictyomitra brouweri alpha (Tan Sin Hok) }
$$$$
\text { (PI. 3, Figs. 14, 15) }
$$

Eucyrtidium brouweri var. alpha Tan Sin Hok, 1927, p. 58, pl. 11, fig. 93; Moore, 1973, pl. 14, figs. 7-9.

Dictyomitra brouweri var. alpha Tan Sin Hok, Renz, 1974, p. 790, pl. 8 , figs. 14-16, pl. 11, fig. 26.

Occurrences. Indian Ocean: Roti, Sites 149, 259, 260, 261, 765: Table 2.

Range. Early Cretaceous (Berriasian-Barremian?).

5605 Archaeodictyomitra brouweri gamma (Tan Sin Hok)

Eucyrtiudium brouweri var. gamma Tan Sin Hok, Tan Sin Hok, 1927, p. 58 , pl. 11, fig. 91.

Dictyomitra brouweri var. gamma Tan Sin Hok Renz, 1974, p. 790, pl. 8 , figs. 9-13, pl. 11, fig. 27.

Occurrences. Indian Ocean: Roti, Sites 149, 259, 261, 765: Table 2. Range. Early Cretaceous (Berriasian-Barremian?).

5606 Archaeodictyomitra brouweri typica (Tan Sin Hok)

$$
\text { (Pl. 3, Fig. 11) }
$$

Eucyrtiudium brouweri typicum (Tan Sin Hok) Tan Sin Hok, 1927, p. 58, pl. 11, fig. 91 .

Description, Remarks. It is not clear whether part or all forms included under this name should be assigned to the genus Thanarla (Thanarla conica (Aliev), sensu Pessagno, 1977?). Tan Sin Hok's illustration clearly shows terminal teeth and thus belongs to the genus $\mathrm{Ar}$ chaeodictyomitra. Some of the included forms exhibit a tendency to have terminal blades rather than teeth. This distinction is, however, very difficult to make in routine incident light microscopy.

Occurrences. Indian Ocean: Roti, Site 765: Table 2.

Range. Early Cretaceous (Berriasian-Barremian?).

\section{Archaeodictyomitra sp. A}

(Pl. 3, Fig. 16)

Description, Remarks. Relatively large, broadly dome-shaped form having large, closely spaced circular pores. This form is related to the $A$. apiarium-A. excellens group. However, no constricted distal portion was observed.

Occurrences. Site 765: Table 2.

Range. Site 765: early Berriasian to early Aptian.

$$
5626 \text { Archaeodictyomitra spp. (slender group) }
$$$$
\text { (PI. 3, Figs. 12, 13, 17-19) }
$$

Description, Remarks. This group includes all slenderly conical archaeodictyomitrids, with or without externally visible strictures and a variable degree of distal constriction. Some of the included forms may be assignable to A. vulgaris Pessagno, 1977 (e.g., Pl. 3, Fig., 18). Because the fine pore structure is often poorly preserved, it remains uncertain whether some of the forms should be assigned to the genera Mita Pessagno or Zifondium Pessagno or to yet undescribed Archaeodictyomitra spp.

Occurrences. Site 765: Table 2. 


\section{Genus CECROPS Pessagno}

Cecrops Pessagno, 1977b, p. 32.

Type species. Staurosphaera septemporata Parona, 1890, p. 151, pl. 2 , figs. 4,5

\section{Cecrops septemporatus (Parona)}

Staurosphaera septemporata Parona, 1890, p. 151, pl. 2, figs. 4, 5; Cita and Pasquare, 1959 , p. 398 , fig. 3, not 7 . Moore, 1973, p. 824, pl. 2, fig. 2;Foreman, 1973, p. 259, pl. 3, fig. 4; Riedel and Sanfilippo, 1974, p. 780 , pl. 1, figs. $6-8$;Foreman, 1975 , p. 609 , pl. 2E, fig. 7, pl. 3, fig. 6: Muzavor, 1977, p. 53, 54, pl. 1, figs. 9, 10; Nakaseko et al., 1979, p. 24, pl. 2, figs. 5, 6; Kanie et al., 1981, pl. 1, fig. 5; Schaaf, 1981, p. 439 , pl. 7 , figs. $8 \mathrm{a}, 8 \mathrm{~b}$, pl. 16, figs. 10a, 10b; Nakaseko and Nishimura, 1981, p. 161, pl. 1, fig. 2; Okamura and Uto, 1982, pl. 7, fig. 19.

Staurolonche robusta Rüst, Fischli, 1916, text-fig. 36.

Staurolonche sp. Fischli, Fischli, 1916, text-fig. 37.

Cecrops septemporatus Parona, Pessagno, 1977b, p. 33, pl. 3, fig. 11; Baumgartner et al., 1980, p. 51, pl. 2, fig. 7; Okamura and Uto, 1982, pl. 7, fig. 19; Baumgartner, 1984b, p. 761, pl. 2, figs. 17, 18; Thurow, 1988, p. 398, pl. 9, fig., 18 .

Cecrops septemporata Parona, Nakagava et al., 1980, pl. 1, figs. 2, 5; Kocher, 1981, p. 59, 60, pl. 12, fig. 25; Tajika and Iwaka 1983, pl. 1, fig. 6.

“Cecrops" septemporatus Parona, Kito, 1987, pl. 1, fig. 1; Igo, 1987, text-fig. 2 , no. 6 .

Occurrences. Tethyan, Atlantic, Pacific. Isolated occurrence at Site 765, Sample 123-765C-53R-2, 102-105 cm.

Range. Published: late early Valanginian to Barremian.

\section{Cenosphaera spp.}

(Pl. 4, Fig. 1)

Description, Remarks. A number of large spherical forms with regular hexagonal pore pattern occurring in almost every sample is included under this name.

Occurrences. Site 765: Table 2.

\section{Genus CRUCELLA Pessagno}

Crucella Pessagno, 1971, p. 52. $1-3$.

Type species. Crucella messinae Pessagno, 1971, p. 56, pl. 6, figs.

\section{Crucella cachensis Pessagno}

(Pl. 4, Figs. 2-3)

Crucella cachensis Pessagno, 1971, p. 53, 54, pl. 9, figs. 1-3; Pessagno, 1976 , p. 31 , 32 , pl. 3 , figs. 14 , 15 ; Taketani, 1982 , p. 50 , pl. 9 , fig. 16 ; Thurow and Kuhnt 1986, text-fig. 9; Thurow, 1988, p. 399, pl. 2, fig. 13.

Occurrences. Tethyan, Atlantic, Site 765: Table 2.

Range. Published: latest Cenomanian - Turonian. Site 765: FO: early Aptian.

\section{Crucella sp. aff. C. espartoensis Pessagno}

$$
\text { (Pl. 4, Fig. 4) }
$$

Spongodiscid 1 gen. and sp. indet. Renz, 1974, p. 796, pl. 3, fig. 9, pl. 10, fig. 4 .

Crucella sp. cf. C. cachensis Pessagno, Schaaf, 1981, p.433, pl. 8, fig. 3.

Occurrences. Pacific, Indian Ocean: Site 260, Samples 260-12-CC to-11-CC; Site 261, Samples 261-18-CC to-10-CC; Site 765: Table 2.

Range. Site 765: late Hauterivian or early Barremian to Aptian, isolated occurrence in the late Berriasian or early Hauterivian.

$$
\begin{aligned}
& 3619 \text { Crucella spp. } \\
& \text { (PI. 4, Figs. 5-8) }
\end{aligned}
$$

Description, Remarks. Includes several forms not assigned to a particular species. Plate 4, Figure 5 is probably synonymous with $\mathrm{Cru}$ cella espartoensis Pessagno, 1971, in Renz, 1974, p.790, pl. 1, figs. 11, 12, pl. 9, fig. 4.

Occurrences. Mostly Tethyan forms, Site 765: Table 2.

\section{Genus CRYPTAMPHORELLA Dumitrica}

Cryptamphorella Dumitrica, 1970, p. 80.

Type species. Hemicryptocapsa conara Foreman, 1968, p. 35, pl. 4, figs. 11a, 11b.

\section{Cryptamphorella sp. aff. C. macropora Dumitrica}

$$
\text { (Pl. 4, Figs. 12-14) }
$$

aff. Cryptamphorella macropora Dumitrica, 1970, p. 81, pl. 11, figs. 67, 71, 72; pl. 20, fig. 132; pl. 21, figs. 140, 141; not: figs. 64, 65, 69.

Description, Remarks. This form differs from Cryptamphorella macropora by having a larger, more protruding cephalothorax, but is otherwise very similar.

Occurrences. This form is probably indigenous to the eastern Indian Ocean and is present in the "clay faunas" and also in some "sand faunas," Site 765: Table 2.

Range. Late Berriasian to early Valanginian.

$$
6143 \text { Cryptamphorella sp. A }
$$$$
\text { (Pl. 4, Figs. 10, 11, and 15) }
$$

Description, Remarks. Spherical form with cephalothorax almost completely depressed in abdominal wall. A flat area without pores marks the area of cephalothorax. A large, depressed sutural pore is present next to that area.

Occurrences. This form is probably indigenous of the eastern Indian Ocean and forms an important fraction of the "clay faunas" and also of the "background" of some "sand faunas." Site 765: Table 2.

Range. Early Cretaceous (Berriasian to Valanginian?).

\section{Cryptamphorella spp.}

Description, Remarks. Includes all undifferentiated forms assignable to this genus.

Occurrences. Some forms belonging to this group are probably indigenous to the eastern Indian Ocean and occur in the "clay faunas" and also in the "background" of some "sand faunas." Site 765: Table 2.

\section{Cryptocephalic and cryptothoracic nassellarians}

Description, Remarks. Includes all undifferentiated cryptocephalic and cryptothoracic nassellarians, occurring abundantly as small spherical forms in most samples.

\section{Genus CYCLASTRUM Rüst}

Cyclastrum Rüst, 1898, p. 28.

Type species. Cyclastrum infundibuliforme Rüst, 1898, p. 28, pl. 9, fig. 5 .

\section{Cyclastrum infundibuliforme Rüst}

(Pl. 5, Figs. 1, 6)

Cyclastrum infundibuliforme Rüst, 1898, p. 28, pl. 9, fig. 5; Schaaf, 1981, p. 433, pl. 14, fig. 8; Thurow, 1988, p. 400, pl. 9, fig. 21 .

Occurrences. Tethyan, Atlantic, Pacific, Site 765: Table 2.

Range. Published: late Barremian. Site 765: late Hauterivian or early Barremian to early Aptian.

\section{Cyclastrum sp. A \\ (P1. 5, Fig. 2)}

Cyclastrum sp. B Holzer, 1980, pl. 2, fig. 5 only.

Description, Remarks. Form with three rays embedded in a central spongy meshwork and extending into three primary spines. Several secondary spines may fringe the spongy ring.

Occurrences. Tethyan. Site 765: Table 2.

Range. Barremian(?).

$$
3622 \text { Genus Cyrtocapsa Haeckel }
$$

Cyrtocapsa Haeckel, 1881, p. 439. 11.

Type species. Cyrtocapsa ovalis Rüst, 1885, p. 320, pl. 42 (17), fig. 
5506 Cyrtocapsa grutterinki Tan Sin Hok

Cyrtocapsa grutterinki var. alpha Tan Sin Hok, 1927, p. 65, pl. 13, fig. 111; Renz, 1974, p. 790 , pl. 6, figs. 1-3, pl. 11, fig. 7 .

Occurrences. Tethyan, Indian Ocean: Roti, Sites 259, 260, 261. Site 765 , Sample 123-765C-42R-4, 148-150 cm.

Range. Aptian (and younger?).

\section{Cyrtocapsa(?) sp. aff. C. pseudacerra Tan Sin Hok \\ (PI. 5, Figs. 3, 4, 7, 8)}

Cyrtocapsa preudacerra Tan Sin Hok, p. 68, pl. 14, fig. 123.

Description, Remarks. Smooth, elongate, egg-shaped form having a conical proximal and rounded or flat distal part. Cephalis sometimes bears a small horn. Number of segments probably 8 to 9 , inner structure not known. Cephalis and thorax smooth, sparsely porous. Remaining segments have irregular meshwork of circular and elliptic pores, suggesting a "spongy" meshwork. Some forms show raised ridges between pores. This form differs from Tan Sin Hok's species by having pores arranged more irregularly and by having an apparently thicker wall.

Occurrences. This species is either indigenous to the eastern Indian Ocean or initially immigrated from southern high latitudes and occurs rarely in "clay faunas" and in the "sand faunas" of Site 765, Cores 62R-57R; see Table 2.

Range. Tithonian? or Berriasian to Valanginian.

$$
\begin{gathered}
5612 \text { Cyrtocapsa(?) sp. A } \\
\text { (P1. 5, Figs. 5, 9-14) }
\end{gathered}
$$

Description, Remarks. Medium-sized form without strictures. Proximal portion conical distal porting cylindical second-last segment bowlshaped, delicate last segment much smaller than second last, rounded, rarely preserved. Cephalis smooth, round or with small point, sparsely porous. Thorax and following seven to eight segments have irregular polygonal pore frames composed of raised ridges surrounding small circular or polygonal pores forming an inner "spongy" wall layer. Details of inner structures unknown.

Occurrences. This species is either indigenous to the eastern Indian Ocean or initially immigrated from southern high latitudes and occurs rarely in "clay faunas" and in the "sand faunas" of Site 765 , Cores 62R-57R, see Table 2.

Range. Tithonian or older to Valanginian.

\section{Genus EUCYRTIS Haeckel}

Eucyrtis Haeckel, 1881, p. 438; Haeckel, 1887, p. 1488.

Type species. Eucyrtis conoidea Rüst, 1885, p. 316, pl. 40, fig. 10.

\section{Eucyrtis columbaria Renz}

$$
\text { (Pl. 6, Figs. 1-3) }
$$

Eucyrtis columbaria Renz, 1974, p. 792, pl.7, figs. 14-20, pl. 12, figs. 13a-c13; Foreman, 1975, p. 615, pl. 2I, fig. 19; Schaaf, 1981, p. 434, pl. 5, figs. 1a, 1b, pl. 27. figs. 2a, 2b, 3a-b; Schaaf, 1984, p. 100, 101.

Occurrences. Tethyan, Atlantic, Pacific, Indian Ocean: Sites 259, 260, 261, Site 765: Table 2.

Range. Published: late Valanginian to early Aptian, Indian Ocean: early Barremian to Aptian.

\section{Eucyrtis hanni (Tan Sin Hok)}

(Pl. 6, Fig. 4)

Lithocampe hanni Tan Sin Hok, 1927, p. 64, pl. 13, fig. 109; Renz, 1974, p. 792 , pl. 7 , figs. $21-25$, pl. 12 , fig. 16 ; Schaaf, 1984 , p. 157 , fig. 8 . Eucyrtis hanni Tan Sin Hok, Riedel and Sanfilippo, 1974, p. 779, pl. 5, figs. 9-13, pl. 12, figs. 16-18.

Occurrences. Tethyan, Pacific, Indian Ocean. Site 765: Table 2. Range. Published: early Valanginian to middle Aptian, Indian Ocean: Barremian-Aptian.

5611 Eucyrtis micropora (Squinabol) sensu Sanfilippo and Riedel

$$
\text { (P1. 6, Fig. 5) }
$$

Archicapsa micropora Squinabol, 1903, p. 129, pl. 9, fig. 14.

Eucyrtis micropora Squinabol, Foreman, 1975, p. 615, pl. 21, figs. 2, 4; Sanfilippo and Riedel, 1985 , p. 619, fig. 13.6.
Occurrences. Tethyan, Atlantic, Pacific, Indian Ocean, Site 765 : Table 2.

Range. Published: Berriasian to late Aptian.

$$
5610 \text { Eucyrtis tenuis (Rüst) sensu Sanfilippo and Riedel }
$$

$$
\text { (P1. 6, Fig. 6) }
$$

Stichocapsa tenuis Rüst, 1885, p. 318, pl. 41, figs. 13, 14.

Eucyrtis tenuis Rüst, Foreman, 1975, p. 615, pl. 21, fig. 9; Sanfilippo and Riedel, 1985 , p. 619 , fig. 13.5 .

Occurrences. Pacific, Indian Ocean: Site 765: Table 2.

Range. Published: Hauterrivian to Aptian. Site 765: FO: Barremian.

\section{Genus EUSYRINGIUM Haeckel}

Eusyringium Haeckel, 1887, p. 1468.

\section{Eusyringium sp. A \\ (Pl. 6, Figs. 7-9)}

Description, Remarks. Conical form without strictures, last segment tapers into a thin, closed tube. Cephalis poreless, conical. Thorax trapezoidal, with one row of pores at base. Abdomen and remaining four to five segments cylindrical, slightly inflated, gradually gaining width. Last and widest segment hemispherical or inverted conical, tapering distally into a thin, short, terminal tube. Surface of post-abdominal segments covered with a uniform polygonal meshwork around small circular or elliptic pores.

Occurrences. This form is known from the "sand faunas" of Site 765, Cores 765C-62R to 765C-51R (Table 2). Probably "circumantarctic" (see text).

Range. Tithonian or older to Barremian.

\section{Eusyringium sp. B \\ (Pl, 6, Figs. 10-13)}

Description, Remarks. Conical form having strictures at segmental divisions; last segment tapers into a thin, closed tube. Cephalis with one pore, conical with a blunt tip. Thorax trapezoidal, with one row of pores at base. Abdomen and remaining four or five segments cylindrical, slightly inflated and gradually gaining width. Last segment as wide or narrower than second last; hemispherical or inverted conical tapering distally into a thin, short, terminal tube. Post-abdominal segments show irregular polygonal pore frames; sometimes having raised transverse ridges or nodes marking the segmental bulge or sometimes vertically elongated pore frames marking the segmental stricture.

Occurrences. This form is known only from the "sand faunas" of Site 765 , Cores $123-765 \mathrm{C}-59 \mathrm{R}$ to $-55 \mathrm{R}$ (Table 2). Its occurrence shows an acme in Cores 123-765C-59R to -58R (see Fig. 3). Probably "circumantarctic" (see text).

Range. Late Berriasian or earliest Valanginian to Hauterivian.

$$
\begin{gathered}
\text { 6123 Eusyringium sp. C } \\
\text { (P1. 6, Figs. 14-16, 22-23) }
\end{gathered}
$$

Description, Remarks. Slender spindle-shaped form with well-defined segmental divisions creating a lobate outline. Last segment tapers into a thick, fragile tube. Cephalis and thorax (and abdomen?) forming together a smooth, poreless conical portion with a well-developed horn. Post-abdominal segments tire-shaped, nearly constant in height and gradually increasing in width. Second last or last segment is widest. Post-abdominal segments show hexagonal or more irregular polygonal pore frames. This species is ancestor to 5619 Eusyringium sp. D. It differs from the latter by having a smooth surface of the test without raised nodes and bars on pore frames. Transitional forms exist.

Occurrences. This form is known only from the "sand faunas" of Site 765 , Cores 123-765C-54R to -52R (Table 2). Its occurrence shows an acme in Core 123-765C-53R (see Fig. 3). Probably "circumantarctic" (see text).

Range. Late Hauterivian to early Barremian.

$$
\begin{aligned}
& \text { 5619 Eusyringium sp. D } \\
& \text { (P1. 6, Figs. 17-20) }
\end{aligned}
$$

Description, Remarks. Conical form with long horn and distinct transverse ridges on proximal part, formed by raised bars. Cephalis and thorax forming together a smooth, poreless, conical portion with a long 
horn. Post-abdominal segments tire-shaped, nearly constant in height and gradually increasing in width. Third last or second last segment is widest. Last segment is fragile, tapering into a thin horn, where preserved. Post-abdominal segments show hexagonal or more irregular polygonal pore frames with raised bars and thorny nodes at intersection of bars. This species descended from 5623 Eusyringium $\mathrm{sp}$. C. It differs from the latter by having a rough surface of the test with raised nodes and bars on pore frames, resulting in transverse ridges and a thorny outline of test. Transitional forms occur.

Occurrences. This form is known only from the "sand faunas" of Site 765 , Cores 123-765C-53R to 43R (Table 2) and from Site 766, Core 26R. Its occurrence shows an acme in Cores 123-765C-53R to -51R (see Fig. 3). Probably "circumantarctic" (see text).

Range. Late Hauterivian or early Barremian to Aptian.

\section{Genus FOREMANELLA Muzavor}

Foremanella Muzavor, 1977, p. 67; Sanfilippo and Riedel, 1985, p. 593.

Type species. Foremanella alpina Muzavor, 1977, p. 67, pl. 3, fig. 4.

\section{Foremanella diamphidia diamphidia (Foreman)}

(Pl. 7, Fig. 1)

Paronaella (?)diamphidia Foreman, 1973, p. 262, pl. 8, figs. 3, 4; Riedel and Sanfilippo, 1974, pl. 12, fig. 4; Foreman, 1975, p. 612, pl. 5, figs. 4, 5; Foreman, 1978, p. 744, pl. 1, figs. 5, 6; Baumgartner et al., 1980 , p. 302 , pl. 4, fig. 4; Schaaf, 1981, p. 436, pl. 13, fig. 4

Foremanella diamphidia Foreman, Baumgartner, 1984b, p. 765, pl. 6, fig., 18; Matsuoka and Yao, 1985, pl. 2, fig. 9; Sanfilippo and Riedel, 1985, p. 593, figS. 5.4a, 5.4b; Aita and Okada, p. 112, pl. 1, fig. 10; Aita, 1987, p. 63, pl. 8, fig. 11; Kito, 1987, pl. 1, fig. 5; Pavsic and Gorican, 1987, p. 436, pl. 13, fig. 4.

Paronaella(?) sp. Yao, 1984, pl. 3, fig. 25.

Occurrences. Tethyan. Indian Ocean: Site 765: Table 2.

Range. Published: late Jurassic to mid-Aptian.

3111 Foremanella diamphidia hipposidericus (Foreman) (Pl. 7, Fig. 5)

Paronaella(?) hipposidericus Foreman, 1975, p. 612, pl. 2E, figs. 1, 2; pl. 5, figs. 3, 7, 10; Baumgartner, 1980, p. 302, pl. 4, figs. 1-3; Baumgartner et al., 1980, pl. 2, fig. 4.

Foremanella hipposidericus (Foreman) Baumgartner, 1984b, p. 765, pl. 6, fig. 19; Riedel and Sanfilippo, 1985, p. 593, fig. 5.3; Aita, 1987, p. 63, pl. 12, fig. 8; Ozvoldova and Petercakova, 1987, pl. 34, figs. 2, 3. Occurrences. Tethyan. Indian Ocean: Site 765: Table 2. Range. Published: Late Jurassic to mid-Aptian.

\section{Genus HISTIASTRUM Ehrenberg}

Histiastrum Ehrenberg, 1847, p. 54; Haeckel, 1881, p. 460; Haeckel, 1887, p. 544.

Type species. Histiastrum quarternarium Ehrenberg, 1875, p. 74, pl. 24 , figs. 3,4 .

\section{Histiastrum cruciferum Lipman}

(Pl. 7, Figs. 2, 3)

Histiastrum cruciferum Lipman, 1952, pl. 2, fig. 5.

Occurrences. Tethyan. Indian Ocean: Site 765: Table 2.

Range. Site 765: early Barremian to Aptian.

\section{Genus HOLOCRYPTOCANIUM Dumitrica}

Holocryptocanium Dumitrica, 1970, p. 75;

Type species. Holocryptocanium tuberculatum Dumitrica, 1970, p. 75 , pl. 16, figs. 102, 103a-103c, pl. 21, figs. 138a, 138 b.

\section{Holocryptocanium barbui barbui Dumitrica} (PI. 7, Fig. 4)

Holocryptocanium barbui Dumitrica, 1970 , p. 76,77 , pl. 17,figs. 105108, pl. 21, fig. 136; Schaaf, 1981, p. 435, pl. 2, fig. 1, pl. 10, fig. 6; Baumgartner, 1984b, p. 768 , pl. 4, fig. 14; Yao, 1984, pl. 5, fig. 1; Okamura and Matsugi 1986, pl. 3, fig. 3; Igo et al., 1987, text-fig. 2, no., 18; Kito, 1987, pl. 2, fig. 11; Vishnevskaya, 1988, pl. 11, figs. 1-3; Kato and Iwata, 1989, pl. 4, fig. 10.

Holocryptocanium japonicum Nakaseko and Nishimura, Nakaseko et al., 1979, p. 23, pl. 5, figs. 8, 10; Okamura, 1980, pl. 21, fig. 5; Taketani, 1982 , p. 67 , pl. 13, fig. 21.

Holocryptocanium barbui japonicum Nakaseko and Nishimura, 1981, p. 154, pl. 3, figs. 5-7; Suyari and Kuwano, 1986, pl. 3, fig. 4; Suyari, 1986, pl. 9, fig. 9.

Holocryptocanium sp.(?) Schaaf, 1981, pl. 2, fig. 8; Okamura and Uto, 1982, pl. 4, figs. 3, 4; Suyari, 1986, pl. 5, fig. 7; Suyari, 1986, pl. 4, fig. 9 .

Occurrences. Tethyan. Indian Ocean: Site 765: Table 2. Seems to be autochthonous to the Argo Basin, becauses not found in the Weddell Sea (Ling and Lazarus, 1990).

Range. Published: late Berriasian to Albian/Cenomanian. Site 765: If Core $765 \mathrm{C}-62 \mathrm{R}$ is older than Berriasian, as suggested by Kaminsiki et al. (this volume), this species may range down to the Tithonian at Site 765.

\section{Genus LITHATRACTUS}

\section{Lithatractus pusillus (Campbell and Clark)}

Stylosphaera (Stylosphaerella) pusilla Campbell and Clark, 1944, p. 5, pl. 1, figs. 2, 4, 5 .

Sphaerostylus (Sphaerostylantha) hastatus Campbell and Clark, 1944, p. 5, pl. 1. figs. 1,6 .

Stylosphaera pusilla Campbell and Clark, Renz, 1974, p. 798, pl. 9, fig. 20, not: pl. 2, figs. 17,18 .

Ellipsoxiphus pusilla Campbell, Foreman, 1978, p.742, 743, pl. 2, figs. $9,10,17$.

Praestylosphaera hastata Campbell and Clark, Empson-Morin, 1981, p. 261,262 , pl. 4 , figs. $4,5 a-5 c$.

Lithatractus pusillus Campbell and Clark, Taketani, 1982, p. 48, pl. 1, figs. 8a, 8b, pl. 9, fig. 5; Iwata and Tajika, 1989, pl. 3, fig. 3.

Occurrences. Tethyan. Site 765, Samples 123-765C-52R-3, 57-63 $\mathrm{cm}$, to $-52 \mathrm{R}-2,68-71 \mathrm{~cm}$.

Range. Site 765: early Barremian.

3658 Genus MIRIFUSUS Pessagno sensu Baumgartner

Mirifusus Pessagno, 1977a, p. 83; Baumgartner, 1984b, p. 769.

Type species. Mirifusus guadalupensis Pessagno, 1977a.

\section{Mirifusus chenodes (Renz)}

(Pl. 7, Figs. 6, 7)

Lithocampe chenodes Renz, 1974, p. 793, pl. 7, fig. 30; pl. 12, figs. 14a-14d; Riedel and Sanfilippo, 1974, p. 779, pl. 6, figs. 5-7; pl. 13, fig. 1; Schaaf, 1981, p. 435, pl. 5, fig. 2, pl. 25, figs. 5a-b5, 7; Kocher, 1981, p. 74 , pl. 74, pl. 14, fig. 17; Aita and Okada, 1986, pl. 2, fig. 12; Kato and Iwata, 1989, pl. 1, fig. 3.

Mirifusus chenodes Renz, Baumgartner, 1984b, p. 770, pl. 5, figs. 9, 15; Schaaf, 1984, pp. 98-99, figs. 1, 2, 3a-3b, 4a-4b; (?)De Wever and Miconnet, 1984, p. 387, pl. 5, figs. 1, 2; De Wever et al., 1986, pl. 9, fig. 8; Pavsic and Gorican, 1987, p. 25, pl. 4, fig. 6; Ozvoldova, 1988, pl. 6 , fig. 6 .

Occurrences. Tethyan. Indian Ocean: Site 765: Table 2.

Range. Published: late Jurassic to Barremian. Site 765: Aptian.

\section{Genus NAPORA Pessagno}

Napora Pessagno, 1977a, p. 94.

Type species. Napora bukryi Pessagno, 1977a.

$$
3661 \text { Napora spp. }
$$

Description, Remarks. This group includes all Napora sp. Further studies will be necessary to establish the systematics of this group.

Occurrences. Tethyan, Indian Ocean: Site 765: Table 2.

\section{Genus OBESACAPSULA Pessagno}

Obesacapsula Pessagno, 1977a, p. 87.

Type species. Obesacapsula morroensis Pessagno, 1977a, p. 87, pl. 11, figs. 5-8. 
3202 Obesacapsula verbana (Parona) (Pl. 7, Fig. 8)

Stichocapsa verbana Parona, 1890, p. 171-172, pl. 6, fig. 14; Rüst, 1898, p. 66 , pl. 19 , fig. 7.

Stichocapsa rotunda Hinde, 1900, p. 41, pl. 3, fig. 24; Muzavor, 1977, p. 122 , pl. 5, figs. 11,12 ; Ozvoldova, 1979 , p. 257 , pl. 5, figs. 5, 6; De Wever et al., 1986, pl. 10, fig. 21.

Stichocapsa(?) rotunda Hinde, Foreman, 1973, p. 265, pl.11, figs. 1, 2; pl. 16, fig. 20; Foreman, 1975, p. 616, pl. 2J, fig. 6, pl. 7, fig. 5;

Obesacapsula rotunda Hinde, Pessagno, 1977b, p. 53, pl. 9, figs. 12, 18 (only); Nakaseko et al., 1979, pl. 2, figs. $11 \mathrm{a}, 11 \mathrm{~b}$; Nakaseko and Nishimura, 1981, p. 156, pl. 11, fig. 12; Baumgartner, 1984b, p. 775, pl. 6, fig. 13; Pessagno et al., 1984, p. 29, pl. 4, figs. 8, 10; De Wever and Miconnet, 1984, p. 388; Aita and Okada, 1986, p. 112, pl. 2, figs. 8,9 ; Pavsic and Gorican, 1987 , p. 26 , pl. 4 , fig. 7

Syringocapsa rotunda Hinde, Foreman, 1978, p. 749, pl. 2, fig. 2; Baumgartner et al., 1980, p. 62, pl. 3, fig. 12; Kocher, 1981, p. 97, pl. 16, fig. 30; Ozvoldova and Sykora, 1984, p. 271, pl. 12, fig. 7; pl. 14, figs 4, 6; Schaaf, 1984, p. 152, fig. 15.

Obesacapsula morroensis Pessagno, 1977 a, p. 87 , pl. 11, figs. 5-8; Pessagno et al., 1984, p. 29, pl. 4, fig. 5; Schaaf, 1984, p. 126, 127 , figs. 1-5b; p. 153, fig. 12; Ozvoldova and Petercakova, 1987, pl. 33, figs. 6, 7; Ozvoldova, 1988, pl. 4, figs. 9, 11.

Occurrences. Tethyan. Indian Ocean: Site 765: Table 2

Range. Published: late Tithonian to late Hauterrivian. Site 765: late Berriasian/early Valangianian only.

\section{Genus ORBICULIFORMA Pessagno}

Orbiculiforma Pessagno, 1973, p. 71.

Type species. Orbiculiforma quadrata Pessagno, 1973, p. 73, pl. 16, figs. $1-4$; pl. 18 , fig. 3 .

\section{Orbiculiforma railensis Pessagno}

$$
\text { (Pl. 7, Figs. 9, 10) }
$$

Orbiculiforma railensis Pessagno, 1977b, p. 28 , pl. 1, figs. 14, pl. 12, fig. 5 , not: pl. 1, fig. 21; Thurow, 1988, p. 403, pl. 5, fig., 18, pl. 9, fig. 20.

Occurrences. Tethyan, Indian Ocean: Site 765: Table 2.

Range. Published: Albian. Site 765: Barremian to early Aptian.

\section{Orbiculiforma spp.}

(Pl. 7, Figs. 11, 12)

Description, Remarks. Includes all disc-shaped spongy spummellarians with a central depression and an annular rim.

Occurrences. Tethyan, Indian Ocean: Site 765: Table 2.

\section{Genus PANTANELLIUM Pessagno}

Pantanellium Pessagno, 1977A, p. 78.

Type species. Pantanellium riedeli Pessagno, 1977a.

5065 Pantanellium squinaboli cantuchapai Pessagno and MacLeod (Pl. 8, Fig. 1)

Pantanellium cantuchapai Pessagno and MacLeod, Pessagno et al., 1987, p. 20 , pl. 1 , figs. $9,13-15,22$, pl. 7 , fig. 2 .

Sphaerostylus lanceola Parona, Muzavor, 1977, p. 50, pl. 1, fig. 7, not: fig. 6.

Description, Remarks. Under this name we include all Pantanellium that have distinct nodes on the vertices of pore frames. Usually these forms are smaller and have more pores than Pantanellium squinaboli squinaboli.

Occurrences. Tethyan, Indian Ocean: Site 765: Table 2.

Range. Site 765: Berriasian to Aptian.

5607 Pantanellium squinaboli squinaboli (Tan Sin Hok)

(P1. 8, Figs. 2, 3)

Staurosphaera squinaboli Tan Sin Hok, 1927, p. 35, pl. 6, figs. 9a-9d.

Sphaerostylus lanceola Parona, Foreman, 1973, p. 258, pl. 1, figs. 7-11;

Kanie et al., 1981, pl. 1, fig. 6; Yao, 1984, pl. 4, fig. 19; Aita and Okada, 1986, p. 120, pl. 1, figs. 2, 3; Kato and Iwata, 1989, pl. 1, fig. 10; Iwata and Tajika, 1989, pl. 4, fig. 7.
Pantanellium corriganensis Pessagno, 1977b, p. 33, pl. 3, figs. 5, 6; De Wever et al., 1986, pl. 6, fig. 1.

Pantanellium squinaboli Tan Sin Hok, Nakaseko and Nishimura, 1981, p. 156, pl. 1, figs. 1, 10; Mizutani et al., 1982, p. 64, pl. 5, fig. 7; Ozvoldova and Sykora, 1984, p. 267, pl. 6, fig. 1.

Pantanellium lanceola Parona gr., De Wever and Thiebault, 1981, p. 589. pl. 2, fig. 9 ; Schaaf, 1981 , pl. 7, fig. 6; pl. 16, figs. 5a-5b; Schaaf, 1984 , p. $114-115$, figs. $1-6$, p. 153 , figs. 13 , 14; De Wever et al., 1986, pl. 6, fig. 2; Pavsic and Gorican, 1987, p. 26, pl. 4, figs. 1, 2; Ozvoldova and Petercakova, 1987, pl. 34, fig. 1; Ozvoldova, 1988, pl. 3 , fig. 5 ; not pl. 1 , fig. 4 .

Pantanellium portovenerensis Ciarapica and Zaninetti, 1982, p. 169, 170 , pl. 1 , figs. $1-8$.

Pantanellium sp. Kito, 1987, pl. 1, fig. 4.

Description, Remarks. Under this name we include all Pantanellium without nodes on the vertices of pore frames. These forms are larger than $P$. riedeli and have fewer pores than other Pantanellium.

Occurrences. Tethyan, Roti, Indian Ocean: Site 765: Table 2.

Range. Site 765: Berriasian to early Aptian.

3671 Genus PARONAELLA Pessagno sensu Baumgartner

Paronaella Pessagno, 1971; Baumgartner, 1984b, p. 777.

Type species. Paronaella solanoensis Pessagno, 1971.

5186 Paronaella(?) sp. A.

(PI. 8, Fig. 4)

Description, Remarks. Distinctive form with raised ridges in the central area.

Occurrences. Tethya, Indian Ocean: Site 765: Table 2.

Range. Site 765: late Berriasian/early Valanginian.

\section{Paronaella spp.}

(Pl. 8, Fig. 5)

Description, Remarks. Includes all forms assignable to this genus. Occurrences. Tethyan. Indian Ocean: Site 765: Table 2.

3672 Genus PARVICINGULA Pessagno sensu Baumgartner

Parvigingula Pessagno, 1977a, p. 84; Baumgartner, 1984b, p. 778.

Type species. Parvicingula santabarbarensis Pessagno, p. 86, pl. 9, figs. 11-13.

Remarks. In contrast to Pessagno and Whalen's (1982) emended definition, I include forms with or without apical horn. Most of the forms treated here bear an apical horn.

\section{Parvicingula (?) malleola (Aliev)}

(P1. 8, Fig. 6)

Dictyomitra malleola Aliev, 1961, p. 62, pl. 2, figs. 5-7; Aliev, 1965, p. 48 , pl. 8 , figs. $4-6$; Renz, 1974 , p. 790 , pl. 8 , fig. 20 , pl. 11 , fig. 28 ; Schaaf, 1981 , p. 436 , pl. 21 , figs. $2,12$.

Occurrences. Pacific, Indian Ocean. Site 765: Table 2.

Range. Site 765: early Aptian.

\section{Parvicingula sphaerica Steiger}

Parvicingula sphaerica Steiger, 1987, p. 207, pl. 24, figs. 1, 2.

Parvicingula boesii Parona, Steiger, 1987, p. 205, pl. 23, fig. 6.

Occurrences. Tethyan. Isolated occurrence at Site 765, Sample 123765C-58R-5, 143-145 cm.

Range. Published: Berriasian.

\section{Parvicingula sp. A}

$$
\text { (P1. 9, Figs. 1-4) }
$$

Description, Remarks. Slender, conical form. Cephalis sparsely porous, bearing atapered horn. Cephalis and thorax forming together an inflated conical or dome-shaped portion with irregular or roughly transverse rows of pores. First circumferential ridge at base of thorax. Remaining segments of about same height and only gradually changing width. Seven to nine post-abdominal segments have been preserved, of which the last two may narrow slightly. Pores on post-abdominal segments as with genus, with three transverse rows of pores in hexagonal arrangement. 
Transverse ridges thin, consist of raised pore frames, often bearing sharp edges or spines resulting in a sharp silhouette. Related forms are $P$. burnsensis Pessagno and Whalen, 1982 and $P$. schoolhousensis Pessagno and Whalen, 1982, described from the Middle Jurassic of the Blue Mountains (Oregon).

Occurrences. This form is known only from the "sand faunas" of Site 765, Cores $123-765 C-59 R$ to $-57 R$ (Table 2). Its occurrence shows an acme in Core 123-765c-58R (see Fig. 3). Probably "circumantarctic" (see text).

Range. Late Berriasian or earliest Valanginian to Valanginian.

5608 Parvicingula sp. B

(Pl. 9, Figs. 9-13, 16-17)

Description, Remarks. Spindle-shaped form. Cephalis sparsely porous, round or bearing a tiny horn. Cephalis and thorax (and sometimes abdomen) forming together a broadly conical portion with several, roughly transverse rows of pores. First circumferential ridge at base of thorax or abdomen. Remaining segments of about same height and only gradually increasing in width. Eight to 10 post-abdominal segments occur, of which the last three to four narrow considerably. Pores on post-abdominal segments as with genus, with three transverse rows of pores in hexagonal arrangement. Transverse ridges well-developed, raised pore frames on both sides of ridges give it a stout, rounded silhouette.

Occurrences. This form is known only from the "sand faunas" of Site 765, Cores 123-765C-59R to -53R (Table 2) and from Site 766, Cores 123-766c-49R to -25R. Its occurrence shows an acme in Cores 123-765C58R to -57R (see Fig. 3). Probably "circumantarctic" (see text).

Range. Late Berriasian or earliest Valanginian to late Hauterivian or early Barremian.

\section{Parvicingula sp. C}

$$
\text { (Pl. 9, Figs. 5-7) }
$$

Description, Remarks. Small, spindle-shaped form. Cephalis sparsely porous, bearing a distinct tapered horn. Cephalis thorax and abdomen forming together a dome-shaped portion, with irregular or roughly transverse rows of pores. First circumferential ridge at base of abdomen. Remaining segments of about same height and only gradually changing width. Seven to nine post-abdominal segments have been preserved, of which the last four or five are narrow. Pores on post-abdominal segments as with genus, with three transverse rows of pores in hexagonal arrangement.

Occurrences. This form is known only from the "sand faunas" of Site 765, Cores (Table 2). Probably "circumantarctic" (see text).

Range. Late Berriasian to early Valanginian.

\section{Parvicingula sp. D}

$$
\text { (P1. 9, Figs., 18-20) }
$$

Description, Remarks. Large cylindrical form with conical proximal portion. Cephalis sparsely porous, round or bearing a tiny horn. Cephalis and thorax and abdomen forming together a broadly conical portion with several, roughly transverse rows of pores. First clear circumferential ridge at base of abdomen. Remaining post-abdominal segments of about same height and increasing in width to the first to third post-abdominal segment to form the conical proximal portion. Succeeding four to five segments are sligthly narrower and form a weak constriction of the test. The following segments gradually widen until the last two or three, which narrow considerably. Total of post-abdominal segments is 11 to 14. Pores on post-abdominal segments as with genus, with three transverse rows of pores in hexagonal arrangement. Transverse ridges well developed, raised pore frames on both sides of ridges give it a stout, rounded silhouette.

Occurrences. This form is known only from the "sand faunas" of Site 765, Cores $123-765 C-58 R$ to $-54 R$ (Table 2) and from Site 766, Core 49R. Its occurrence makes an acme in Core 123-765C-57R (see Fig. 3), which can be correlated with the assemblages of Site 766, Core 49R. Probably "circumantarctic" (see text).

Range. Late Berriasian or earliest Valanginian to late Hauterivian or early Barremian.

$$
5609 \text { Parvicingula sp. E }
$$$$
\text { (Pl. 9, Figs. 14, 15) }
$$

Description, Remarks. Long, spindle-shaped form with porous terminal tube. Cephalis sparsely porous, bearing a tapered horn. Cephalis and thorax forming together an inflated conical or dome-shaped portion, with irregular or roughly transverse rows of pores. First circumferential ridge at base of thorax or abdomen. Remaining segments of about same height and only gradually changing width. There are 11 to 14 post-abdominal segments, of which the last four to six gradually narrow, and the last one is a tapering porous tube. Pores on post-abdominal segments as with genus, with three transverse rows of pores in hexagonal arrangement. Transverse ridges well developed, rounded, without spines or nodes.

Occurrences. This form is known only from the "sand faunas" of Site 765 cores (Table 2). Probably "circumantarctic" (see text).

Range. Berriasian to late Haurerrivian/early Barremian.

$$
\begin{aligned}
& 5635 \text { Parvicingula sp. F } \\
& \text { (Pl. 9, Fig. 8) }
\end{aligned}
$$

Description, Remarks. Small, symmetrically spindle-shaped form with about 10 segments. Cephalis without horn forming together with thorax and abdomen a smooth, porous, conical proximal portion. Remaining post-abdominal segments have stout transverse ridges at segmental divisions, formed by coarse raised pore frames. Last four segments gradually decreasing in width but constant in height. Last segments cup-shaped, porous, without aperture.

Occurrences. This form is known only from the "sand faunas" of Site 765 (Table 2). Probably "circumantarctic" (see text). Site 765, Samples 123-765C-59R-2, 96-98 cm, to -56R-2, 18-20 cm.

Range. Late Berriasian to late Hauterivian/early Barremian.

$$
6127 \text { Parvicingulid sp. A }
$$$$
\text { (Pl. 8, Figs. 7, 8) }
$$

Occurrences. This form is known only from the "sand faunas" of Site 765 , Cores 52R to 42R (Table 2). Probably "circumantarctic" (see text). Range. Barremian to early Aptian.

$$
\begin{aligned}
& 6125 \text { Parvicingulid sp. B } \\
& \text { (P1. 8, Fig. 12) }
\end{aligned}
$$

Occurrences. This form is known only from the "sand faunas" of Site 765 , Cores 51R to 42R (Table 2). Probably "circumantarctic" (see text). Range. Barremian to early Aptian.

\section{Parvicingulid sp. C (Pl. 8, Figs. 13-17)}

Remarks. A similar form was recently reported as Stichomitra sp. 1 by Ling and Lazarus, 1990, p. 356, pl. 5, fig. 11, from the late Aptian/earliest Albian interval of Hole 693A, in the Weddell Sea.

Occurrences. This form is known only from the "sand faunas" of Site 765 , Cores $51 \mathrm{R}-42 \mathrm{R}$ (Table 2). Its occurrence shows an acme in Cores 50R through 43R. Probably "circumantarctic" (see text).

Range. Barremian to early Aptian.

$$
\begin{aligned}
& \text { 6126 Parvicingulid sp. D } \\
& \text { (Pl. 8, Figs. 9-11) }
\end{aligned}
$$

Occurrences. This form is known only from the "sand faunas" of Site 765 , Cores $43 R$ to $42 R$ (Table 2). Its occurrence shows an acme in Core 42R. Probably "circumantarctic" (see text).

Range. Early Aptian.

6015 Genus PATELLULA Kozlova sensu Empson-Morin

Patellula Kozlova, 1972, p. 527; Empson-Morin, 1981, p. 257.

Type species. Stylospongia planoconvexa Pessagno, 1963, p. 199, pl. 3 , figs. 4-6; pl. 6, fig. 1 .

$$
\begin{aligned}
& 5287 \text { Patellula sp. A } \\
& \text { (P1. 10, Fig. 1) }
\end{aligned}
$$

Godia(?) sp. C Thurow, 1988, p. 401, pl. 5, fig. 15.

Occurrences. Tethyan, Atlantic, Indian Ocean: Site 765, Sample 123-765C-059R-1, 123-126 cm.

\section{Petasiforma sp. Pessagno}

Occurrences. Tethyan. Fragments observed in Sample 123-765C$51 \mathrm{R}-3,88-90 \mathrm{~cm}$. 
Range. Published: FO: Albian to Cenomanian. Indian Ocean: FO: Barremian.

3678 Genus PODOCAPSA Rüst, emend. Foreman

Podocapsa Rüst, 1885, p. 304, emend. Foreman, 1973, p. 267.

Type species. Podocapsa guembeli Rüst, 1885, (subsequent designation by Campbell, 1954, p. D122); Foreman (1973) designates Rüst's specimen of $P$. guembeli pl. 36, fig. 6, as the lectotype.

\section{Podocapsa amphitreptera Foreman}

(P1. 10, Fig. 9)

Podocapsa amphitreptera Foreman, 1973, p. 267, pl. 13, fig. 11; Foreman, 1975, p. 617, pl. 6, fig. 15; Muzavor, 1977, p. 112, pl. 7, fig. 4; Foreman, 1978, p. 749, pl. 1, fig. 16; Baumgartner et al., 1980, p. 61, pl. 3, figs. 8, 9; Kocher, 1981, p. 86, pl. 15, fig. 20; De Wever and Caby, 1981, p. 470, pl. II, fig. 2L; Yao et al., 1982, pl. 4, fig. 29; Baumgartner, 1984b, p. 780, pl. 7, figs. 9, 10; Schaaf, 1984, p. 90, 91, figs. 1-3b; Ozvoldova and Sykora, 1984, p. 269, pl. 11, figs. 2, 3, 6; Yao, 1984, pl. 3, fig. 14; Matsuoka and Yao, 1985, pl. 2, fig. 10; De Wever and Miconnet, 1984, p. 390, pl. 2, fig. 6; Sanfilippo and Riedel, 1985, p. 612, fig. 11.5; Matsuoka and Yao, 1986, pl. 2, fig. 17; De Wever et al., 1986, pl. 10, figs. 2, 3; Aita and Okada, 1986, p. 114, pl. 3, figs. 6, 7; Aita, 1987 , p. 66, pl. 12, fig. 3; Ozvoldova and Petercakova, 1987, pl. 34, fig. 8; Ozvoldova, 1988, pl. 4, fig. 1.

Nassellaria gen et sp. indet. Nakaseko and Nishimura, 1981, pl. 8, figs. $12 \mathrm{a}, 12 \mathrm{~b}$.

Occurrences. Tethyan, Indian Ocean: Site 765: Table 2.

Range. Published: Llate Jurassic to mid-Valanginian. Site 765: LO: late Hauterivian or early Barremian.

\section{Podocapsa sp. A}

$$
\text { (Pl. 10, Fig. 10) }
$$

Description, Remarks. Large, inflated form having comparably much shorter arms and terminal tube than $P$. amphitreptera. This form is likely to be a descendant of $P$. amphitreptera.

Occurrences. Argo Basin, Site 765: Table 2.

Range. Late Hauterivian to early Barremian.

\section{Genus PRAECONOCARYOMMA Pessagno}

Praeconocaryomma Pessagno, 1976, p. 40.

Type species. Praeconocaryomma universa Pessagno, 1976, p. 42, pl. 6 , figs. $14-16$.

\section{Praeconocaryomma sp. aff. P. prisca Pessagno}

$$
\text { (PI. 10, Figs. 11, 14) }
$$

Occurrences. This form is abundant in some "sand faunas" of Site 765, Cores 123-765C-59R to -56R (Table 2). and Site 766, Core 49R (Table 4). Its occurrence makes an acme in Cores 123-765C-57R to -56R.

\section{Praeconocaryomma(?) sp. A \\ (Pl. 10, Figs. 2-8)}

Occurrences. This form is known only from the "sand faunas" of Site 765 , Cores 123-765C-59R to -56R (Table 2). Its occurrence makes an acme in Core 58. (see Fig. 3). Probably "circumantarctic" (see text).

Range. Late Berriasian or earliest Valanginian to late Valanginian or early Hauterivian.

\section{Praeconocaryomma spp.}

$$
\text { (Pl. 10, Figs. 12, 13) }
$$

Description, Remarks. Includes all other forms assignable to this genus, not included under the species above.

Occurrences. Large, slightly knobby forms occur abundantly at Site 765 , Cores $-45 \mathrm{R}$ to $-43 \mathrm{R}$ (Table 2).

\section{Genus PSEUDODICTYOMITRA Pessagno}

Pseudodictyomitra Pessagno, 1977b, p. 50.

Type species. Pseudodictyomitra pentacolaensis Pessagno, 1977b, p. 50 , pl. 8 , figs. $3,17,23 ;$ pl. 12 , fig. 10
5625 Pseudodictyomitra lilyae (Tan Sin Hok)

Dictyomitra lilyae Tan Sin Hok, 1927, p. 55, pl. 10, fig. 83; Riedel and Sanfilippo, 1974 , p. 778 , pl. 4, figs. $7-9$, pl. 12, fig. 13; Renz, 1974 , p. 791 , pl. 8 , figs. $1-4$, pl. 11, fig. 33 .

Pseudodictyomitra lilyae Tan Sin Hok, Schaaf, 1981, p. 437, pl. 3, fig. 8 pl. 18 , figs. 5 a, 5b; Origlia-Devos, 1983, p. 177, pl. 20, figs. $8,9$.

Pseudodictyomitra(?) lilyae Tan Sin Hok, De Wever and Thiebault, 1981, p. 591 , pl. 1 , figs. $1-4$.

Archaeodictyomitra carpatica Lozynyak, Okamura and Uto, 1982, pl. 2, fig. 4.

Pseudodictyomitra carpatica Lozynyak, Suyari and Kuwano, 1986, pl. 1, figs. 5,6 .

Occurrences. Tethyan, Pacific, Indian Ocean: Site 260, Samples 260-12-2, 130-132 cm; Site 261, Samples 261-29-3, 41-43 cm (questionably), consistent range: Samples 261-23-CC to 261-9-3, 90-92 cm. Site 765 , Samples 123-765C-50R-3, 111-115 cm, to $-42 \mathrm{R}-4,148-150 \mathrm{~cm}$.

Range. Published: late Valanginian to top of Hauterivian. Indian Ocean: Valanginian(?)-Barremian to Aptian or younger.

\section{Genus PSEUDOEUCYRTIS Pessagno}

Pseudoeucyrtis Pessagno, 1977b, p. 58.

Type species. Eucyrtis(?) zhamoidai Foreman, 1973, p. 264, pl. 10, figs. 9,10 , pl. 16 , figs. 1,2 .

\section{Pseudoeucyrtis sp. A \\ (Pl. 11, Figs. 7-9)}

Description, Remarks. Spindle-shaped form without strictures, small apical horn, proximally broadly conical to dome-shaped, distally slender, conical, or slightly tapering. Porous down to small terminal spine. Uniform large polygonal (sometimes hexagonal) pore frames, sometimes with transverse rows of pores.

Occurrences. This form is known only from the "sand faunas" of Site 765, Cores 123-765C-59R to -54R (Table 2). Its occurrence shows an acme in Cores 57R and 55R (see Fig. 3). Probably "circumantarctic" (see text).

Range. Late Berriasian or earliest Valanginian to late Hauterivian or early Barremian.

\section{Pseudoeucyrtis sp. B}

$$
\text { (PI. 11, Figs. 3-6) }
$$

Description, Remarks. Large spindle-shaped form with indistinct strictures, small apical horn. Proximal portion broadly conical; domeshaped, median portion almost cylindrical; distal portion with at least one narrower segment, tapering into a long, distally poreless terminal tube. Irregular large polygonal pore frames.

Occurrences. This form is known only from the "sand faunas" of Site 765, Cores 123-765C-58R to -54R (Table 2). Its occurrence shows an acme in Core 54R (see Fig. 3). Probably "circumantarctic" (see text).

Range. Late Berriasian or earliest Valanginian to late Hauterivian or early Barremian.

\section{Pseudoeucyrtis sp. C}

(Pl. 10, Figs. 1, 2)

Description, Remarks. Large slenderly conical form with distinct strictures, small apical horn. Proximal and median portion slender conical, distal portion having at least one narrower segment, followed by a rarely preserved short terminal tube. Irregular large polygonal pore frames.

Occurrences. This form is known only from the "sand faunas" of Site 765, Cores 123-765C-57R to -53R (Table 2). Probably "circumantarctic" (see text).

Range. Valanginian to late Hauterivian or early Barremian.

3687 Genus RISTOLA Pessagno and Wahlen sensu Baumgartner Ristola Pessagno and Wahlen, 1982, p. 148; Baumgartner, 1984b, p. 783.

Type species. Parvicingula(?) procera Pessagno, 1977a, p. 86, pl. 9 , figs. 6-9.

Remarks. In contrast to the definition by Pessagno and Wahlen (1982), I include species, with or without apical horn, based on the 
presence of an outer layer obscuring the hexagonal pore arrangement of the proximal portion of the test (Baumgartner, 1984b).

$$
\begin{gathered}
5632 \text { Ristola } \text { sp. A } \\
\text { (Pl. 10, Figs. 10-14) }
\end{gathered}
$$

aff. Parvicingula(?) blowi Pessagno, Vishnevskaya, 1988, pl. 8, fig. 9.

Description, Remarks. Large conical form with dome-shaped proximal portion. Cephalis, thorax, abdomen, and one or two post-abdominal segments form a dome-shaped portion without external segmental divisions. Cephalis bears a slender horn. Dome-shaped portion with an outer layer consisting of uniform polygonal meshwork of raised ridges and nodes at intersections. Pores and frames getting larger distally. Remaining 10 to 12 post-abdominal segments form a long conical portion with segmental divisions marked by circumferential ridges formed by raised pore frames. Usually three rows of pores per segment in hexagonal arrangement. As with other Ristola, some specimens show the polygonal meshwork of the proximal portion gradually disappearing on the conical portion. Vishnevskaya (1988) illustrateD a similar form from the Late Jurassic of the Northwest Pacific.

Occurrences. This form is known only from the "sand faunas" of Site 765 , Cores $123-765$ C-59R to -58R (Table 2). Probably "circumantarctic" (see text).

Range. Late Berriasian to earliest Valanginian.

\section{Genus SETHOCAPSA Haeckel}

Sethocapsa Haeckel, 1881, p. 433.

Type species. Sethocapsa cometa (Pantanelli) in Rüst, 1885, p. 306 , pl. 36(11), fig. 15 (subsequent designation by Foreman, 1973, p. 267).

\section{Sethocapsa cetia Foreman}

$$
\text { (Pl. 12, Fig. 1) }
$$

Sethocapsa cetia Foreman, 1973, p. 267, pl. 12, fig. 1; pl. 16, fig. 19; Foreman, 1975, p. 617, pl. 6, fig. 14; Muzavor, 1977, p. 114, pl. 5, fig. 4; Foreman, 1978, p. 749, pl. 2, fig. 1; Baumgartner et al., 1980, p. 61, pl. 3, fig. 14; Kocher, 1981,p. 89, pl. 16, figs. 4, 5; Baumgartner, 1984b, p. 784, pl. 8, fig. 13; Ozvoldova and Sykora, 1984, p. 271, pl 5, fig. 8; Schaaf, 1984, p. 154, fig. 4; Schaaf, 1985, p. 266; Sanfilippo and Riedel, 1985, p. 613, fig. 10.5; Aita and Okada, 1986, p. 114, pl. 3, fig. 8; Aita, 1987, p. 66, pl. 14, fig. 12; Ozvoldova and Petercakova, 1987, pl. 34, fig. 6; Pavsic and Gorican, 1987, p. 28, pl. 4, fig. 9; Ozvoldova, 1988, pl. 4, figs. 6, 7.

Obesacapsula cetia (Foreman) non Pessagno, 1977a, p. 87, pl. 11, fig. 4; non Pessagno, 1977b, p. 52, pl. 9, fig. 11.

Occurrences. Tethyan, Indian Ocean: Site 765: Table 2.

Range. Published: Late Jurassic to Valanginian.

\section{Sethocapsa dorysphaeroides Neviani}

$$
\text { (Pl. 11, Fig. 5) }
$$

Sethocapsa dorysphaeroides Neviani, 1900; Schaaf, 1984, p. 155, figs. $6 \mathrm{a}, 6 \mathrm{~b}$.

Occurrences. Tethyan, Pacific, Indian Ocean: Site 765: Table 2. Range. Site 765: Berriasian to late Hauterivian or early Barremian.

\section{Sethocapsa leiostraca Foreman}

(PI. 11, Figs. 2, 3)

Sethocapsa leiostraca Foreman, 1973, p. 268, pl. 12, figs. 5, 6; Foreman, 1975 , p. 617 , pl. 2J, fig. 5; Kocher, 1981, p. 89, pl. 16, fig. 6; Baumgartner, 1984b, p. 784; Ozvoldova and Sykora, 1984, p. 271, pl. 13, fig. 4; Ozvoldova and Petercakova, 1987, pl. 35, fig. 2.

Sethocapsa trachyostraca Foreman, (?) Baumgartner et al., 1980, p. 61 , pl. 6, fig. 2.

Occurrences. Tethyan, Indian Ocean: Site 765: Table 2.

Range. Published: Llate Jurassic to late Hauterivian. Site 765: LO: Barremian.

\section{Sethocapsa orca Foreman}

(Pl. 11, Fig. 4)

Sethocapsa orca Foreman, Schaaf, 1975, p. 154, figs. 8a, 8 b.

Theoperid gen. and sp. indet., Foreman, 1973, pl. 12, fig. 3, pl. 14, fig. 20.

Sethocapsa(?) orca Foreman, 1975, p. 617 , pl. 2J, figs. 1, 2, pl. 6, fig. 12; Schaaf, 1981, p. 437, pl. 26, figs. 3a, 3b.

Occurrences. Tethyan, Indian Ocean: Site 765: Table 2.

Range. Site 765: late Berriasian.

\section{Sethocapsa trachyostraca trachyostraca Foreman}

Sethocapsa trachyostraca Foreman, 1973, p. 268, pl. 12, fig. 4; Foreman 1975 , p. 617 , pl. 2J, figs. 3, 4; Muzavor, 1977 , p. 119 , pl. 6 , fig. 5 ; Foreman, 1978, p. 749, pl. 1, fig. 18; non Baumgartner et al., 1980 , pl. 6, fig. 2; Schaaf, 1981 , p. 437, pl. 21, figs. 1a-1b; non Kocher 1981 , pl. 16, figs. 9, 10; Baumgartner, 1984 b, p. 784 , pl. 8 , fig. 14 Aita and Okada, 1986, p. 118, pl. 3, figs. 9, 10; Kito, 1987, pl. 2, fig. 5; Pavsic and Gorican, 1987, p. 29, pl. 4, fig. 8; Iwata and Tajika, 1989 , pl. 4 , fig. 1 .

Sethocapsa cf. trachyostraca Foreman, Ozvoldova and Petercakova, 1987, p. 122 , pl. 35 , fig. 3 .

Occurrences. Tethyan, Atlantic, Pacific. Isolated occurrences at Site 765, Samples 123-765C-54R-CC to -43R-3, 98-102 cm.

Range. Published: Late Jurassic to Hauterivian. Site 765: late Hauterivian or early Barremian to Aptian.

\section{Sethocapsa sp. A}

(Pl. 11, Fig. 6)

Occurrences. Tethyan, Indian Ocean: Site 765: Table 2.

6129 Sethocapsa sp. B

(Pl. 11, Fig. 7)

Description, Remarks. Relatively large form with a distinct depression on the top of the spherical post-abdominal segment. Forms with such depressions were illustrated by Aita (Spörli and Aita, 1988) from the Upper Jurassic of Kawakawa Bay, New Zealand.

Occurrences. Site 765: Table 2. Probably "circumantarctic."

Range. Site 765: late Berriasian to Valanginian.

\section{Sethocapsa spp.}

Description, Remarks. Includes all other forms assignable to Sethocapsa.

\section{Genus SPONGOCAPSULA Pessagno}

Spongocapsula Pessagno, 1977a, p. 88

Type species. Spongocapsula palmerae Pessagno, 1977a, p. 88, pl. 11 , figs. $12-14,16$.

$$
6122 \text { Spongocapsula(?) sp. A }
$$

(Pl. 12, Figs. 13, 14)

Description, Remarks. Conical form with well-defined strictures on distal part. Last preserved segment is widest, no extension preserved. Pore frames coarse polygonal, pores shallow, very small, circular, one to several within one frame. No distinct transverse or longitudinal rows.

Occurrences. This form is known only from the "sand faunas" of Site 765 . Cores 59R to 54R (Table 2). Probably "circumantarctic" (see text).

Range. Late Berriasian to late Hauterivian or early Barremian.

\section{Spongocapsula(?) sp. B}

$$
\text { (Pl. 12, Figs. 11, 12) }
$$

Description, Remarks. Conical form with well-defined strictures on distal part. Second last segment is widest, last segment much narrower, cup shaped, bearing a rarely preserved short extension. Pore frames coarse polygonal, pores depressed large circular or polygonal. No distinct transverse or longitudinal rows. 
Occurrences. This form is known only from the "sand faunas" of Site 765, Cores 59R to 58R (Table 2). Probably "circumantarctic" (see text).

Range. Late Berriasian or early Valanginian.

\section{Genus SPONGOTRIPUS Haeckel}

Spongotripus Haeckel, 1881, p. 461.

Type species. Spongotripus regularis Haeckel, 1887, p. 580.

5901 Spongotripus trigonus Rüst

(Pl. 12, Figs. 9, 10, 15)

Spongotripus trigonus Rüst, 1898, p. 34, pl. 11, fig. 13.

Paronaella sp. A Mizutani et al., 1982, p. 61, pl. 6, fig. 2.

Occurrences. Tethyan, Indian Ocean: Site 765: Table 2.

Range. Aptian.

\section{Genus STEPHANASTRUM Ehrenberg}

Stephanastrum Ehrenberg, 1847, p. 54.

Type species. Stephanastrum rhombus Ehrenberg, 1854, pl. 36, fig. 33 (?subsequent designation by Campbell, 1954, p. D88).

\section{Stephanastrum inflexum Rüst}

(Pl. 13, Figs. 1, 2)

Stephanastrum inflexum Rüst, 1898, p. 32, pl. 11, fig. 2; Schaaf, 1981, p. 439 , pl. 14 , figs. $4 a, 4 b$.

Hagiastrid 2 gen. and sp. indet., Renz, 1974, p. 792, 793, pl. 1, fig. 9.

Occurrences. Tethyan, Atlantic, Indian Ocean: Sites 260, 261, Site 765: Table 2.

Range. Late Barremian(?) to Aptian.

\section{Stephanastrum orbiculare Rüst}

(Pl. 13, Figs. 3, 8)

Stephanastrum orbiculare Rüst, 1898, p. pl. 10, fig. 10.

Occurrences. Tethyan, Indian Ocean: Site 765: Table 2.

Range. Barremian to Aptian.

\section{Genus STICHOCAPSA Haeckel}

Stichocapsa Haeckel, 1881, p. 439.

Type species. Stichocapsa jaspidea Rüst, 1885, p. 317, pl. 41, fig. 6 .

\section{Stichocapsa perspicua Squinabol}

(Pl. 13, Figs. 4, 5)

Cyrtocapsa perspicua Squinabol.

Stichocapsa euganea Squinabol, 1903, p. 142, pl. 8, fig. 30.

Description, Remarks. Two morphotypes are included because there are many transitional forms. One has a flat basal surface with a large opening (Pl. 13, Fig. 4), the other has a cup-shaped terminal segment with a small opening and ragged relics of a terminal tube(?). It is possible that the first form is not complete.

Occurrences. Tethyan, Atlantic, Pacific, Indian Ocean: Site 765: Table 2.

Range. Published: Aptian, Indian Ocean: FO: late Hauterivian to early Barremian.

\section{Genus TRIACTOMA Rüst}

Triactoma Rüst, 1885, p. 289.

Type species. Triactoma tithonianum Rüst, 1885, p. 289, pl. 28(3), fig. 5 (subsequent designation by Campbell, 1954, p. D81).

\section{Triactoma echiodes Foreman}

Triactoma echiodes Foreman, 1973, p. 260, pl. 3, fig. 1, pl. 16, fig. 21; Foreman, 1975, p. 609, pl. 2F, figs. 9-10; pl. 3, fig. 10; Baumgartner et al., 1980 , p. 64 , pl. 2, fig. 10 ; Kocher, 1981, p. 101, pl. 17, figs. 8 , 9; Kanie et al., 1981, pl. 1, fig. 7; Baumgartner, 1984b, p. 789, pl. 10, fig. 2; Schaaf, 1984, p. 108, 109, figs. 1, (?)2, (?)3, 4;
Triactoma sp. cf. T. echiodes Foreman, 1973, p. 260, pl. 3, figs. 2, 3; Ozvoldova and Sykora, 1984, p. 272, pl. 13, fig. 3; Aita, 1987, p. 64, pl. 12 , fig. 9.

Occurrences. Tethyan, Atlantic, Pacific, Indian Ocean: Site 765, Sample 123-765C-52R-3, 57-61 cm, very rare.

Range. Indian Ocean: early Barremian.

\section{Genus TRICOLOCAPSA Haeckel}

Tricolocapsa Haeckel, 1881, p. 436.

Type species. Tricolocapsa theophrasti Haeckel, 1887.

\section{Tricolocapsa sp. A}

$$
\text { (PI. 13, Figs. 6, 7) }
$$

Description, Remarks. Form with broad cephalis and thorax and distinct vertical rows of pores on abdomen.

Occurrences. Site 765, Table 2. Present in "clay faunas," indigenous to Indian Ocean.

Range. Late Tithonian(?)-Berriasian.

\section{Tricolocapsa $\mathrm{sp} . \mathrm{B}$ \\ (PI. 13, Fig. 9)}

Description, Remarks. Form with hemispherical cephalis, domeshaped thorax and flattened ellipsoidal abdomen with a small terminal appendage. Regular pentagonal to hexagonal pore frames around small circular pores.

Occurrences. Site 765: Table 2. Present in "clay faunas"; indigenous to Indian Ocean.

Range. Late Tithonian-Berriasian to Barremian.

\section{Tricolocapsa spp.}

Remarks. Includes all forms not assigned to a particular species. Occurrences. Site 765: Table 2.

Range. Early Cretaceous.

\section{Tripocalpis laboriosus Tan Sin Hok}

$$
\text { (Pl. 13, Fig. 10) }
$$

Tripocalpis laboriosus Tan Sin Hok, 1927, p. 38, pl. 7, figs. 17a, 17b.

Occurrences. Tethyan, Indian Ocean: Roti, Site 765: Table 2.

Range. Late Tithonian-Berriasian to Barremian.

\section{Vitorfus brustolensis (Squinabol)}

Saturnalis brustolensis Squinabol, 1903, p. 112, pl. 10, fig. 4; Pessagno, 1977 , p. 35 , pl. 3 , fig. 9.

Saturnalis lateralis Campbell and Clark, 1944, p. 6, pl. 1, figs. 7, 10, 11, $13,15$.

Spongosaturnalis sp. aff. Saturnalis lateralis group (Campbell and Clark) Renz, 1974, p. 797, pl. 2, figs. 1-4, pl. 9, fig. 15.

Occurrences. Tethyan, Atlantic, Indian Ocean: Site 260, Sample 260-11-1, 113-115 cm. Site 261, Samples 261-16-1, 101-103 cm, to Sample 261-9-3, 90-92 cm (rare to few). Site 765. Sample 123-765C$42 \mathrm{R}-4,148-150 \mathrm{~cm}$ (rare).

Range. Published: Late Cretaceous. Indian Ocean: FO: Aptian.

\section{Genus XITUS Pessagno}

Xitus Pessagno, 1977b, p. 55.

Type species. Xitus plenus Pessagno, 1977b, p. 55, pl. 9, figs. 15, 21, 22, 26; pl. 12, fig. 15.

3676 Xitus spp.

$$
\text { (Pl. 13, Figs. 11-13) }
$$

Remarks. Includes several species found also in Tethyan assemblages.

Occurrences. Tethyan, Atlantic, Pacific, Indian Ocean: Site 765: Table 2. Could be a cosmopolitan group. 


\section{REFERENCES}

Aarseth, I., Bjerkli, D., Bjorklund, K. R., Boe, D., Helm, J. P., LorentzenStyr, T. J., Myhre, L. A., Ugland, E. S., and Thiede, J., 1975. Late Quaternary sediments from Korsfjorden, western Norway. Sarsia. $58: 43-66$.

Aita, Y., 1987. Middle Jurassic to Lower Cretaceous radiolarian biostratigraphy of Shikoku with reference to selected sections in Lombard. Sci. Rep. Tokoku Univ., Ser. 2, 58:1-91.

Aita, Y., and Okada, H., 1986. Radiolarians and calcareous nannofossils from the uppermost Jurassic and lower Cretaceous strata of Japan and Tethyan regions. Micropaleontology, 32:97-128.

Aliev, K. S., 1961. Novye vidy Radiolyarii nizhnemelovykh otlozhenii Servero-Vostochnozo Azerbaidzhana (New radiolarian species of the Lower Cretaceous deposits of northeastern Azerbaidzhan). Izvest. Akad. Nauk Azerbaidzh. SSR, Ser. Geol.-Geogr. Nauk Nefti, 1:51-65. 1965. Radiolyarii nizhnemelovykh otlozheni severo-vostochnogo Azerbaidzhana i ikh stratigraficheskoe znachenie (Radiolarians of the Lower Cretaceous deposits of northeastern Azerbaidzhan and their stratigraphic significance), Baku, Azerbaidzhanskoi SSR, Izdatel. Akad. Nauk, 1-124.

Aoki, T., 1982. Upper Jurassic to Lower Cretaceous radiolarians from the Tsukimiyama and Tei Melanges of the northern Shimanto Belt in Kochi Prefecture, Shikoku. In Nakaseko, K. (Ed.), Proc, Ist Jpn. Radiolarian Symp., News of Osaka Micropaleontol., Spec. Vol., 5:339-351.

Baumgartner, P. O., 1980. Late Jurassic Hagiastridae and Patulibracchiidae (Radiolaria) from the Argolis Peninsula (Peleponnesus, Greece). Micropaleontology, 26:274-322.

1984a. Comparison of unitary associations and probabilistic ranking and scaling as applied to Mesozoic radiolarians. Comput. Geosci., 10:167-183.

1984b. A middle Jurassic-Early Cretaceous low-latitude radiolarian zonation based on Unitary Associations and age of Tethyan radiolarites. Eclogae Geol. Helv., 77:729-837.

1987: Age and genesis of Tethyan Jurassic radiolarites. Eclogae Geol. Helv., 80:831-879.

Baumgartner, P., De Wever, P., and Kocher, R., 1980. Correlation of Tethyan Late Jurassic-Early Cretaceous radiolarian events. Cah. Micropaleontol., 2:23-86.

Campbell, A. S., 1954. Radiolaria. In Moore, R. C. (Ed.), Treatise on Invertebrate Paleontology, Part D, Protista 3. Geol. Soc. Am. and Univ. of Kansas Press, D11-D195.

Campbell, A. S., and Clark, B. L., 1944. Radiolaria from Upper Cretaceous of Middle California.Spec. Pap.-Geol.Soc. Am., 57:i-viii and 1-61.

Casey, R. E., 1971. Radiolarians as indicators of past and present watermasses. In Funnell, B. M., and Riedel, W. R. (Eds.), The Micropalaeontology of Oceans: Cambridge (Cambridge Univ. Press), $331-341$.

Ciarapica, G., and Zaninetti, L., 1982. Faune à Radiolaires dans la séquence triasique/liasique de Grotta Arpaia, Portovenère (la Spezia), Apennin septentrional (Radiolarians of Triassic/Liassic in Grotta Arpaia, Portovenere, La Spezia, Northern Apennines). Rev. Paleobiol., 1:165-179.

Cita, M. B., and Pasquare, G., 1959. Studi stratigrafici sul sistema Cretaceo in Italia. Nota IV. Osservazioni micropaleontoligiche sul Cretaceo delle Dolomiti. Riv. Ital. Paleontol. Stratigr., 65:385-443.

De Wever, P., and Caby, R., 1981. Datation de la base des schistes lustrés postophiolitiques par des radiolaires (Oxfordien supérieur-Kimmeridgien moyen) dans les Alpes Cottiennes (Saint-Veran, France). $C$. R. Acad. Sci. Ser. 2, 292:467-472.

De Wever, P., Geyssant, J. R., Azéma, J., Devos, I., Duée, G., Manivit, H., and Vrielynck, B., 1986. La coupe de Santa Anna (zone de Sciacca, Sicile): une synthèse biostratigraphique des apports des macro-, micro- et nannofossiles du Jurassique supérieur et Crétacé inférieur. Rev. Micropaleontol., 29:141-186.

De Wever, P., and Miconnet, P., 1984. Datations directes des radiolarites du bassin du Lagonero (Lucanie, Italie méridionale) Implications et conséquences. Rev. Espan. Micropaleontol., 17:373-402.

De Wever, P., and Thiebault, F., 1981. Les Radiolaires d'age Jurassique supérieur à Crétacé supérieur dans les radiolarites du Pinde-Olonos (Presqu’ile de Koroni; Péloponnèse méridional, Greece) (Radiolaria of Upper Jurassic to Upper Cretaceous age in the radiolarites of
Pindus-Olonus, Koroni Peninsula, southern Peloponnesus, Greece). Geobios, 14:577-609.

Donofrio, D., and Mostler, H., 1978. Zur Verbreitung der Saturnalidae (Radiolaria) im Mesozoikum der Nordlichen Kalkalpan und Sudalpen. Geol.-Palaontol. Mitt. Innsbruck, 7:1-55.

Dumitrica, P., 1970. Cryptocephalic and cryptothoracic Nassellaria in some Mesozoic deposits of Romania. Rev. Roumaine Geol., Geophys. Geogr., Ser. Geol., 14:45-124.

Dyer, R., and Copestake, P., 1989. A review of Late Jurassic to earliest Cretaceous radiolaria and their biostratigraphic potential to petroleum exploration in the North Sea. In Batten, D. J., and Keen, M, C. (Eds.), Northwest European Micropalaeontology and Palynology: London (Ellis Horwood, Micropalaeontol. Soc. Ser.), 214-235.

Ehrenberg, C. G., 1847. Uber eine halibiolithische, von Herrn R. Schomburgk entdeckte, vorherrschend aus mikroskopischen Polycystinen gebildete, Gebirgsmasse von Barbados. K. Preuss. Akad. Wiss. Berlin, Bericht, Jahre 1846:382-385.

1854. Die systematische Charakteristik der neuen mikroskopischen Organismen des tiefen atlantischen Oceans. K. Preuss. Akad. Wiss. Berlin, Bericht, Jahre 1854:236-250.

1875. Fortsetzung der mikrogeologischen Studien als Gesammt-Uebersicht der mikroskopischen Paläontologie gleichartig analysirter Gebirgsarten der Erde, mit specieller Rücksicht auf den Polycystinen-Mergel von Barbados. Abh.K. Akad. Wiss. Berlin, Jahre 1875:1-225.

Empson-Morin, K., 1981. Campanian Radiolaria from DSDP Site 313, Mid-Pacific Mountains. Micropaleontology, 27:249-292.

1982. Reexamination of the late Cretaceous radiolarian genus Amphipyndax Foreman. J. Paleontol., 56:507-519.

Fischli, H., 1916. Beitrag zur Kenntnis der fossilen Radiolarien in der Riginagelfluh (Contribution to the knowledge of fossil Radiolaria of Riginagelfluh). Mitt. Naturwiss. Ges. Winterthur, Jahrg. 1915-1916, 11:44-47.

Foreman, H. P., 1966. Two Cretaceous radiolarian genera. Micropaleontology, 12:355-359.

1968. Upper Maestrichtian radiolaria of California. Palaeontol. Assoc., London, Spec. Pap. Palaeontol., 3:1-82.

1973. Radiolaria from DSDP Leg 20. In Heezen, B. C., MacGregor, I. D., et al., Init. Repts. DSDP, 20: Washington (U.S. Govt. Printing Office), 249-305.

1975. Radiolaria from the North Pacific, Deep Sea Drilling Project, Leg 32. In Larson, R. L., Moberly, R., et al., Init. Repts. DSDP, 32: Washington (U.S. Govt. Printing Office), 579-676.

1978. Mesozoic Radiolaria in the Atlantic Ocean off the northwest coast of Africa, Deep Sea Drilling Project, Leg 41. In Lancelot, Y., Seibold, E., et al., Init. Repts. DSDP, 41: Washington (U.S. Govt. Printing Office), 739-761.

Haeckel, E., 1881. Entwurf eines Radiolarien-Systems auf Grund von Studien der Challenger-Radiolarien (Basis for a radiolarian classification from the study of Radiolaria of the Challenger collection). Jena. Z. Naturwiss., 15:418-472.

1887. Report on the Radiolaria collected by H.M.S. Challenger during the years 1873-1876. Rep. Sci. Results Voy. H.M.S. Challenger 1873-1876, Zool., 18.

Haq, B. U., Hardenbol, J., and Vail, P. R., 1988. Chronology of fluctuating sea levels since the Triassic. Science, 235:1156-1166.

Hinde, G. J., 1900. Description of fossil Radiolaria from the rocks of Central Borneo. In Molengraaff, G.A.F. (Ed.), Borneo-Expeditie: Geologische Verkenningstochten in Centraal Borneo (1893-94): Leiden (E. J. Brill and H. Gerlings), 1-56.

Holzer, H. L., 1980. Radiolaria aus Atzruckstanden des Malm und der Unterkreide der Nordlichen Kalkalpen (Osterreich) (Radiolaria from acid residues of Malm and Lower Cretaceous rocks of the northern Limestone Alps [Austria]). Ann. Naturhist. Mus. Wien, 83:153-167.

Igo, H., Sashida, K., and Ueno, H., 1987. Early Cretaceous radiolarians from the Esashi Mountains, northern Hokkaido. Ann. Rep. Inst. Geoscience, Univ. Tsukuba, 13:105-109.

Iwata, K., and Tajika, J., 1989. Jurassic and Cretaceous radiolarians from the pre-Tertiary system in the Hidaka Belt, Maruseppu region, Northeast Hokkaido. J. Fac. Sci., Hokkaido Univ., Series 4: Geol. Mineral., 22:453-466.

Jud, R., 1989. Lower Cretaceous radiolarian biostratigraphy in Umbria and southern Alps. Abstr. 1st Meet. Urbino, Italy, Work. Gr., 2:45-48. 
Kanie, Y., Taketani, Y., Sakai, A., and Miyata, Y., 1981. Lower Cretaceous deposits beneath the Yezo group in the Urakawa area, Hokkaido. Chishitsugaku Zashhi, 87:527-533.

Kato, Y., and Iwata, K., 1989. Radiolarian biostratigraphic study of the pre-Tertiary system around the Kamikawa Basin, central Hokkaido, Japan. J. Fac. Sci., Hokkaido Univ., Ser. 4: Geol. Mineral., 22:425452.

Kito, N., 1987. Stratigraphic relation between greenstones and clastic sedimentary rocks in the Kamuikotan Belt, Hokkaido, Japan. Chishitsugaku Zasshi, 93:21-35.

Kocher, R. N., 1981. Biochronostratigraphische Untersuchungen oberjurassischer radiolarien fuhrender Gesteine, insbesondere der Sudalpen. Mitt. Geol. Inst. Eidgenossischen Technisch. Hochschule Univ. Zurich, Neue Folge, 234:1-184.

Kozlova, G. E., 1972. A find of Radiolaria in the lower Kimmeridgian of the Timan-Ural region. Dokl. Akad. Nauk USSR, Earth Sci. Sect., 201:118-120.

Ling, H. Y., and Lazarus, D. B., 1990. Cretaceous radiolaria from the Weddell Sea: Leg 113 of the Ocean Drilling Program. In Barker, P. F., Kennett, J. P., et al., Proc. ODP, Sci. Results, 113:353-363.

Lipman, R. K., 1952. Materialy k monograficheskomu izucheniyu radiolyarii verkhnemelovykh otlozhenii Russkoi Platformy (Data on the monographic study of the radiolarians of the Upper Cretaceous deposits of the Russian Platform). Trudy Vses. Nauchno-Issled. Geolog. Inst. (VSEGEI), Paleontol. Stratigr. (Trans. All Union Sci. Res. Inst. Geol., Paleontol. Stratigr.), 24-51.

Ludden, J. N., Gradstein, F. M., et al., 1990. Proc. ODP, Init. Repts., 123: College Station, TX (Ocean Drilling Program).

Matsuoka, A., and Yao, A., 1985. Latest Jurassic radiolarians from the Torinosu Group in Southeast Japan. J. Geosci., Osaka City Univ., 28:125-145.

1986. A newly proposed radiolarian zonation for the Jurassic of Japan. Mar. Micropaleontol., 11:91-106,

Matsuyama, H., Kumon, F., and Nakajo, K., 1982. Cretaceous radiolarian fossils from the Hidakagawa Group in the Shimanto Belt, Kii Peninsula, southwest Japan. In Nakaseko, K. (Eds.), Proc. Ist Jpn. Radio larian Symp., News Osaka Micropaleontol., Spec. Vol., 5:371-382.

Mizutani, S., 1981. A Jurassic formation in the Hida-Kanayama Area, Central Japan. Bull. Mizunami Foss. Mus., 8:147-190.

Mizutani, S., Nishiyama, H., and Ito, T., 1982. Radiolarian biostratigraphic study of the Shimanto Group in the Nanto-Nansei area, Mie Prefecture, Kii Peninsula, central Japan. J. Earth Sci., Nagoya Univ., 30:31-107.

Moore, T. C., 1973. Radiolaria from Leg 17 of the Deep Sea Drilling Project. In Winterer, E. L., Ewing, J. I., et al., Init. Repts. DSDP, 17: Washington (U.S. Govt. Printing Office), 797-869.

Murchey, B., 1984. Biostratigraphy and lithostratigraphy of cherts in the Franciscan Complex, Marin Headlands, California. In Blake, M. (Ed.), Franciscan Geology of Northern California. Pacific Sect., Soc. Econ. Paleontol. Mineral., 51-70.

Muzavor, S.N.X., 1977. Die oberjurassische Radiolarienfauna von Oberaudorf am Inn [Dissert.]. Ludwig-Maximilians-Univ., Munchen.

Nakagawa, C., Nakaseko, K., Kawaguchi, K., and Yoshimura, R., 1980. Radiolarian fossils from the upper Jurassic and Cretaceous formations of the Shimanto belt in the eastern part of Shikoku-a study of the Shimanto belt in the eastern part of Shikoku (no. 4). J. Tokushima Univ., Nat. Sci., 31:1-27.

Nakaseko, K., Matsushima, N., Obata, I., and Matsukawa, M., 1979. Geological age of the Misakubo and the Wada Formations in the Akaishi Mountains. Natural history of the southern part of the Japanese Alps and the Kii Peninsula, including the Tokai District. Mem. Nat. Sci. Mus. (Tokyo), 12:65-72.

Nakaseko, K., and Nishimura, A., 1981. Upper Jurassic and Cretaceous Radiolaria from the Shimanto Group in Southwest Japan. Sci. Rep., Coll. Gen. Educ., Osaka Univ., 30:133-203.

Neviani, A., 1900. Supplemento alla fauna a Radiolari delle rocce mesozoiche del Bolognese (Additional observations of the radiolarian fauna of the Mesozoic rocks of the Bologna area). Boll. Soc. Geol. Ital., 19:645-671.

Nigrini, C., 1967. Radiolaria in pelagic sediments from the Indian and Atlantic Oceans. Bull. Scripps Inst. Oceanogr., 11:1-125.

Okamura, M., 1980. Radiolarian fossils from the northern Shimanto Belt (Cretaceous) in Kochi Prefecture, Shikoku. In Rinya-Koseikai (Ed.), Geology and Paleontology of the Shimanto Belt: 153-178.
Okamura, M., and Matsugi, H., 1986. Cretaceous radiolarians from the time equivalent formations of the arc-trench system, Shikoku. In Recent Progress of Research on Radiolarians and Radiolarian Terranes of Japan. News Osaka Micropaleontol., Spec. Vol., 7:117-129.

Okamura, M., and Uto, H., 1982. Notes on stratigraphic distributions of radiolarians from the Lower Cretaceous sequence of chert in the Yokonami Melange of Shimanto Belt, Kochi Prefecture, Shikoku. Res. Rep. Kochi Univ., Nat. Sci., 31:87-94.

Origlia-Devos, 1., 1983. Radiolaires du Jurassique supérieur-Crétacé inférieur: taxonomie et revision stratigraphique (zone du Pinde-Olonos, Grece, zone de Sciacca, Italie, Complexe de Nicoya, Costa Rica et forages du DSDP [Diplome de Docteur de 3eme Cycle]. Univ. Pierre et Marie Curie, Paris.

Ozvoldova, L., 1979. Radiolarian assemblage of radiolarian cherts of Podbiel locality (Slovakia). Cas. Mineral. Geol., 24:249-261.

1988. Radiolarian associations from radiolarites of the Kysuca succession of the Klippen Belt in the Vicinity of Myjava-Tura Luka (West Carpathians). Geol. Carpathica, 39:369-392.

Ozvoldova, L., and Petercakova, M., 1987. Biostratigraphic research of upper Jurassic limestones of the Cachtice Carpathians (locality Bzince pod Javorinou). Zapadne Karpaty, Ser. Paleontol., 12:115-124.

Ozvoldova, L., and Sykora, M., 1984. The radiolarian assemblage from Cachticke Karpaty Mts. limestones (the locality Sipkovsky Haj). Geol. Sborn., 35:259-290.

Parona, C. F., 1890. Radiolarie nei noduli selciosi del calcare giurese di Cittiglio presso Laverno (Radiolarians from siliceous nodules of the Jurassic limestones of Cittiglio near Laverno). Boll. Soc. Geol. Ital., 9:132-175.

Pavsic, J., and Gorican, S., 1987. Lower Cretaceous nannoplankton and radiolaria from Vrsnik (western Slovenia). Razprave IV. Razreda Sazu, 27:15-36.

Pessagno, E. A., 1963. Upper Cretaceous Radiolaria from Puerto Rico. Micropaleontology, 9:197-214

1969. The Neosciadiocapsidae, a new family of Upper Cretaceous Radiolaria. Bull. Am. Paleontol., 56:377-439.

1971. Jurassic and Cretaceous Hagiastridae from the Blake-Bahama Basin (Site 5A, JOIDES Leg 1) and the Great Valley Sequence, California Coast Ranges. Bull. Am. Paleontol., 60:5-83.

1973. Upper Cretaceous Spumellariina from the Great Valley Sequence, California Coast Ranges. Bull. Am. Paleontol., 63:49-102.

, 1976. Radiolarian zonation and stratigraphy of the Upper Cretaceous portion of the Great Valley Sequence, California Coast Ranges. Micropaleontol., Spec. Publ., 2:1-95.

1977a. Upper Jurassic Radiolaria and radiolarian biostratigraphy of the California Coast Ranges. Micropaleontology, 23:56-113. 1977b. Lower Cretaceous radiolarian biostratigraphy of the Great Valley Sequence and Franciscan Complex, California Coast Ranges. Spec. Publ. Cushman Found. Foraminiferal Res., 15:1-87.

Pessagno, E. A., Blome, C., and Longoria, J., 1984. A revised radiolarian zonation from Upper Jurassic of western North America. Bull. Am. Paleontol., 87.

Pessagno, E. A., and Blome, C. D., 1986. Faunal affinities and tectonogenesis of Mesozoic rocks in the Blue Mountains of eastern Oregon and western Idaho. In Vallier, T. L., and Brooks, H. C. (Eds.), Geologic Implications of Paleozoic and Mesozoic Paleontology and Biostratigraphy, Blue Mountains Province, Oregon, Idaho and Washington. Geol. Surv. Prof. Pap. U.S., 1435:65-78.

Pessagno, E. A., Longoria, J., MacLeod, N., and Six, W., 1987. Studies of North American Jurassic Radiolaria: Part I, Upper Jurassic (Kimmeridgian-upper Tithonian) Pantanelliidae from the Taman Formation, east-central Mexico: tectonostratigraphic, chronostratigraphic, and phylogenetic implications. Spec. Publ. Cushman Found. Foraminiferal Res., 23:1-51.

Pessagno, E. A., and Whalen, P., 1982. Lower and Middle Jurassic Radiolaria (multicyrtid Nassellariina) from California, east-central Oregon and the Queen Charlotte Islands, B. C. Micropaleontology, 28:111-169.

Renz, G. W., 1974. Radiolaria from Leg 27 of the Deep Sea Drilling Project. In Veevers, J. J., Heirtzler, J. R., et al., Init. Repts. DSDP, 27: Washington (U.S. Govt. Printing Office), 769-841.

Ricou, L.-E., Besse, J., Marcoux, J., and Patriat, P., 1990. Un fit Gondwanien revise sur donnees pluridisciplinaires. C. R. Acad. Sci. Paris.

Riedel, W. R. and Sanfilippo, A., 1974. Radiolaria from the southern Indian Ocean, DSDP Leg 26. In Davies, T. A., Luyendyk, B. P., et al., 
Init. Repts. DSDP, 26: Washington (U.S. Govt. Printing Office), 771-814.

Rüst, D., 1885. Beitrage zur Kenntniss der fossilen Radiolarien aus Gesteinen des Jura. Palaeontographica, 31:269-321.

1898. Neue Beitrage zur Kenntniss der Fossilen Radiolarien aus Gesteinen des Jura und der Kreide. Palaeontographica, 45:1-67.

Sanfilippo, A., and Riedel, W. R., 1985. Cretaceous Radiolaria. In Bolli, H. M., Saunders, J. B., and Perch-Nielsen, K. (Eds.), Plankton Stratigraphy: Cambridge (Cambridge Univ. Press), 573-630.

Schaaf, A., 1981. Late Early Cretaceous Radiolaria from Deep Sea Drilling Project Leg 62. In Thiede, J., Vallier, T. L., et al., Init. Repts. DSDP, 62: Washington (U.S. Govt. Printing Office), 419-470.

, 1984. Les radiolaires du Crétacé inféreur et moyen: biologie et systématique. Sci. Geol. Mem., 75:1-189.

1985. Un nouveau canevas biochronologique du Crétacé inférieur et moyen: les biozones à radiolaires. Sci. Geol. Bull., 38:227269.

Spörli, K. B., and Aita, Y., 1988. Field Trip Guide to Waipapa Basement rocks, Kawakawa Bay, Auckland. Geol. Soc. N.Z. Misc. Publ., 39:128.

Spörli, K. B., Aita, Y., and Gibson, G. W., 1989. Juxtaposition of tethyan and non-tethyan mesozoic radiolarian faunas in melanges, Waipapa terrane, North Island, New Zealand. Geology, 17:753-756.

Squinabol, S., 1903. Le Radiolaire dei noduli selciosi nella Scaglia degli Euganei. Contribuzione I (Radiolaria from siliceous nodules of the Euganei shales). Riv. Ital. Paleontol., 9:105-151.

, 1914. Contributo alla conoscenza dei Radiolarii fossili del Veneto. Appendice-Di un genera di Radiolari caratteristico del Secondario (Contribution to the knowledge of fossil Radiolaria. Appendix-On a genus of Radiolaria characteristic of the Mesozoic). Mem. Ist. Geol. R. Univ. Padova, 2:249-306.

Steiger, T., 1987. Systematik, Stratigraphie und Palokologie der Radiolarien des Oberjura-Unterkreide-Grenzberiches im Osterhorn-Tirolikum (Nordliche kalkalpen, Salzburg und Bayern). Unpublished, $1-331$.

Suyari, K., 1986. Radiolarian assemblages from the Torinosu Group and the cherts of the North Subbelt of the Shimanto Belt. In Recent Progress of Research on Radiolarians and Radiolarian Terranes of Japan. News Osaka Micropaleontol., Spec. Vol., 7:245-254.

Suyari, K., and Kuwano, Y., 1986. Radiolarian age of the Torinosu group, Shikoku, Japan, Part 2. J. Sci., Univ. Tokushima, 19:37-43.
Tajika, J., and Iwata, K., 1983. Presence of Cretaceous radiolarians in Hidaka Supergroup, Maruseppu, Northeast Hokkaido. Chishitsugaku Zasshi, 89:535-538.

Taketani, Y., 1982. Cretaceous radiolarian biostratigraphy of the Urakawa and Obira areas, Hokkaido. Sci. Rep. Tohoku Univ., Ser. 2, 52:1-75.

Tan Sin Hok, 1927. Over de samenstelling en het onstaan van krijt-en mergel-gesteenten van de Molukken (On the composition and formation of chalk and marlstone of the Moluccas). Jaarb. Mijnwezen Nederl. Oost-Indie, Jaarg. 55, 1926:5-165.

Thurow, J., 1988. Cretaceous radiolarians of the North Atlantic Ocean: ODP Leg 103 (Sites 638, 640 and 641) and DSDP Legs 93 (Site 603) and 47B (Site 398). In Boillot, G., Winterer, E. L., et al., Proc. ODP. Sci. Results, 103: College Station, TX (Ocean Drilling Program), 379-418.

Thurow, J., and Kuhnt, W., 1986. Mid-Cretaceous of the Gibraltar Arch Area. In Summerhayes, C. P., and Shackleton, N. J. (Eds.), North Atlantic Palaeoceanography. Spec. Publ.-Geol. Soc. Am., 22:423445.

Tucholke, B. E., Vogt, P. R., et al., 1979. Init. Repts. DSDP, 43: Washington (U.S. Govt. Printing Office).

Vishnevskaya, V.S., 1988. O vozmoshnostyakh rascheleniya yursko-paleotsenovykh bulkanogenno-kremnistykh formatsii severo-zapadnogo obramleniya Pacifiki ( $v$ predelakh SSSR) (On the possibility of subdividing the USSR siliceous volcanic formations surrounding the northwest Pacific). In Pushcharovskii, Y. M. (Ed.), Ocherkii po Geologii Kamchatki $i$ Koryakskogo Nagorya (Reports on the Geology of the Kamchatka and the Koryak Plateau). Moscow, USSR, Nauka, $8-15$.

Weissert, H., and Lini, A., in press. Ice age interludes during the time of Cretaceous greenhouse climate? In Muller, D., McKenzie, J. A., and Weissert, H. (Eds.), Controversies in Modern Geology: New York (Academic Press).

Yao, A., 1984. Subdivision of the Mesozoic complex in Kii-Yura area, southwest Japan and its bearing on the Mesozoic basin development in the southern Chichibu terrane. J. Geosci., Osaka City Univ., 27:41103.

Yao, A., Matsuoka, A., and Nakatani, T., 1982. Triassic and Jurassic radiolarian assemblages in southwest Japan. In Nakaseko, K. (Ed.), Proc. 1st Jpn. Radiolarian Symp., News Osaka Micropaleontol., Spec. Vol., 5:27-43.

Date of initial receipt: 12 September 1991

Date of acceptance: 8 October 1991

Ms 125B-127 


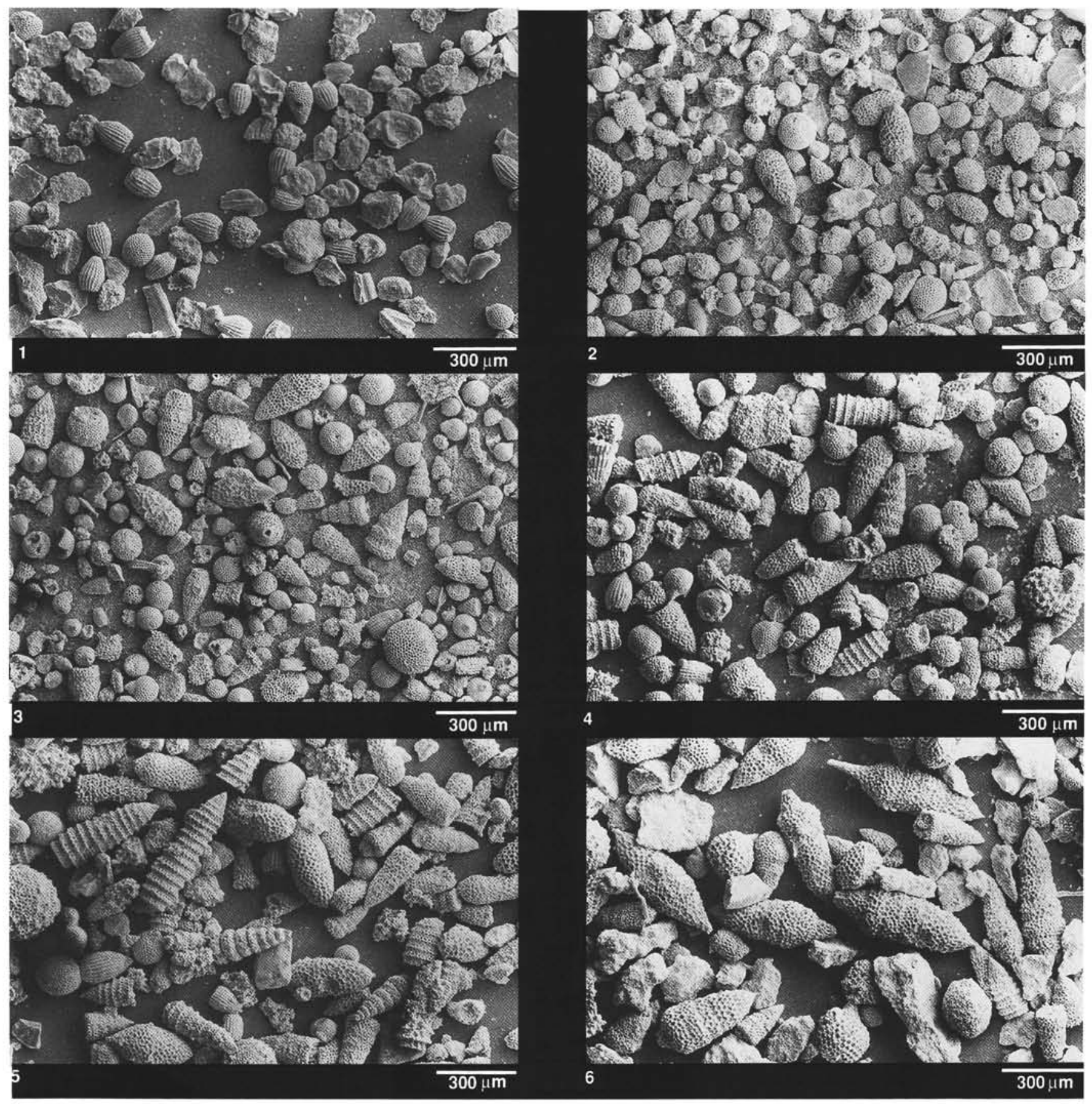

Plate 1. SEM photomicrographs of randomly strewn, entire residues $(42-500 \mathrm{~mm}$ ) of washed samples from Hole $765 \mathrm{C}$, Cores 59R to 54R (Berriasian to upper Hauterivian) showing rapidly changing radiolarian content through the section. Most radiolarians preserved as microcrystalline quartz. 1. Sample 123-765C-59R-2, 121-125 cm, "clay fauna", radiolarian assemblage dominated by Archaeodictyomitra brouweri s.l. and cryptocephalic and cryptothoracic nassellarians. Remaining particles are clay flakes and carbonate fragments. 2. Sample 123-765C-59R-2, 96-98 cm, lowest "sand fauna" radiolarian assemblage dominated by Cyrtocapsa(?) sp. aff. C. pseudacerra and Cyrtocapsa(?) sp. A. 3. Sample 123-765C-058R-5, 143-147 cm, "sand fauna", same species as (2). 4. Sample 123-765C-058R-2, 65-67 cm, "sand fauna" with common Parvicingula sp. B and Eusyringium sp. A. 5. Sample 123-765C-57R-4, 51-53 cm, "sand fauna" dominated by Parvicingula sp. D and Pseudoeucyrtis sp. A. 6. Sample 123-765C-54R-CC, "sand fauna" dominated by Pseudoeucyrtis sp. B and Pseudoeucyrtis sp. C. 


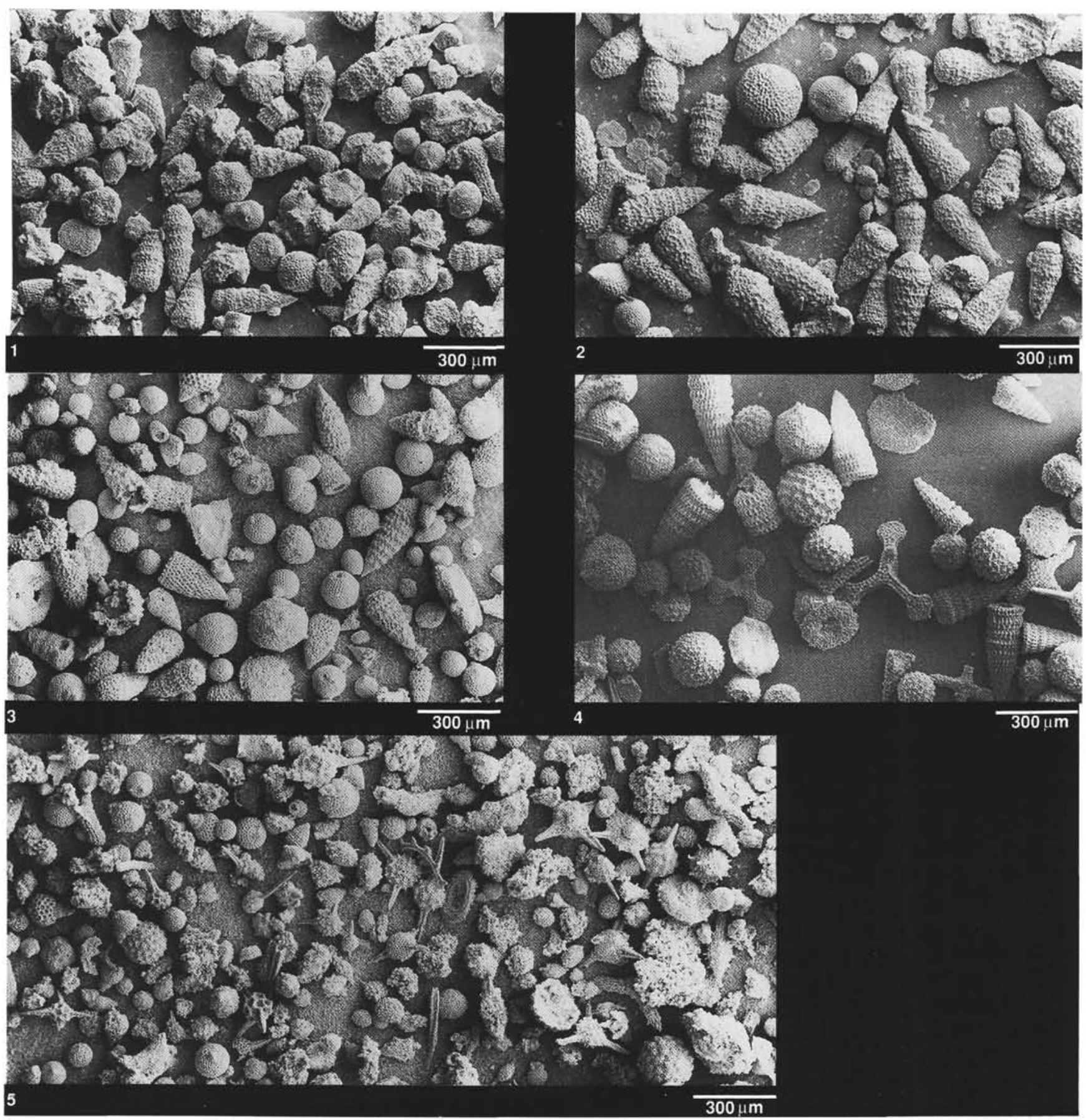

Plate 2. SEM photomicrographs of randomly strewn, entire residues $(42-500 \mathrm{~mm}$ ) of washed samples from Hole $765 \mathrm{C}$, Cores $53 \mathrm{R}-42 \mathrm{R}$ (upper Hauterivian-Aptian) showing rapidly changing radiolarian content through the section. Most radiolarians preserved as microcrystalline quartz. 1. Sample 123-765C-53R-5, 67-71 cm, "sand fauna" dominated by Eusyringium sp. C and cryptocephalic and cryptothoracic nassellarians. 2. Sample 123-765C-52R-3, 57-61 cm, "sand fauna" dominated by Eusyringium sp. D. 3. Sample 123-765C-50R-4, 108-112 cm, same species as (2). 4. Sample 123-765C-42R-3, 60-62 cm, "sand fauna" showing abundant parvicingulid sp. D, Praeconocaryomma sp. and the appearance of some Tethyan forms like Angulobracchia sp. and Paronaella sp. 5. Sample BO 566.50, hydrochloric acid residue of radiolarian-bearing pelagic limestone of the Maiolica Formation, Torrente Bosso, Umbria, central Italy. Age: late Hauterivian (same age as Cores $123-765 \mathrm{C}-54 \mathrm{R}$ to $-52 \mathrm{R}$ ). Note much more diverse Tethyan assemblage, rich in spinose spumellarians, pantanellids, hagiastrids, etc. 


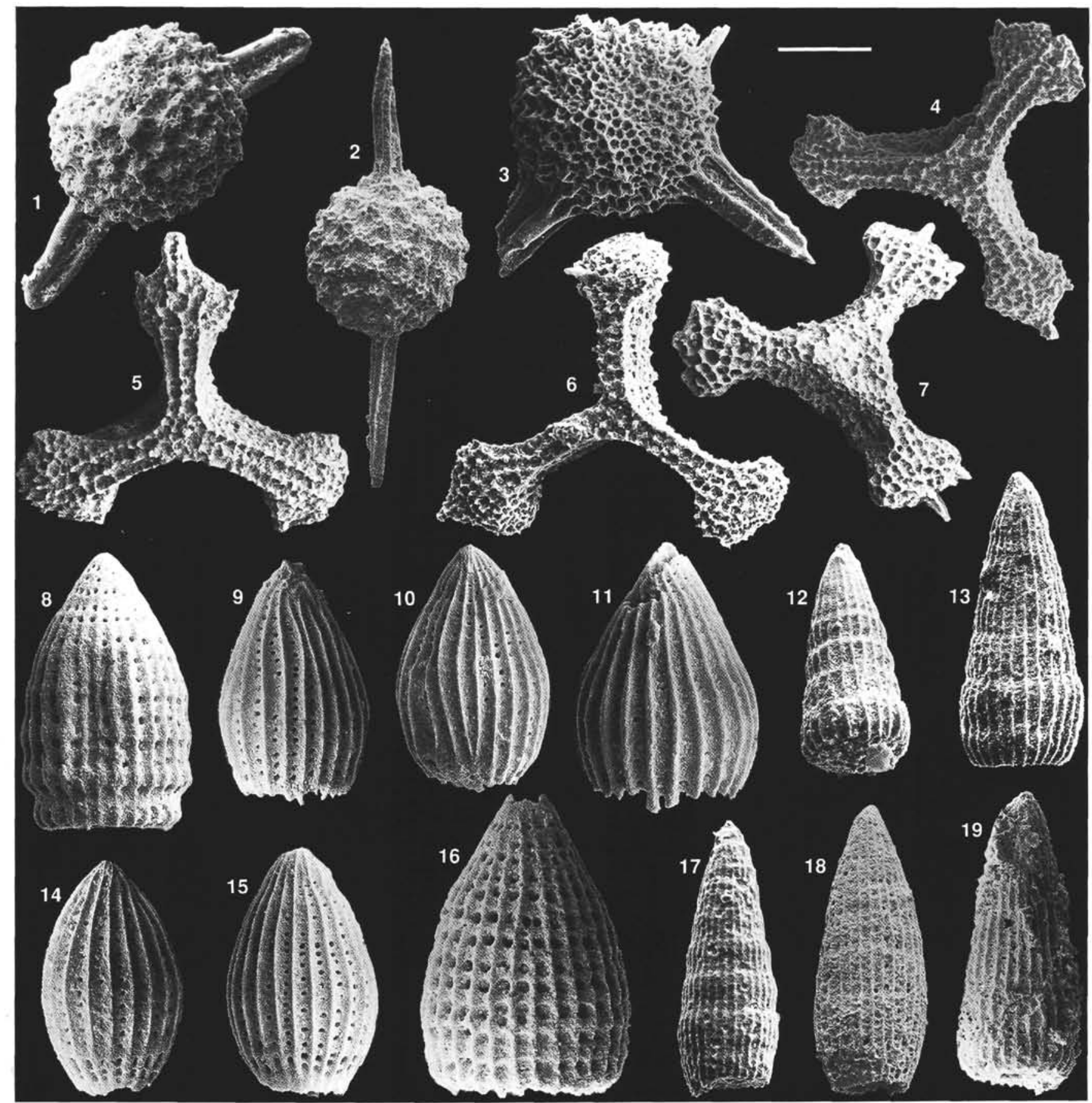

Plate 3. SEM photomicrographs of Neocomian (Berriasian-Aptian) radiolarians from Hole $765 \mathrm{C}$, Cores $62 \mathrm{R}-42 \mathrm{R}$. Magnification $\times 150(\mathrm{scale}$ bar $=$ $100 \mathrm{~mm}$ ) if not otherwise indicated. Scale bar $=67 \mathrm{~mm}$ for $\times 225$. Taxon names are preceded by taxon number. The SEM micrograph number $(90 / \mathrm{XXXX})$ is given for each illustration. 1. 3090 Acaeniotyle diaphorogona Foreman. Sample 123-765C-51R-3, 6-9 cm, 90/1173. 2. 3092 Acaeniotyle umbilicata Rüst. Sample 123-765C-52R-2, 68-71 cm, 90/1222. 3. 6135 Acaeniotyle(?) sp. A. Sample 123-765C-59R-2, 96-98 cm, 90/0490. 4. 5223 Angulobracchia(?) media Steiger. Sample 123-765C-45R-2, 26-28 cm, 90/1020. 5, 6. 3607 Angulobracchia spp. 5. Sample 123-765C-45R-2, 26-28 cm, 90/1019. (6) Sample 123-765C-42R-3, 140-150 cm, 90/0924. (7) 3911 Angulobracchia(?) sp. A. Sample 123-765C-42R-3, 140-150 cm, 90/1130. 8. 5602 Archaeodictyomitra sp. aff. A. apiarium Rüst. Sample 123-765C-59R-2, 121-125 cm, 90/0366 x225. 9, 10. 5601 Archaeodictyomitra brouweri s.l. Tan. Sample 123-765C-59R-2, 121-125 cm, (9) 90/0337 x225; (10): 90/0372 ×225. 11. 5606 Archaeodictyomitra brouweri typica Tan. Sample 123-765C59R-2, 121-125 cm, 90/0391 x225. 12, 13, 17-19. 5626 Archaeodictyomitra spp. slender group. (12 13): Sample 123-765C-53R-5, 67-71 cm, (12): 90/0859; (13): 90/0861. (17): Sample 123-765C-42R-3, 60-62 cm, 90/0965; (18): Sample 123-765C-52R-2, 68-71 cm, 90/1216. (19): Sample 123-765C-62R-1, 53-56 cm, 90/0267. 14, 15. 5604 Archaeodictyomitra brouweri alfa Tan. Sample 123-765C-59R-2, 121-125 cm (14): 90/0323 x225; (15): 90/0375 x225. 16. 5603 Archaeodictyomitra sp. A. Sample 123-765C-59R-2, 121-125 cm, 90/0353 x225. 


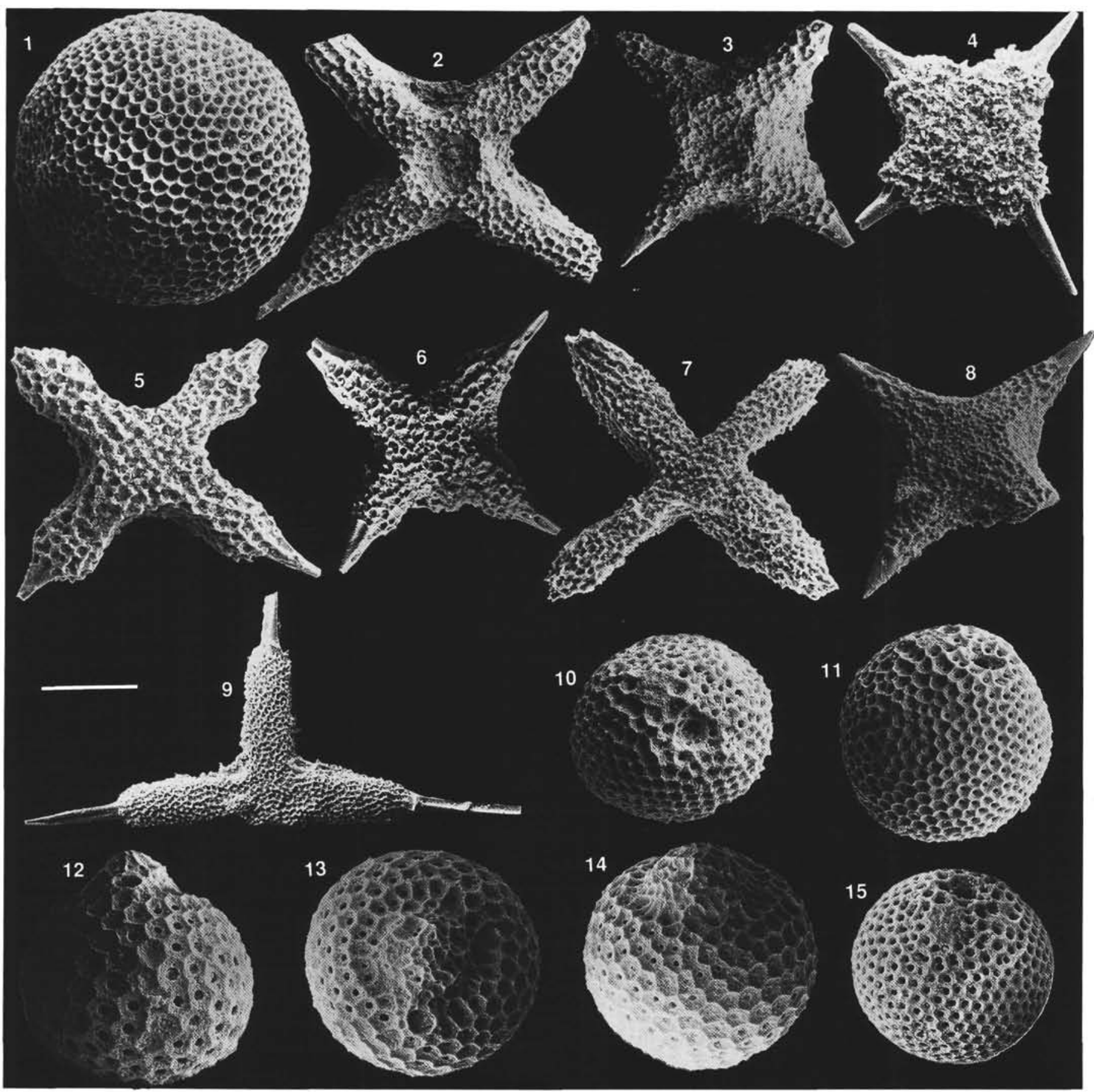

Plate 4. SEM photomicrographs of Neocomian (Berriasian-Aptian) radiolarians from Hole $765 \mathrm{C}$, Cores $62 \mathrm{R}-42 \mathrm{R}$. Magnification $\times 150(\mathrm{scale}$ bar $=$ $100 \mathrm{~mm}$ ) if not otherwise indicated. Scale bar $=67 \mathrm{~mm}$ for $\times 225 ; 200 \mathrm{~mm}$ for $\times 75$. Taxon names are preceded by taxon number. The SEM micrograph number $(90 / \mathrm{XXXX})$ is given for each illustration. 1. 6136 Cenosphaera spp. Sample 123-765C-59R-2, 96-98 cm, 90/0511. 2, 3. 5204 Crucella cachensis Pessagno. Sample 123-765C-45R-1, 76-80 cm, (2):90/1069. (3):90/1067. 4. 6140 Crucella sp. aff. C. espartoensis Pessagno. Sample 123-765C-42R-3, 60-62 cm, 90/0931. 5-9. 3619 Crucella spp. 5. Sample 123-765C-42R-3, 60-62 cm, 90/0914. (6) Sample 123-765C-42R-3, 140-150 cm, 90/1151. (7) Sample 123-765C-59R-2, 96-98 cm, 90/0467. (8) Sample 123-765C-51R-3, 6-9 cm, 90/0931. (9) Sample 123-765C-50R-5, 144-148 cm, 90/1291 x75. 10, 11, 15. 6143 Cryptamphorella sp. A. All x225. (10) Sample 123-765C-59R-2, 121-125 cm, 90/0330. (1), (15) Sample 123-765C-62R-1, 53-56 cm, 90/0300, 90/0301. 12-14. 6134 Cryptamphorella sp. aff. C. macropora Dumitrica. All x225. Sample 123-765C-59R-2, 121-125 cm. (12, 13) Same specimen: 90/0358, 90/0357, (14) 90/0357. 


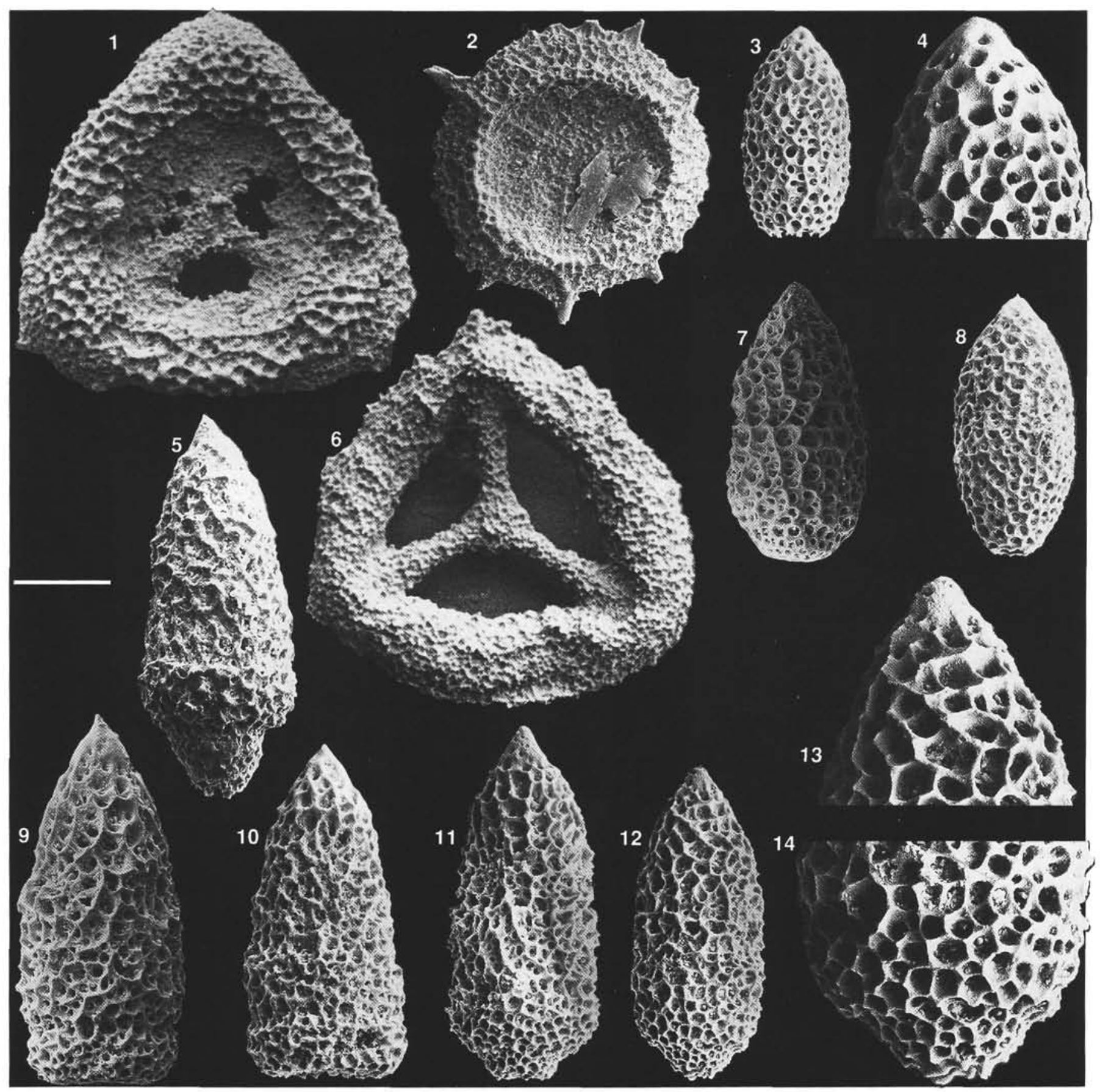

Plate 5. SEM photomicrographs of Neocomian (Berriasian-Aptian) radiolarians from Hole $765 \mathrm{C}$, Cores $62 \mathrm{R}-42 \mathrm{R}$. Magnification $\times 150(\mathrm{scale}$ bar $=$ $100 \mathrm{~mm}$ ) if not otherwise indicated. Scale bar $=50 \mathrm{~mm}$ for $x 300$. Taxon names are preceded by taxon number. The SEM micrograph number $(90 / X X X X)$ is given for each illustration. 1, 6.5261 Cyclastrum infundibuliforme Rüst. (1) Sample 123-765C-45R-2, 26-28 cm, 90/1035. 2. Sample 123-765C-43R-1, 76-80 cm, 90/1048. 2. 5903 Cyclastrum sp. A. Sample 123-765C-51R-3, 6-9 cm, 90/1187, x75. 3, 4, 7, 8. 5613 Cyrtocapsa(?) sp. aff. C. pseudacerra Tan. (3, 4) Sample 123-765C-59R-2, 96-98 cm, (3) 90/0487, (4) Close-up of proximal portion, same specimen as (3) 90/1338, x300. (7) Sample 123-765C-62R-1, 53-56 cm, 90/0265. (8) Sample 123-765C-59R-1, 123-126 cm, 90/0566. 5, 9-14. 5612 Cyrtocapsa(?) sp. A. (5) Sample 123-765C58R-2, 65-67 cm, 90/0738. Note development of terminal appendage on younger specimens. (9) Sample 123-765C-62R-1, 53-56 cm, 90/0260. (10) Sample 123-765C-59R-1, 123-126 cm, 90/0591. (11, 12) Sample 123-765C-59R-2, 96-98 cm, 90/0472, 90/0475. (13, 14) Same specimen as 12, close-ups of proximal and distal portions showing polygonal pore frames and terminal appendage. 90/1335, 90/1337. both x300. 


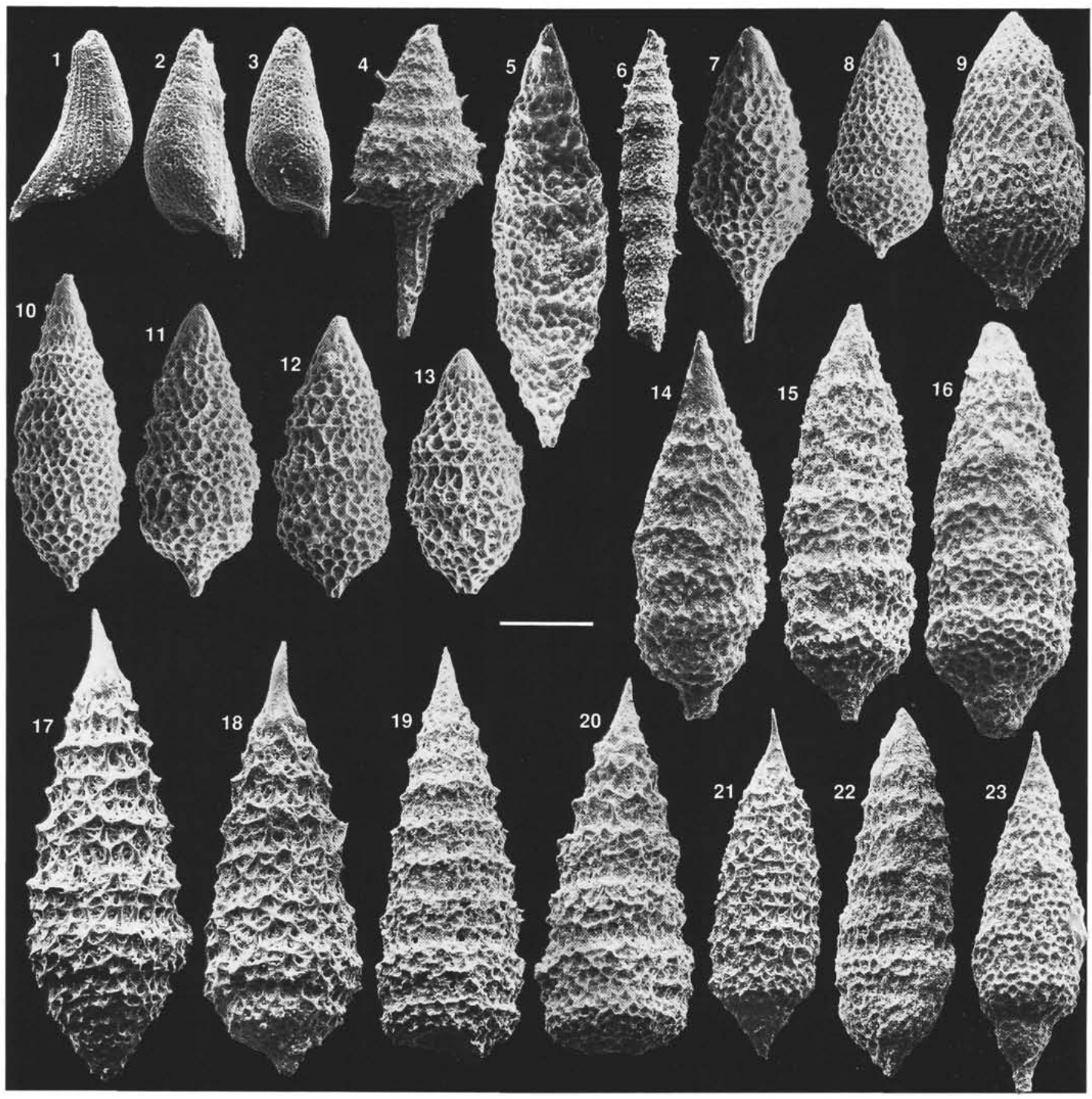

Plate 6. SEM photomicrographs of Neocomian (Berriasian-Aptian) radiolarians from Hole $765 \mathrm{C}$, Cores $62 \mathrm{R}-42 \mathrm{R}$. Magnification $\times 150(\mathrm{scale}$ bar $=$ $100 \mathrm{~mm}$ ) if not otherwise indicated. Taxon names are preceded by taxon number. The SEM micrograph number $(90 / \mathrm{XXXX})$ is given for each illustration. 1-3.5620 Eucyrtis columbaria Renz. (1) Sample 123-765C-50R-5, 144-148 cm, 90/1302. (2, 3) Sample 123-765C-42R-3, 60-62 cm, 90/0959, 90/0960. 4. 5407 Eucyrtis hanni Tan. Sample 123-765C-51R-3, 6-9 cm, 90/1177. 5. 5611 Eucyrtis micropora Squinabol. Sample 123-765C-53R-5, 67-71 cm, 90/0868. 6. 5610 Eucyrtis tenuis Rüst. Sample 123-765C-52R-2, 68-71 cm, 90/1232. 7-9. 5614 Eusyringium sp. A. (7, 8) Sample 123-765C-59R-2, 96-98 cm, 90/0455, 90/466. (9) Sample 123-765C-52R-2, 68-71 cm, 90/1237. 10-13. 5640 Eusyringium sp. B. Sample 123-765C-59R-2, 96-98 cm, 90/0453, 90/0446, 90/0465, 90/0462. 14-16, 22, 23. 6123 Eusyringium sp. C. $(14-16,23)$ Sample $123-765 C-53 R-5,67-71 \mathrm{~cm}, 90 / 0886,90 / 0895$, 90/0897, 90/0906. (22) Sample 123-765C-54R-4, 21-24 cm, 90/1249. 17-21. 5619 Eusyringium sp. D. (17, 18) Sample 123-765C-50R-5, 144-148 cm, 90/1275, 90/1281. (19, 20) Sample 123-765C-52R-2, 68-71 cm, 90/1234, 90/1224. (21) Sample 123-765C-51R-3, 6-9 cm, 90/01167. 


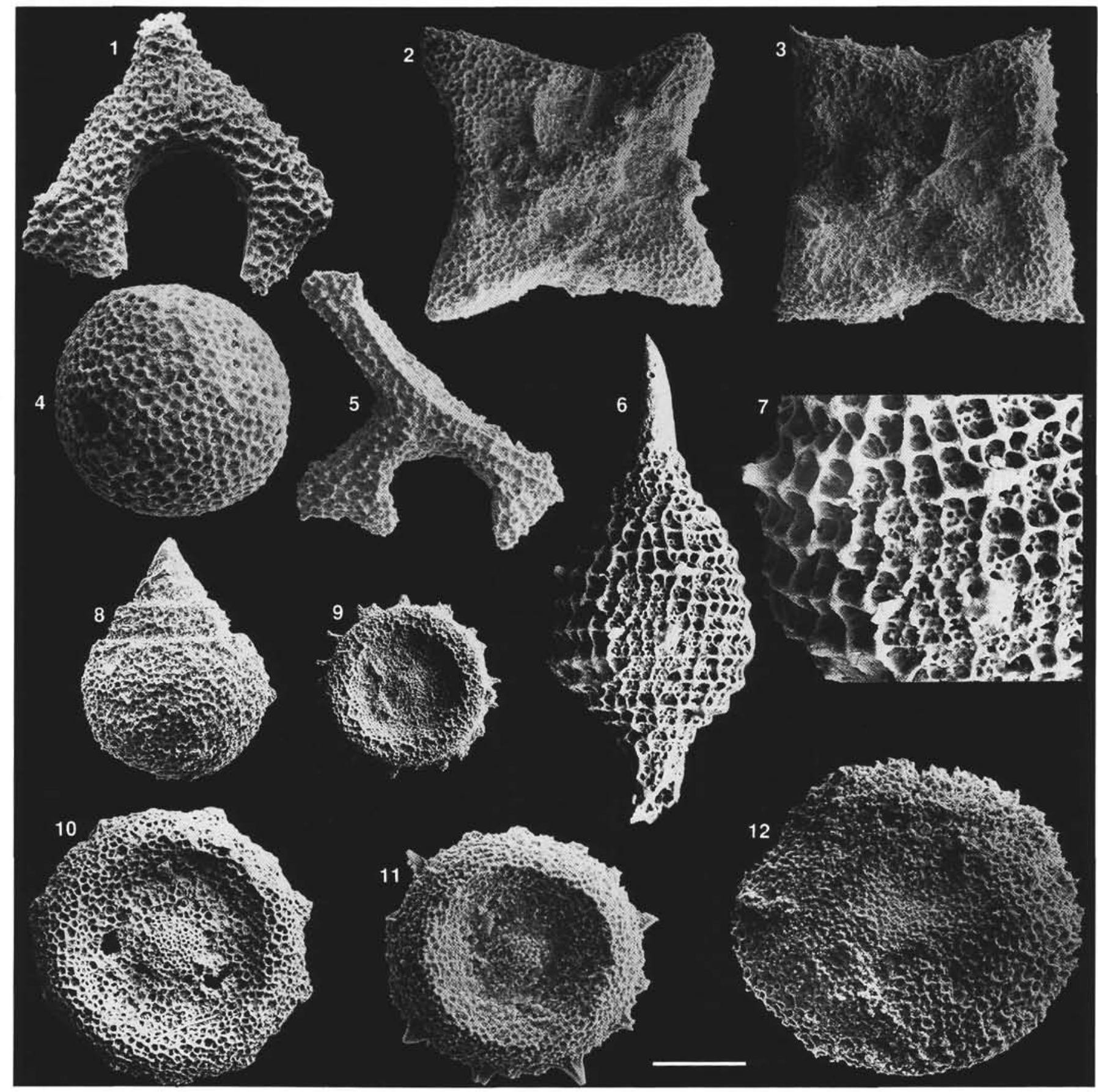

Plate 7. SEM photomicrographs of Neocomian (Berriasian-Aptian) radiolarians from Hole $765 \mathrm{C}$, Cores $62 \mathrm{R}-42 \mathrm{R}$. Magnification $\times 150(\mathrm{scale}$ bar $=$ $100 \mathrm{~mm}$ ) if not otherwise indicated. Scale bar $=200 \mathrm{~mm}$ for $\times 75,67 \mathrm{~mm}$ for $\times 225$, and $50 \mathrm{~mm}$ for $\times 300$. Taxon names are preceded by taxon number. The SEM micrograph number (90/XXXX) is given for each illustration. 1.3112 Foremanella diamphidia diamphidia Foreman. Sample 123-765C-50R-5, 144-148 cm, 90/1290. 2, 3. 6139 Histiastrum cruciferum Lipman. Sample 123-765C-51R-3, 6-9 cm, 90/1193, 90/1192. 4. 5125 Holocryptocanium barbui barbui Dumicrita. Sample 123-765C-62R-1, 53-56 cm, 90/0256, x225. 5. 3111 Foremanella diamphidia hipposidericus Foreman. Sample 123-765C-45R-2, 26-28 cm, 90/1022 , 6, 7.3162 Mirifusus chenodes Renz. Sample 123-765C-42R-3, 140-150 cm, 90/1088. (6) Same specimen, close-up of wall showing inner layer with fine hexagonal meshwork, 90/1312, x300. 8. 3202 Obesacapsula verbana Parona. Sample 123-765C-58R-3, 89-93 $\mathrm{cm}, 90 / 0615, x 75.9,10.5274$ Orbiculiforma railensis Pessagno. (9) Sample 123-765C-50R-5, 144-148 cm, 90/1295, x75. (10) Sample 123-765C-42R-3, 140-150 cm, 90/1082. 11, 12. 3665 Orbiculiforma spp. 11. Sample 123-765C-42R-3, 60-62 cm, 90/0942. (12) Sample 123-765C-54R-CC, 90/0822. 


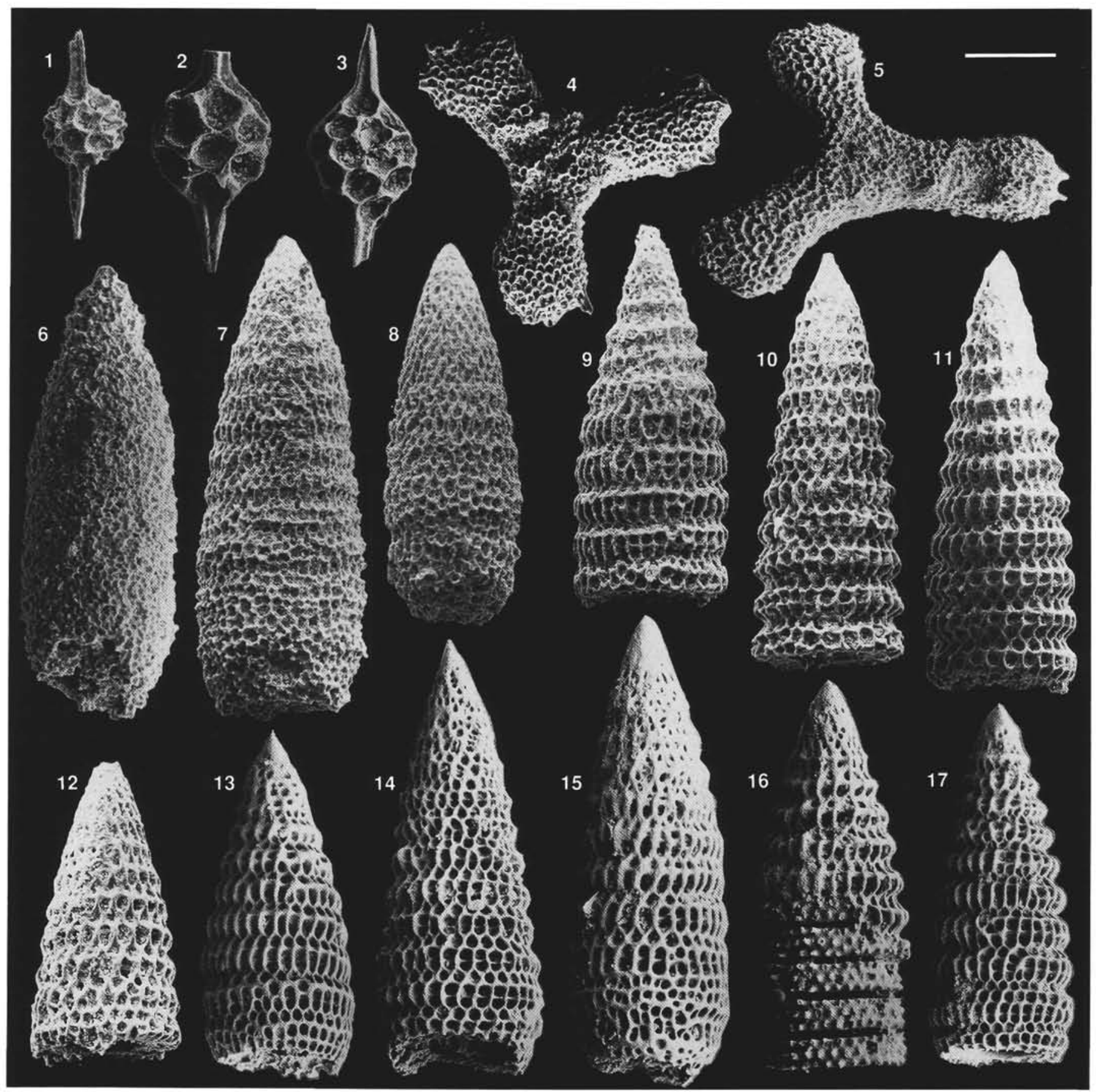

Plate 8. SEM photomicrographs of Neocomian (Berriasian-Aptian) radiolarians from Hole 765C, Cores $62 \mathrm{R}-42 \mathrm{R}$. Magnification $\times 150(\mathrm{scale}$ bar $=$ $100 \mathrm{~mm})$. Taxon names are preceded by taxon number. The SEM micrograph number (90/XXXX) is given for each illustration. 1. 5065 Pantanellium squinaboli cantuchapai Pessagno and Macleod. Sample 123-765C-45R-2, 26-28 cm, 90/1024. 2, 3. 5607 Pantanellium squinaboli squinaboli Tan. (2) Sample 123-765C-59R-2, 96-98 cm, 90/0494. (3) Sample 123-765C-45R-1, 76-80 cm, 90/1060, 4. 5186 Paronaella(?) sp. A. Sample 123-765C-59R-2, 96-98 cm, 90/0493. 5. 3671 Paronaella sp. Sample 123-765C-50R-5, 144-148 cm, 90/1286. 6. 5637 Parvicingula(?) malleola Aliev. Sample 123-765C-45R-2, 26-28 cm, 90/1026. 7, 8. 6127 Parvicingulid sp. A. Sample 123-765C-45R-2, 26-28 cm, 90/0986, 90/1014. 9-11. 6126 Parvicingulid sp. D. Sample 123-765C-42R-3, 60-62 cm, 90/0966, 90/0950, 90/0937. 12. 6125 Parvicingulid sp. B. Sample 123-765C-42R-3, 60-62 cm, 90/0919. 13-17. 6128 Parvicingulid sp. C. Sample $123-765 C-42 R-3,140-150 \mathrm{~cm}, 90 / 1147,90 / 1079,90 / 1071,90 / 1075,90 / 1143$. (16) Note three rows of pores per segment in hexagonal arrangement apparent on inner mold. External stricture is placed below segmental division at top row of pores. 


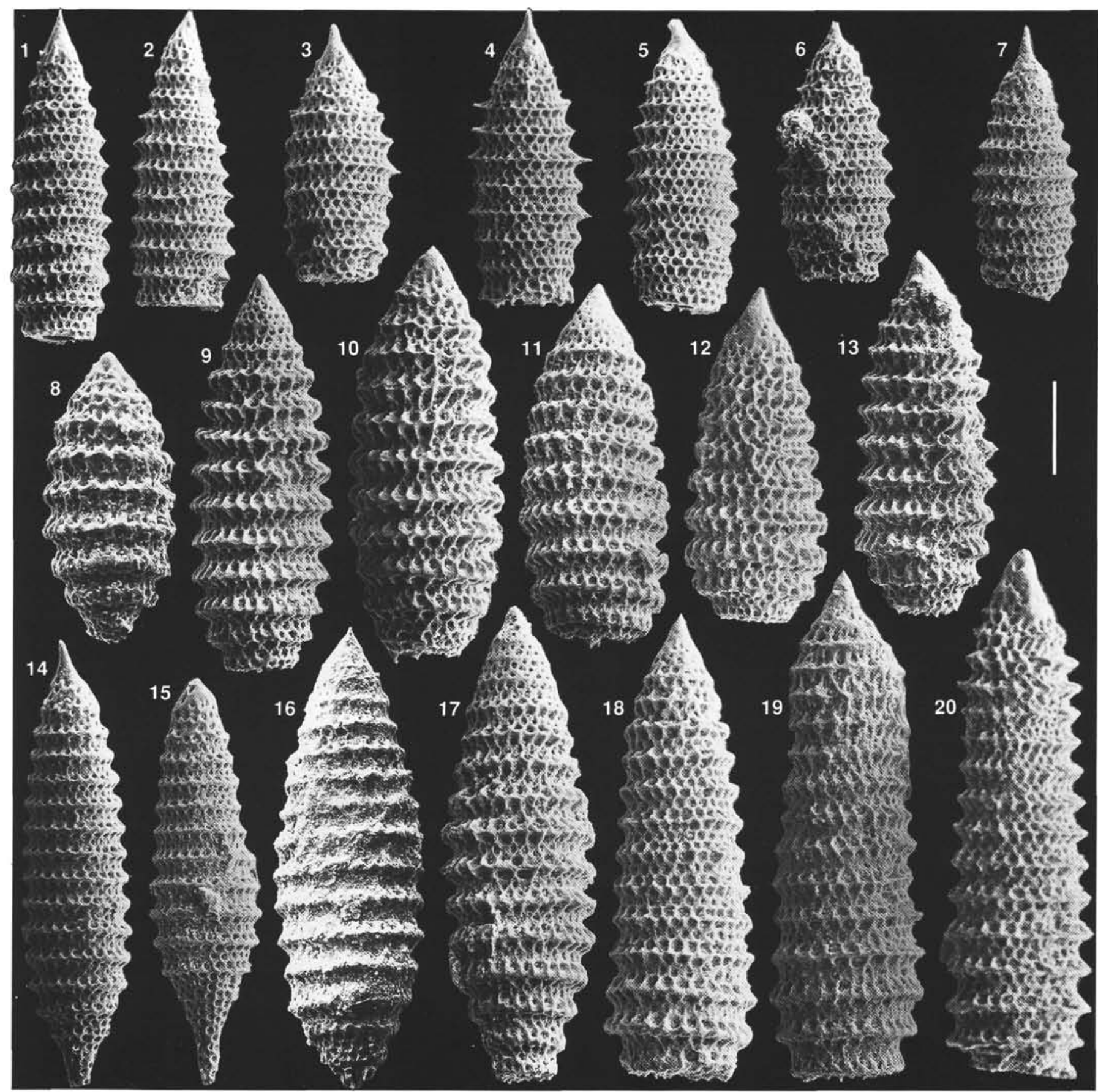

Plate 9. SEM photomicrographs of Neocomian (Berriasian-Aptian) radiolarians from Hole $765 \mathrm{C}$, Cores $62 \mathrm{R}-42 \mathrm{R}$. Magnification $\times 150(\mathrm{scale}$ bar $=$ $100 \mathrm{~mm}$ ). Taxon names are preceded by taxon number. The SEM micrograph number (90/XXXX) is given for each illustration. 1-4. 5633 Parvicingula sp. A. (1) Sample 123-765C-59R-1, 123-126 cm, 90/0543. (2-4) Sample 123-765C-59R-2, 96-98 cm, 90/0408, 90/0422, 90/0428. 5-7. 5631 Parvicingula sp. C. Sample 123-765C-59R-2, 96-98 cm, 90/0422, 90/0424, 90/0423. 8. 5635 Parvicingula sp. F. Sample 123-765C-58R-3, 89-93 cm, 90/0633. 9-13, 16, 17. 5608 Parvicingula sp. B. (9-12) Sample 123-765C-58R-3, 89-93 cm, 90/0644, 90/0625, 90/0647, 90/0665. (13) Sample 123-765C-54R-CC, 90/0834. (16) Sample 123-765C-54R-4, 21-24 cm, 90/1254. (17) Sample 123-765C-58R-3, 89-93 cm, 90/0646. 14, 15. 5609 Parvicingula sp. E. Sample 123-765C-59R-2, 96-98 cm, 90/0411, 90/0410, 18-20. 5634 Parvicingula sp. D. Sample 123-765C-57R-4, 51-53 cm, 90/0686, 90/0683, 90/0685. 


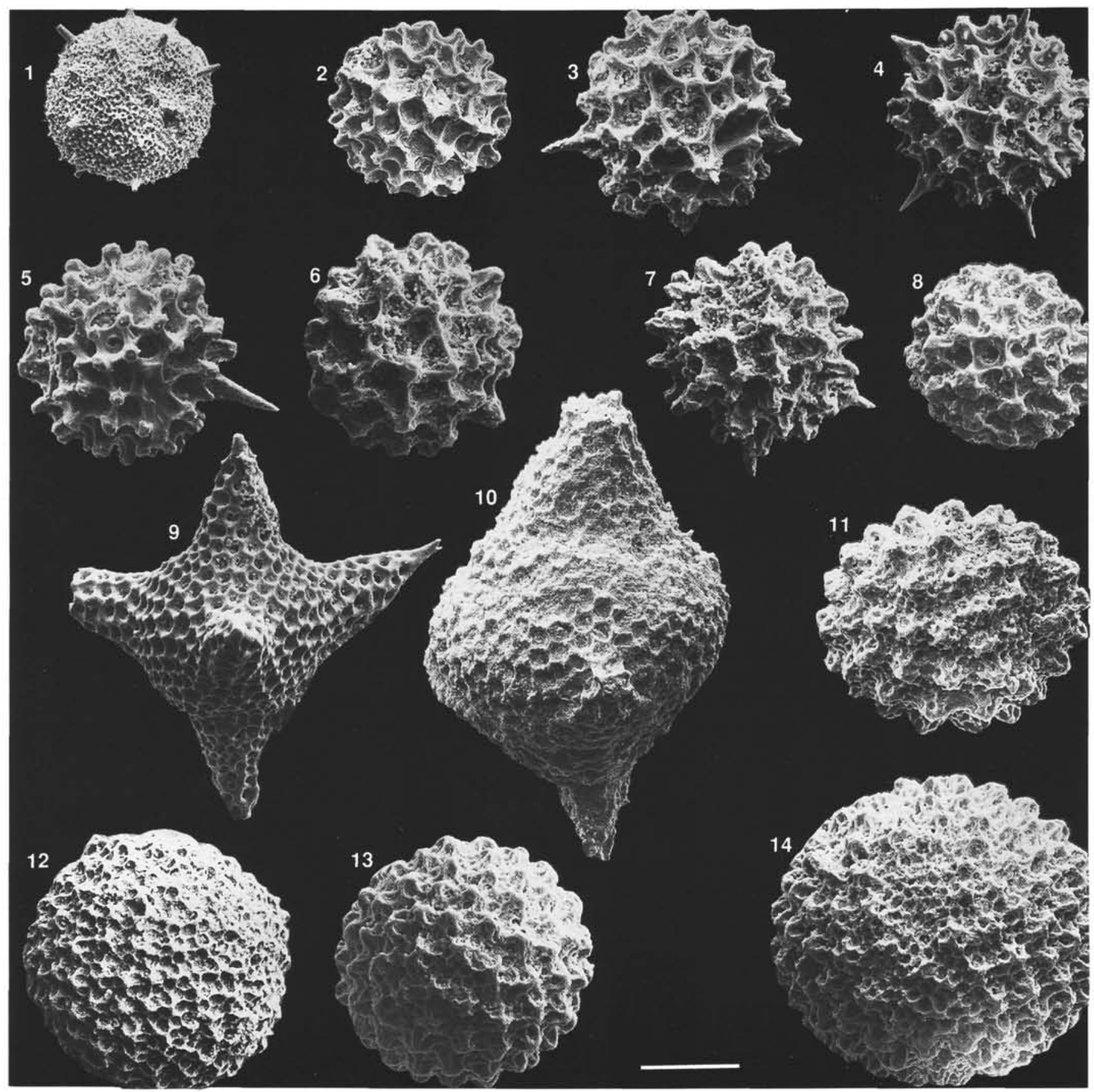

Plate 10. SEM photomicrographs of Neocomian (Berriasian-Aptian) radiolarians from Hole $765 \mathrm{C}$, Cores $62 \mathrm{R}-42 \mathrm{R}$. Magnification $\times 150(\mathrm{scale}$ bar $=$ $100 \mathrm{~mm})$. Taxon names are preceded by taxon number. The SEM micrograph number (90/XXXX) is given for each illustration. 1. 5287 Patellula sp. A. Sample 123-765C-59R-1, 123-126 cm, 90/0583. 2-8. 5639 Praeconocaryomma(?) sp. A. (2) Sample 123-765C-59R-2, 96-98 cm, 90/0523. (3-6) Sample 123-765C-59R-1, 123-126 cm, 90/0557, 90/0558, 90/0559, 90/5560. (7, 8) Sample 123-765C-58R-3, 89-93 cm, 90/0639, 90/0667. 9. 3171 Podocapsa amphitreptera Foreman. Sample 123-765C-58R-5, 143-147 cm, 90/0603. 10. 5623 Podocapsa sp. A. Sample 123-765C-54R-4, 21-24 cm, 90/1243. 11, 14. 6124 Praeconocaryomma sp. aff. P. prisca Pessagno. (11) Sample 123-765C-54R-CC, 90/0824. (14) Sample 123-765C-57R-1, 67-70 cm, 90/0785. 12, 13. 3681 Praeconocaryomma spp. 12. Sample 123-765C-42R-3, 140-150 cm, 90/1087. (13) Sample 123-765C-42R-3, 60-62 cm, 90/0922. 


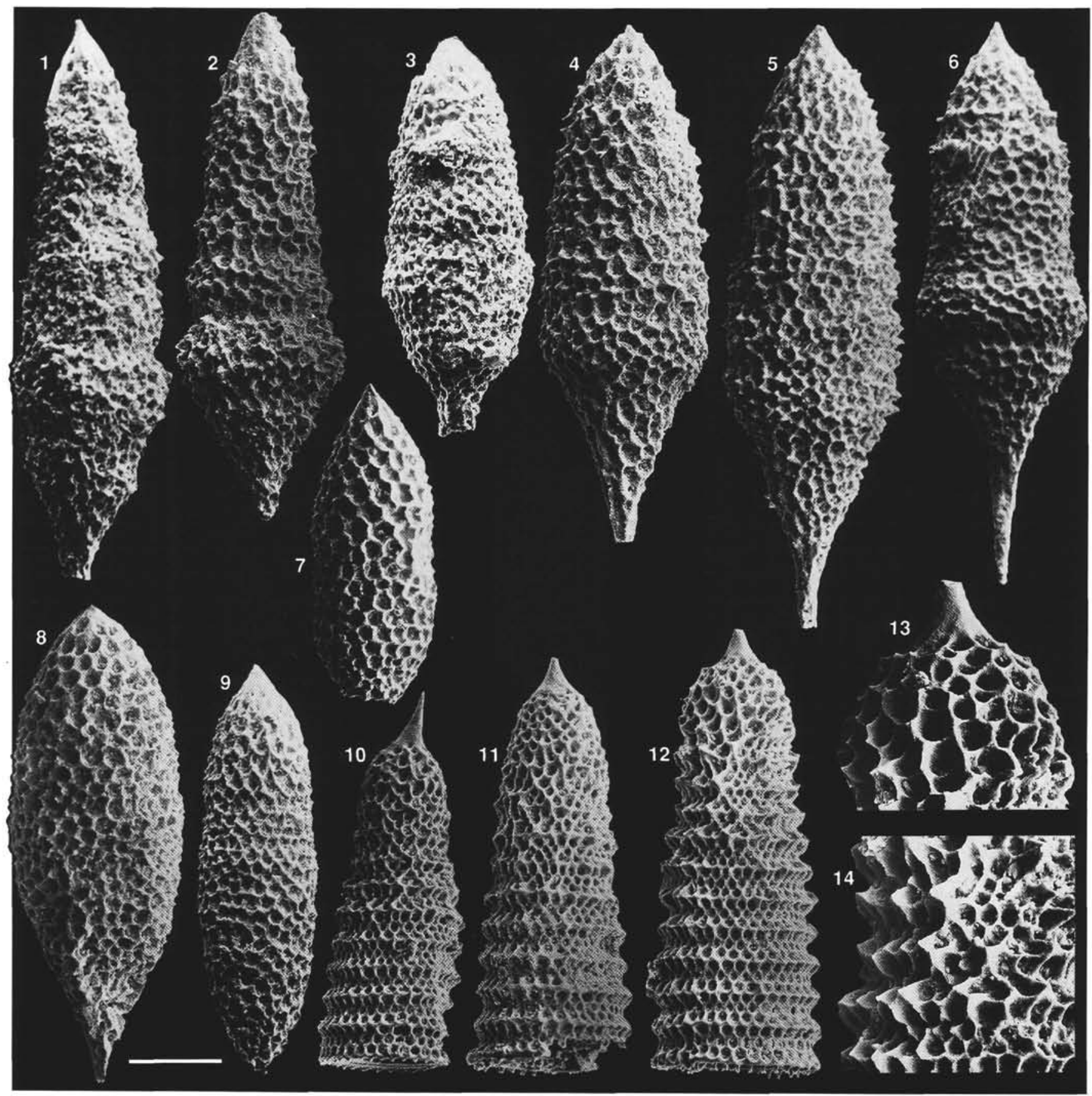

Plate 11. SEM photomicrographs of Neocomian (Berriasian-Aptian) radiolarians from Hole $765 \mathrm{C}$, Cores $62 \mathrm{R}-42 \mathrm{R}$. Magnification $\times 150(\mathrm{scale}$ bar $=$ $100 \mathrm{~mm}$ ) if not otherwise indicated. Scale bar $=50 \mathrm{~mm}$ for $\mathrm{x} 300$. Taxon names are preceded by taxon number. The SEM micrograph number ( $90 / X X X X)$ is given for each illustration. 1, 2. 5615 Pseudoeucyrtis sp. C. Sample 123-765C-54R-CC, 90/0826, 90/0820. 3-6. 5617 Pseudoeucyrtis sp. B. (3) Sample 123-765C-58R-2, 65-67 cm, 90/0733. (4-6) Sample 123-765C-54R-CC, 90/0808, 90/0797, 90/0811. 7-9. 5618 Pseudoeucyrtis sp. A. (7) Sample 123-765C-57R-1, 67-70 cm, 90/0689. (8) Sample 123-765C-57R-4, 51-53 cm, 90/0698. (9) Sample 123-765C-58R-2, 65-67 cm, 90/0722. 10-14. 5632 Ristola sp. A. Sample 123-765C-59R-2, 96-98 cm, 90/0443, 90/0440, 90/0438 (13, 14) Same specimen as (12). Close-ups of proximal dome-shaped and median parts showing coarse polygonal pore frames superimposed on the hexagonally arranged three rows of pores per segment, $90 / 1327,90 / 1328$, both $\times 300$. 


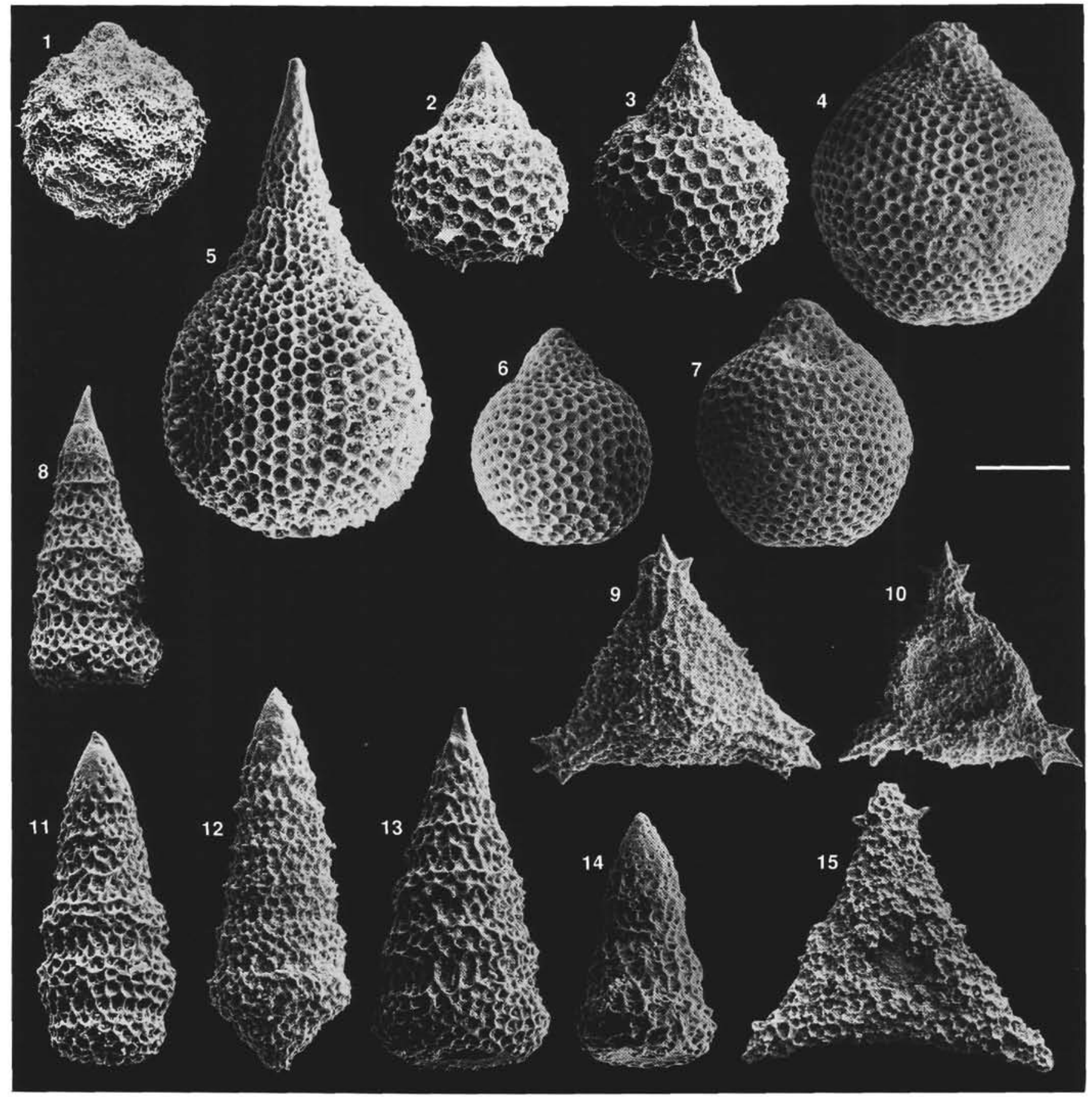

Plate 12. SEM photomicrographs of Neocomian (Berriasian-Aptian) radiolarians from Hole 765C, Cores $62 \mathrm{R}-42 \mathrm{R}$. Magnification $\times 150(\mathrm{scale}$ bar $=$ $100 \mathrm{~mm}$ ) if not otherwise indicated. Scale bar $=200 \mathrm{~mm}$ for $\times 75,67 \mathrm{~mm}$ for $\times 225$. Taxon names are preceded by taxon number. The SEM micrograph number $(90 / X X X X)$ is given for each illustration. 1. 3203 Sethocapsa cetia Foreman. Sample 123-765C-58R-3, 89-93 cm, 90/0637, x75. 2, 3. 3062 Sethocapsa leiostraca Foreman. Sample 123-765C-54R-CC, 90/0799, 90/0800. 4. 5553 Sethocapsa orca Foreman. Sample 123-765C-59R-2, 121-125 $\mathrm{cm}, 90 / 0400, x 225.5$. 5544 Sethocapsa dorysphaeroides Neviani. Sample 123-765C-58R-5, 143-147 cm, 90/0614. 6. 6131 Sethocapsa sp. A. Sample 123-765C-59R-2, 121-125 cm, 90/0362. 7. 6129 Sethocapsa sp. B. Sample 123-765C-59R-2, 121-125 cm, 90/0370. 8, 11, 12. 6121 Spongocapsula(?) sp. B. (8) Sample 123-765C-58R-5, 143-147 cm, 90/0606. (11) Sample 123-765C-59R-1, 123-126 cm, 90/0575. (12) Sample 123-765C-54R-CC, 90/0833. 9, 10, 15. 5901 Spongotripus trigonus Rüst. Sample 123-765C-45R-2, 26-28 cm, 90/1030, 90/1029, 90/0998. 13, 14. 6122 Spongocapsula(?) sp. A. (13) Sample 123-765C-58R-3, 89-93 cm, 90/0629. (4) Sample 123-765C-59R-2, 96-98 cm, 90/0445. 


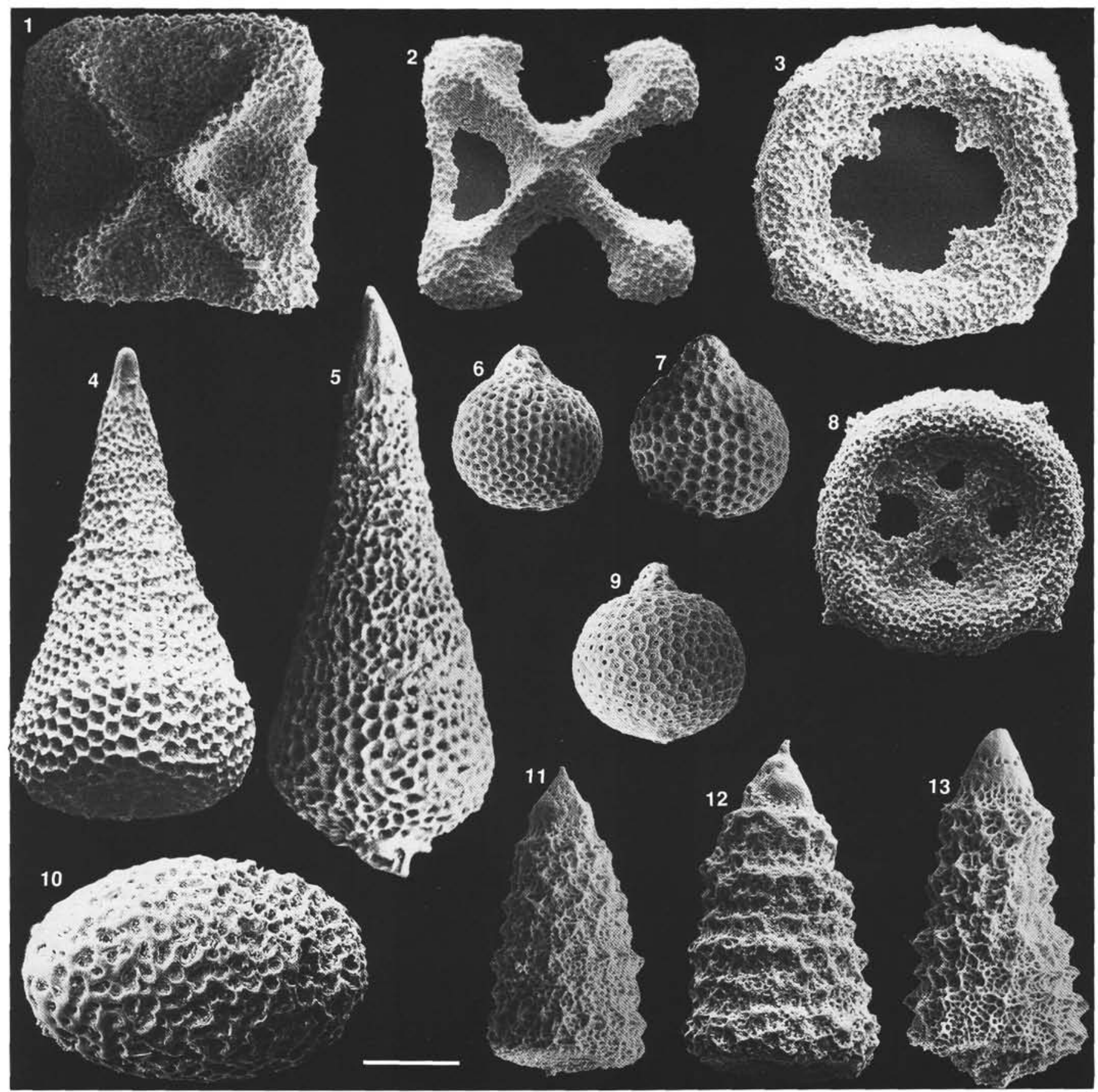

Plate 13. SEM photomicrographs of Neocomian (Berriasian-Aptian) radiolarians from Hole $765 \mathrm{C}$, Cores $62 \mathrm{R}-42 \mathrm{R}$. Magnification $\times 150(\mathrm{scale}$ bar $=$ $100 \mathrm{~mm}$ ) if not otherwise indicated. Scale bar $=67 \mathrm{~mm}$ for $\times 225$. Taxon names are preceded by taxon number. The SEM micrograph number $(90 / X X X X)$ is given for each illustration. 1, 2. 5902 Stephanastrum inflexum Rüst. Sample 123-765C-45R-2, 26-28 cm, 90/1032, 90/1031. 3, 8. 6138 Stephanastrum orbiculare Rüst. Sample 123-765C-42R-3, 60-62 cm, 90/0916, 90/0929. 4, 5. 5550 Stichocapsa perspicua Squinabol. (4) Sample 123-765C-50R-5, 144-148 cm, 90/1301. (5) Sample 123-765C-42R-3, 140-150 cm, 90/1083. 6, 7. 6130 Tricolocapsa sp. A. Sample 123-765C-62R-1, 53-56 cm, 90/0288, 90/0292, both x225. 9. 6132 Tricolocapsa sp. B. Sample 123-765C-62R-1, 53-56 cm, 90/0299. 10. 6137 Tripocalpis laboriosus Tan. Sample 123-765C-59R-2, 96-98 cm, 90/0503. 11-13. 3676 Xitus spp. (11, 12) Sample 123-765C-58R-3, 89-93 cm, 90/0654, 90/0622. 13. Sample 123-765C59R-2, 96-98 cm, 90/0457. 